\title{
HORREUMOK ÉS A GABONAFELDOLGOZÁS EMLÉKEI SAVARIÁBÓL
}

\author{
Balázs PÉTer - Bíró Szilvia - Csapláros Andrea - Hódi Attila - Sosztarits Ottó*
}

The study reviews our current knowledge on grain processing and granaries in Savaria based on the interpretation of the building inscription of a well-known horreum, with a focus on the provisioning of the late Roman army and the construction of horrea in the provinces during the 4th century.

Keywords: horreum, late Roman period, grain supply (annona militaris), praefectus praetorio, grain processing

A cikk egy ismert horreum épitési feliratának értelmezése kapcsán foglalja össze a savariai gabonafeldolgozásra és raktárakra vonatkozó ismereteket, rávilágitva azokra a fontosabb összefüggésekre, amelyek a késő római hadsereg élelmiszer-ellátása, illetve a tartományok horreumépitése között a 4. században fennálltak.

Kulcsszavak: horreum, késő római korszak, gabonaellátás (annona militaris), praefectus praetorio, gabonafeldolgozás

\section{Bevezetés $^{1}$}

A gabona kiemelt fontossága a római korban különösen annak ismeretében igaz, hogy a hosszú távon tárolható élelmiszerek száma az ókorban véges. Kifejezetten így volt ez a városias környezetben, ahol az élóállat-teleltetést nem lehetett megoldani. Ezért azokon a településeken, ahol más élelmiszer nagy tömegben való tárolására korlátozott volt a lehetőség, a sózott hús mellett a gabona játszott meghatározó szerepet.

๑ A kézirat beérkezett: 2017. május 4. Függelék: 2017. május 15.

* Iseum Savariense Régészeti Múhely és Tárház. 9700 Szombathely, II. Rákóczi Ferenc utca 6-8.; iseumsavariense@gmail. com

1 Itt szeretnénk megköszönni Tóth Endrének a tanulmány elkészítése során nyújtott segítségét, Buócz Teréziának az ásatási eredményei felhasználásának lehetőségét; továbbá Derdák Ferenc, Szilasi Attila Botond, Kiss Tamás, Isztin Gyula közremúködését a grafikák és rajzok elkészítésében.
A különböző élelmiszerek raktározására, időszakos tárolására szolgáló épületek (horreumok) kezdenek megjelenni a városokban, katonai táborokban, villagazdaságokban és kisebb településeken, illetve funkciójukból fakadóan később már szerves részét képezték a kereskedelmi létesítményeknek (kikötóknek, kereskedelmi csomópontoknak) is. ${ }^{2}$

A következőkben elsősorban a városias környezetben előforduló horreumok elterjedését, topográfiai elhelyezkedését, kronológiáját vizsgáljuk, ennek során a szakirodalom által régóta ismert és hivatkozott savariai horreumot említó feliratot szeretnénk kontextusba helyezni. A fel-

2 A horreum kifejezés sokszor gabonatároló értelmezésben használatos, azonban fontos leszögezni, hogy a horreum általánosságban raktárat jelentett, ennek csak egyik aspektusa a gabonatároló, amelyet sokszor a granarium kifejezéssel illetnek. Lásd a továbbiakban: FIECHTER 1913, 2458-2460 (horreum); ORTH 1912, 1812-1813 (granarium); újabb összefoglaló az írásos forrásokkal: SALIDO DomínGUEZ 2011, 40-44. 


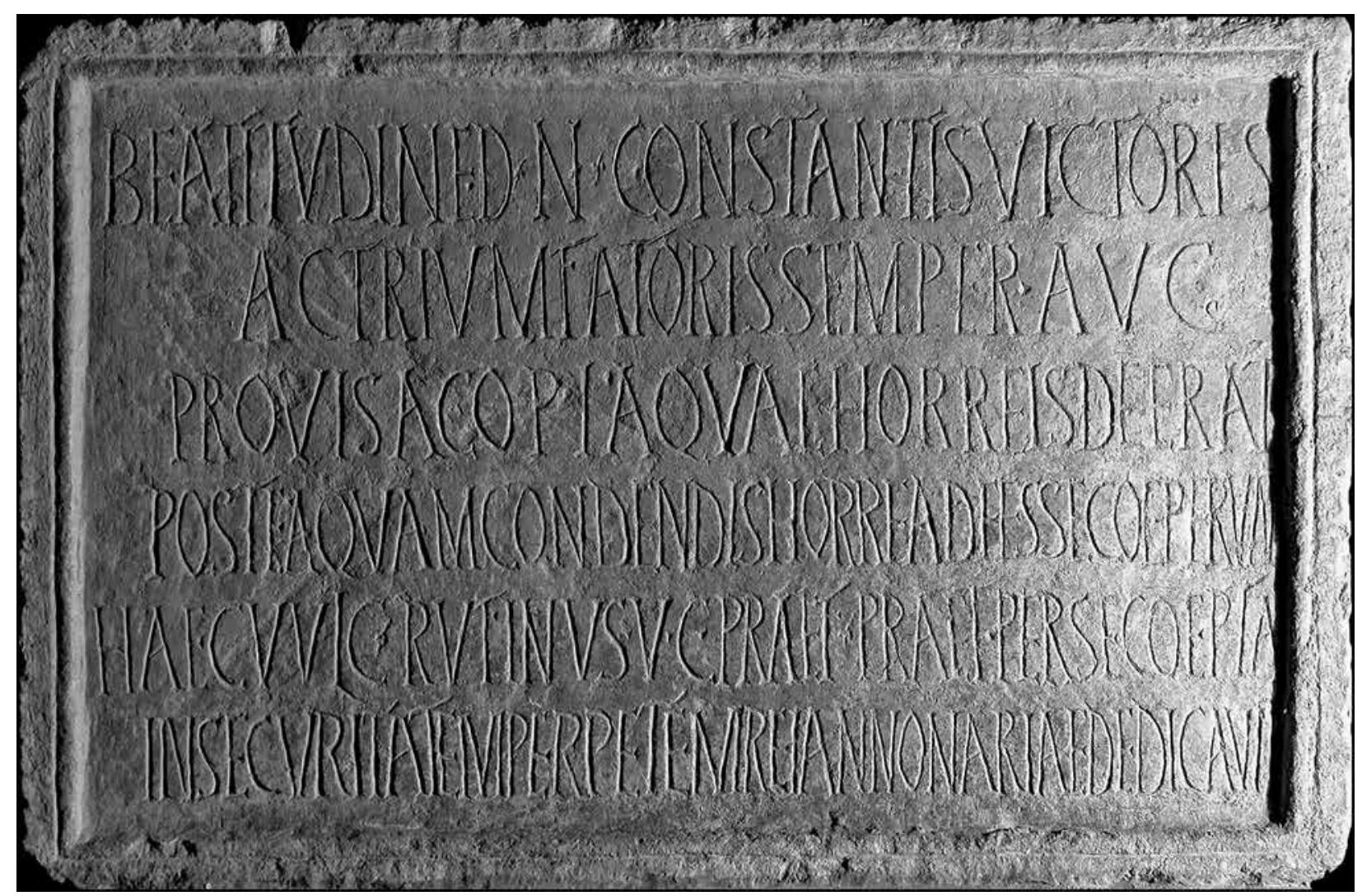

1. kép. Vulcacius Rufinus építési felirata (fotó: Kiss Péter)

Abb. 1. Bauinschrift von Vulcacius Rufinus (Foto: Péter Kiss)

irat értelmezése Savariára vonatkozóan vet fel kérdéseket történeti és topográfiai szempontból egyaránt. További kérdés, hogy a feliratot lehet-e régészeti jelenséghez kötni, azaz ismerünk-e olyan épületet, amely az említett horreummal azonosítható lenne.

\section{A horreum építését megörökító tábla}

Savaria és egyben a pannoniai tartományok gabonatárolására vonatkozóan kiemelten fontos az az építési felirat, amelyet C. Vulcacius Rufinus praefectus praetorio állított egy savariai horreum építése kapcsán (1. kép). ${ }^{3}$ A jellegzetesen késő antik betútípussal vésett és keretelt márványtábla folyamatosan a nemzetközi kutatás érdeklődésének középpontjában van, ${ }^{4}$ de a hazai irodalomban mindeddig nem kapott kellő figyelmet:

3 CIL III 4180=RIU I 48.=LAPSAV 63-65 Nr. 8. A feliratra vonatkozó korábbi irodalommal.

4 Lásd legutóbb Rizos 2013 (a szerző a Balkán késő római katonai gabonaellátásáról szóló átfogó tanulmányának mottójául választotta), de korábban többek között: RICKMAN 1971, 184; Migl 1994, 108ff.
Beatitudine $\bullet d($ omini) $\bullet n($ ostri $) \bullet$ Constantis victoris / ac triumfatoris semper $\bullet$ Aug(usti) / provisa copia quae horreis deerat / postea quam condendis horrea deesse coeperunt / haec Vulc(acius)・Rufinus •v(ir)・ c(larissimus)•praef(ectus)•praet(orio)•per se coepta / in securitatem perpetem rei annonariae dedicavit.

A felirat lelőhelye bizonytalan. A kőemlék 1798-ban látott napvilágot, és két különböző forrás két különböző lelóhelyet ad meg: vagy az egykori ún. Czédler-ház kertjében (a mai Kőszegi utca 27. sz.), azaz Savaria északi részén, vagy az egykori Gyöngyös utcában (ma a Fő tér keleti vége), azaz a város délkeleti részén találták. Ezt követóen Reich Pál patikus Fő téren álló házának falába (Fő tér 8. sz.) építették be, ahonnan a kőemlék 1872-ben került a Régészeti Egylethez. ${ }^{5}$ A rendelkezésünkre álló információk alapján a felirat előkerülési helye egyértelmúen nem dönthető el.

Annál jobban ismerjük a különböző forrásokból ${ }^{6}$ C. Vulcacius Rufinus alakját, akinek teljes cursus honoruma egy Róma városi feliraton maradt fenn. ${ }^{7}$ Ezenkívül törvények, rescripta szöve-

\footnotetext{
5 Ehhez részletesen lásd LAPSAV 63-65.

6 PLRE 1.782-3. és PORTMANN 2001, 1153-1154.

7 CIL VI 32051=ILS 1237: Singulari auctoritatis splendore pollen/ti admirabilisque eloquentiae beni/volenti(a)e felicitate glorioso cunc-/
} 
gezésében kerül említésre, sőt még Ammianus Marcellinusnál is többször feltúnik.

Constantius Gallus caesar nagybátyjaként ${ }^{8} \mathrm{C}$. Vulcacius Rufinus mindig is a politika fősodrában volt, korának egyik legtekintélyesebb politikusa lehetett. Korai politikai pályáját Numidiában kezdte, ahol egy pontosan nem keltezhetó albumfeliraton patronusként jelenik meg. ${ }^{9} 344$ májusa után Furius Placidus utódjaként praefectus praetorio Italiae, Illyrici et Africae lett. ${ }^{10}$ Ebbéli tisztségét erősíti meg egy Mediolanumban kiadott császári rendelet, ${ }^{11}$ amelyben annak végrehajtójaként bort gyújt be a cellarii számára. Ezt követóen 347-ben consul lesz, ${ }^{12}$ majd az ekkor létrehozott praefectura praetorio per Illyricum - valószínúleg elsó praefectusa. A források ezután inkább az illyricumi ténykedésére utalnak. ${ }^{13}$ Feltehetőleg 352-ig viselte a praefectus praetorio per Illyrici tisztséget. 354-ben már praefectus praetorio Galliarum, de mivel Aquitaniából a rajnai harcmezőre nem tudta biztosítani az ellátmány szállítását, ezért II. Constantius hamarosan eltávolította. ${ }^{14}$ Ezt követóen újra az itáliai térségbe érkezik, és 365-368 között praefectus praetorio Italiae et A fricae, ${ }^{15}$ amely tisztség betöltése során 368-ban meghal. ${ }^{16}$

A savariai felirat keltezését illetóen az az elfogadott nézet, hogy 347 és 352 közé tehető, tehát az illyricumi praefectus praetoriosága idejére. Mivel 347-es konzulsága előtt már az Illyricumot is magában foglaló praefecturában volt aktív, ezért a korábbi keltezést nem lehet egyértelmúen kizárni. Miután a savariai felirat a konzulságot nem említi, ezért J. Migl feltételezi, hogy még a konzulsága előtt, azaz 347 előtt már Illyricumban is aktív lehetett. Elképzelhető, hogy Rufinus a

tarumq(ue) dignitatum fastigia fabo/rabili moderatione iustitiae super/gresso Vulcacio Rufino v(iro) c(larissimo) cons(uli) / ordin(ario) praef(ecto) praetorio comiti / per Orientem Aegypti et Mesopotamiae / per easdem vice sacra iudicanti / comiti ordinis primi intra consistori/um Numidiae consulari pontifici maiori / ob innumerabiles sublimis benig(ni) tatis titulos / Ravennates monumentum perennis / memoriae in vestibulo domus statuali vene/ratione dicaverunt $\{u t\} .$.

8 Amm. Marc. 14.10.4.

9 CIL VIII 2403.

10 Furius Placidus 344. május 28-án még praefectus praetorio, lásd PLRE 1, 705. (Rufinus 25).

11 Codex Theodosianus XI 1,6.

12 Neve még egy 347-re keltezett paestumi tabulán is megjelenik Flavius Eusebius konzultársával együtt: L'Année Épigraphique (Paris) 1990, 0211=EDH HD016284

13 A Magnentius és Constantius közötti harcokban Constantius mellé áll, a Vetranio-féle illyricumi usurpatio elsimításában nagy szerepe van. 351 végén a mursai csata után nem sokkal Photinus perénél még ott van Sirmiumban. - MigL 1994, 116-117; Epiphanius, adversus Haereses 71.

14 Amm. Marc. 14.10.4.

15 PLRE I, 782-783. Amm. Marc. is többször említi: 22.12.24; 27.7.2; 27.11.1.

16 Amm. Marc. 27.11.1. tisztséget megosztva viselte Ulpius Limeniusszal (aki a praefectus praetorio Urbi tisztséget is betöltötte), és Eszak-Itália, valamint az illyricumi provinciák tartoztak a hatáskörébe, míg Limeniusé Róma város és az attól délre eső területek voltak, ami egybeesett volna Itália püspöki területfelosztásával. ${ }^{17}$ Migl szerint a konzulsággal együtt viselte még ezt a tisztséget, azaz itáliai praefectus praetoriosága után/mellett(?) még kinevezték Illyricumba. ${ }^{18}$

A fentiekből a feliratot illetően a következő derül ki: ha elfogadjuk azt a tényt, hogy a savariai felirat nem említi a konzulságot, és ez azt is jelenti, hogy ebben az idóben még nem volt konzul, akkor a feliratot valamikor 344 és 347 közé tehetjük. Véleményünk szerint, amennyiben Rufinus a felirat állításakor már a konzuli tisztséget is maga mögött tudhatta, ez a feliraton mindenképpen említésre került volna, ezért ezt a korábbi, 344347-es keltezést tartjuk valószínúnek. Más vélemények szerint Rufinus kiemelt horrea-építkezése Constans 349-es illyricumi látogatásával függ öszsze, ${ }^{19}$ ebben az esetben a magasabb consulatus rang hiánya a feliraton nem magyarázható.

Ami a feliratból egyértelmú, hogy biztosan hivatalos állami építkezésról tudósít, amely vagy a praeses officiumának, vagy a katonai ellátmánynak (annona militaris) a biztosítását szolgálta. ${ }^{20}$ Erre utal Vulcacius Rufinus személye és tisztsége is, hiszen a Nagy Constantinus alatti közigazgatási átszervezést követően a négy praefectura kialakítása után az azokat vezetó praefecti praetorio az adott praefectura civil adminisztrációjának a csúcsán álltak. Összekötő kapocsként múködtek a territoriális és a központi császári adminisztráció között. Elsősorban civil feladatokat teljesítettek, többek között az igazságszolgáltatásban, az adózásban, illetve a provinciák hivatalos rendjének, civil adminisztrációjának felügyelete is hatáskörükbe tartozott. ${ }^{21}$

\section{Savaria a késő antik időszakban}

Ahhoz, hogy Savariának a birodalmi gabonaellátásban betöltött szerepét megérthessük, a várost és a tartományt érintő közigazgatási és katonai átszervezés legfontosabb állomásait szükséges

17 MigL 1994, 115.

18 MigL 1994, 108-110.

19 Poulter 1992, 108. Általában a konzulátus utánra, 347-350 közé teszi a PLRE is, illetve Buócz Teréria - irodalmi hivatkozás nélkül - nagyjából ugyanerre az időszakra (346. március 8. és 349. december 28. közé) keltezte a követ: Buócz 2003, 58.

20 A kérdésről összefoglaló jelleggel legutóbb: MiтTHOF 2001; RICKMAN 1971, 264. skk.

21 GutsFeld 2001, 249-252, főleg 251-252. 


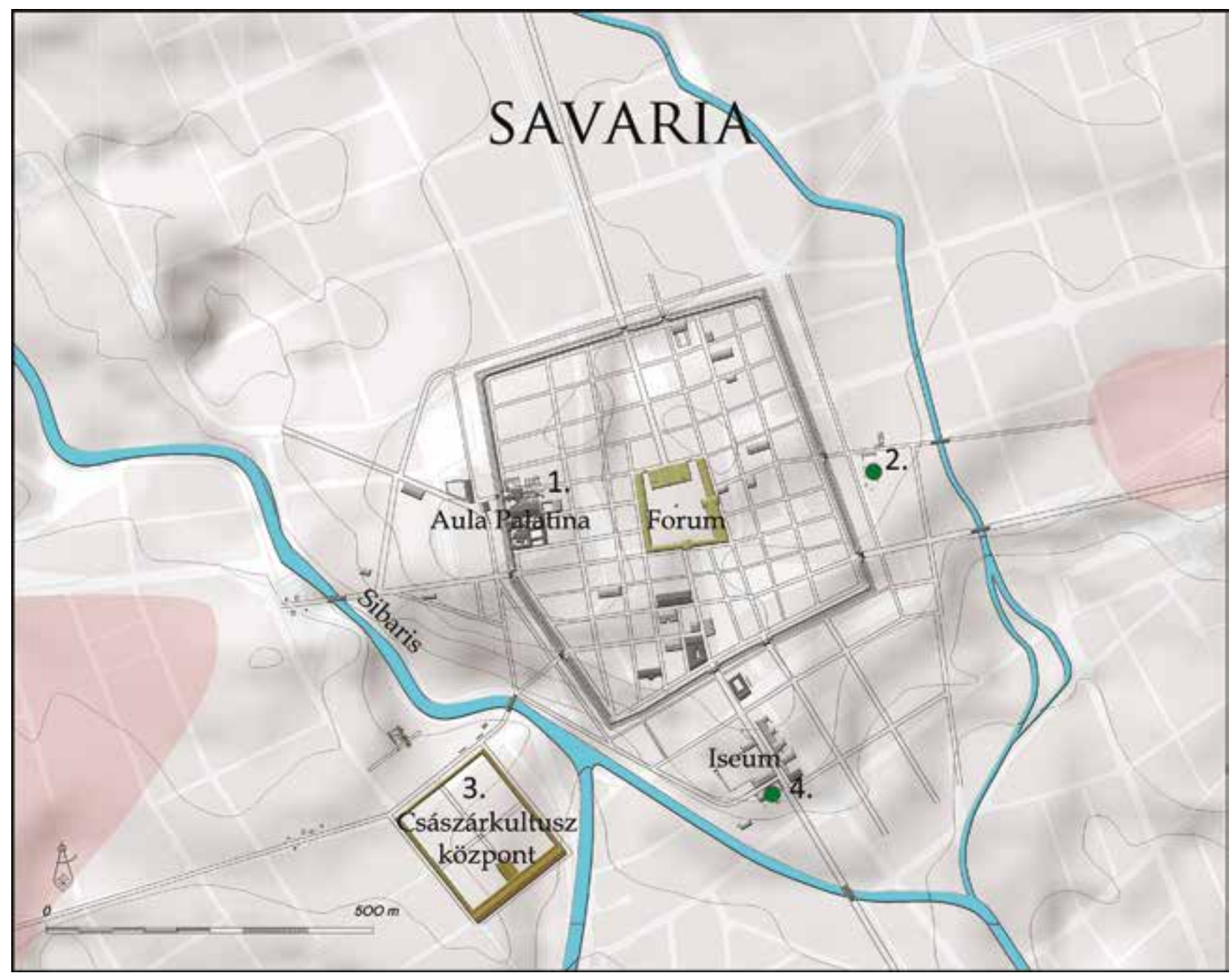

2. kép. Savaria a Kr. u. 3-4. században. 1: a tartományigazgatási központ a palota dísztermével; 2: az ún. keleti „horreum”; 3: a lancearii Savarienses feltételezett táborhelye az egykori császárkultuszközpont helyén; 4: a déli horreum (a korábbi kutatási eredmények alapján szerkesztette Derdák Ferenc és Isztin Gyula)

Abb. 2. Savaria im 3.-4. Jh. 1: Das Verwaltungszentrum der Provinz mit dem Prunksaal des Palastes; 2: Das sog. östliche „Horreum”; 3: Das vermutete Befestigungsareal der Lancearii Savarienses auf dem Gebiet des ehemaligen Kaiserkultes; 4: Das südliche Horreum (Von Ferenc Derdák und Gyula Isztin fertiggestellt, aufgrund der früheren Ausgrabungsergebnisse)

áttekintenünk. A Kr. u. 3. század válságait követő, az állami élet szinte minden részére kiterjedő diocletianusi reform több lépcsőben elhúzódva a 4. század első harmadában zárult le. ${ }^{22}$ Savaria jelentőségét ekkor már a korábban közel negyed évezreden át betöltött vallási szere ${ }^{23}$ helyett a Pannonia Superior kettéosztása révén létrejött új tartomány, a Pannonia Prima polgári igazgatásában betöltött központi szerep határozta meg. Az erről az időszakról alkotott képünk sajnos nem lehet teljes, hiszen a fennmaradt források gyakran egymásnak ellentmondó adatokat közölnek. ${ }^{24}$ Annyi azonban bizonyos, hogy 303-ban

22 KovÁcs 2011, 188-189; SZABÓ-BORHY 2015, 194.

23 Kiss-Tóth-ZÁGorHidi CZIGÁNY 1998, 27; TóTH 2001, 5-33.

24 Összefoglalóan KIss-TótH-ZÁgorhidi CZIGÁNY 1998, 56-67; То́тH 2016, 174; BALLA 1963, 75-80.
Savariában már a részben átalakult új igazgatás múködött, hiszen Quirinus, Sicia püspöke perében Amantius már mint praeses iudex járt el. ${ }^{25}$ Arra viszont nincs bizonyíték, hogy a közigazgatás teljes apparátusát ekkorra kiépítették volna. Egyes hivatalok csak jóval Constantinusnak a Licinius felett aratott győzelmét követően, 314324 között álltak fel. A korábban Poetovióban múködő tartományi pénzügyi igazgatás ${ }^{26}$ a város Noricumhoz csatolásával teljes egészében az új helytartói centrumba tevődött át, így az azt felügyelö praepositus thesaurorum is Savariába tette át

25 Passio Quirini 5, 6-7. Vö. Nagy 1939, 56, 20. lj.; NAGY [2017]. A 303-as keltezéshez: BRATOž 1990, 513-514.

26 Poetovio Kr. u. 311-ben a Noricumból leválasztott új tartomány, Noricum Mediterraneum része lett. Mócsy-FITz 1990, 69. 
székhelyét. ${ }^{27}$ A Pannonia Prima területén lévő császári erdők (silvae domenicae) igazgatása is feltehetőleg itt múködött, miután ezek felülvigyázóját említi egy Pornóapátiban előkerült felirat, ami időközben elveszett. ${ }^{28}$

Feltehetóen a helytartó és hivatalainak védelmére, különösen az idekerült thesaurarium védelmére állították fel a Lanciarii Savarienses csapategységet, ${ }^{29}$ amely egyike volt a 12 elitalakulatból álló legiones palatinae-nek. ${ }^{30}$ Máig kérdéses a csapategység létszáma, itt-tartózkodásának időrendje és tisztázatlan a városon belüli elhelyezésének kérdése is. Tóth Endre úgy gondolta, hogy táborukat a város nyugati oldalán, az egykori ebben az idóben már nyilván használaton kívüli - pogány kultuszközpont helyén építhették fel (2. kép). Egyelőre sem innen, sem a colonia más területéről nem ismertek markáns késő római militaria-leletek.

Savaria alapításkori helyválasztása, illetve a tartomány közlekedési rendszerében évszázadokig betöltött szerepe a 4 . század történéseiben is visszaköszön. ${ }^{31}$ A 4 . századi katonai és politikai események során Savaria (Sabaria, ahogy már ekkor nevezik) $)^{32}$ kitüntetett helyét jól mutatja, hogy az uralkodók nem csupán átutaztak, de rövidebb-hosszabb ideig időztek is e helytartói székhelyen. A császárok tartós jelenlétét jól igazolják innen keltezett rendeleteik, ${ }^{33}$ de rajtuk kívül a birodalmi szintú igazgatás szereplói is nyilván hivatali feladataik miatt - tevékenykedtek a város falai között.

Az uralkodóknak ${ }^{34}$ és a birodalom előkelőségeinek a rangjukhoz méltó elhelyezéséről az idők

27 Notitia Dignitatum Occ. XI. 25. Vö. MócsY-FITZ 1990, 69.

28 CIL III 4217=RIU I 128=LAPSAV 234 Nr. 198. Vö. NAGY [2017].

29 Notitia Dignitatum Occ. V. 152.

30 Notitia Dignitatum Occ. V. 9. KIss-TótH-ZÁGORHIDI CZIGÁNY 1998, 57; То́тн 2011, 280.

31 Itinerarium Antonini 231,8-241,5; 261,4-262,8; 263,3-9; 262,9$263,2$.

32 Kiss-Tóth-ZÁGorhidi CZigány 1998, 123-124, 270 (korábbi irodalommal).

33 Constantinus császár 322. július 26-án Savariából keltezte a lusitaniai rendeletét (Codex Theodosianus I. 1,1; Tо́тH 2011 280). Fia, Constans az uralkodása alatt ezt az ajándékozást erősítette meg 339. április 6-án szintén Savariában (Codex Theodosianus X. 10,6). 368-369-ben I. Valentinianus császárnak az aurum coronariumról és az adóemelésekről szóló rendeleteit Claudius Petronius Probus, a praefectus praetorio ebben a városban fogadta (KIss-TótH-ZÁGORHIDI CZIGÁNY 1998, 60).

34 Az előző jegyzetben szereplő császárlátogatásokon túl az alábbiak ismertek: Constantinus 314 júniusában Treviriből indult Cibalaeba, ahol 314 októberében legyőzte Liciniust. Ezen az úton át kellett vonulnia Savarián is. I. Valentinianus császár 375 telét a városban töltötte, innen indult végzetes útjára Brigetióba (Amm. Marc. XXX, 5.14). 379-ben pedig Gratianus császár is érintette Savariát, amikor a Rajna vidékéról Sirmiumba vonult (KIss-TótH-ZÁgorHidi CZIGÁNY 1998, 60). folyamán kibővített és kényelmi elemekkel kiegészített helytartói palota, valamint az uralkodói reprezentáció igényeihez igazított díszterem, az aula palatina gondoskodott. ${ }^{35} \mathrm{~A}$ birodalom- és tartományszervezés révén felduzzadt hivatali apparátus, valamint a népes kísérettel járó császárlátogatások az élelmiszer-ellátás terén is egyre nagyobb feladatot jelentettek, így az élelmezést egy kibővült infrastruktúra és a hozzá tartozó építmények biztosították.

\section{Savariai horreumok építészeti maradványai}

A külföldi kutatás előkelő helyen foglalkozik a felirattal, de horreumhoz köthetó építészeti maradványról nem tesz említést. Ennek nyilvánvaló oka, hogy a lehetséges épületek kutatásáról az ásatók rövid híradásait leszámítva nincsenek érdemi közlések sem a magyar, sem a külföldi régészeti irodalomban. ${ }^{36} \mathrm{~A}$ kérdések tehát adottak.

- Az említett feliraton kívül van-e régészeti bizonyítéka savariai (gabona)raktárak létezésének?

- Lehet-e azonosítani bármely eddig megtalált késő római épülettel a feliraton említett horreumot?

- Behatárolható-e egyáltalán, hogy hol kellene keresnünk? Vannak-e érveink, hogy a római város mely térségén kell ilyennel számolnunk? A magyar szakirodalomban eddig két lehetséges horreumként azonosítható épület került elö, az egyik a várostól délre kivezetô Borostyánkő út mentén, az egykori Iseum közvetlen szomszédságában, a másik a feltételezett keleti városkapu közelében, szintén a városon kívül. ${ }^{37}$ A következőkben ezt a két épületet mutatjuk be.

\section{Horreum az Iseumtól délre}

A vizsgált épület maradványai a colonia déli városfalán kívül a feltételezett déli városkaputól ${ }^{38}$

35 Korábban Tóth Endre a palota késői fázisának keltezésére a tetrarchia korát javasolta (То́тн 1973, 130-131; То́тн 1976, passim; KIss-TóT-ZÁGORHIDI CZIGÁNY 1998, 58). Késóbbi keltezést is lehetségesnek látott, mivel a palotakomplexumnak Valentinianus látogatása idején mindenképpen késznek kellett lennie (TóTH 2011, 278-281; IsZTIN-TÁRCZY-TÓTH 2013, 196).

36 Így pl. Rizos 2013, 659.

37 LAPSAV 65.

38 Lipp Vilmos híradását (LIPP 1872a; LIPP 1872b, 103) sokáig a déli városkapuhoz kötötte a kutatás, azonban mára kiderült, téves volt az utcanév azonosítása, és a maradványok valójában az északi városkaput jelölik. Ennek ellenére a 1990-es évek elején előkerült déli városfal és a Borostyánkő út nyomvonalából a feltárók helyesen következtettek a déli városkapu helyére. Vö. SOSZTARITS 1994, 234; MedGyes 1997; Medgyes 1998, 90. 


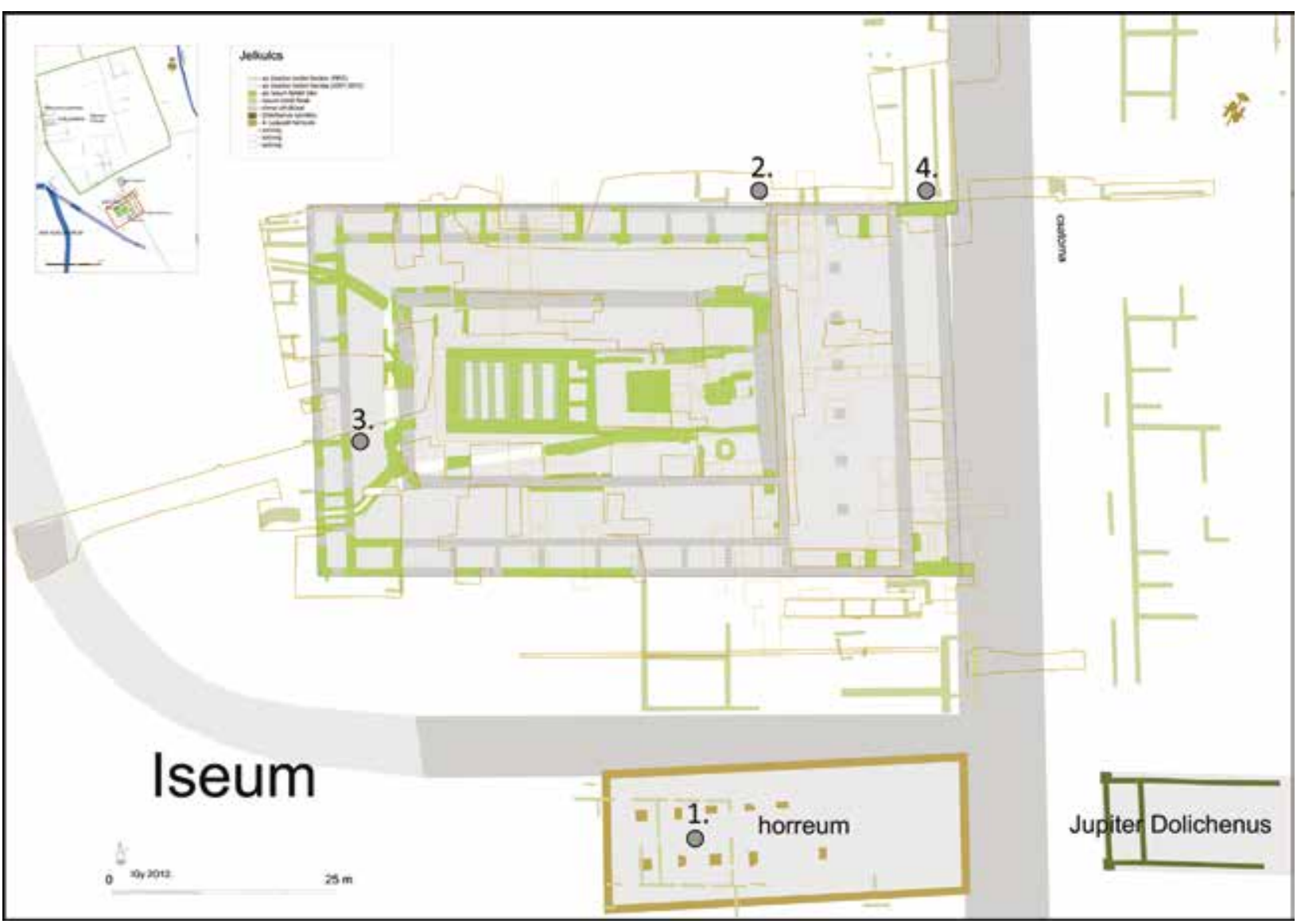

3. kép. A déli horreum és környéke. 1: az 1. sz. malomgarat lelőhelye; 2: a 2. sz. malomgarat-töredék lelőhelye. 3: a 3. sz. modiustöredék; 4: a Lipp V. által leírt gabonahalom feltételezett helye (grafika: Isztin Gyula és Kiss Tamás)

Abb. 3. Das südliche Horreum und seine Umgebung. 1: Der Fundort des Mühlsteines Nr. 1; 2: Der Fundort des Mühlsteines Nr. 2; 3: De Fundort des Modiusfragments Nr. 3; 4: Die vermutete Lokalisation des von V. Lipp beschriebenen Getreidehaufen. (Grafik: Gyula Isztin und Tamás Kiss)

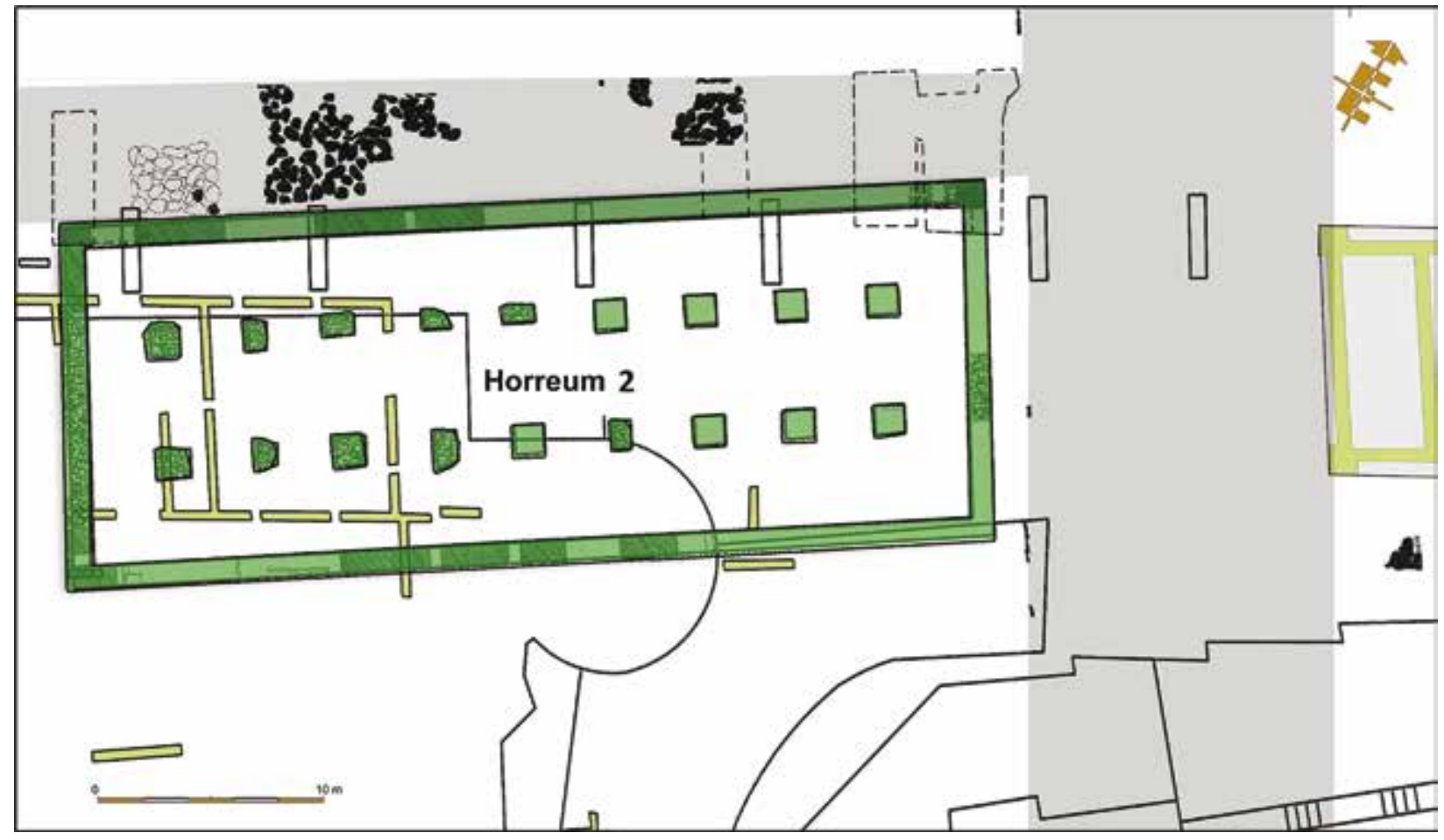

4. kép. A déli horreum alaprajza, szaggatott vonallal a 2013-2015. évi kutatások (Cserményi Vajk 1978-1979. évi és a 20132015. évi ásatási eredmények felhasználásával készítette: Isztin Gyula és Kiss Tamás)

Abb. 4. Grundriss des südlichen Horreums, die Grabung 2013-2015 mit gestrichelter Linie (Grafik von Gyula Isztin und Tamás Kiss, aufgrund der Ausgrabungsergebnisse 1978-1979 von Vajk Cserményi und 2013-2015) 
kb. 250 méter távolságra, az Iseum keleti homlokzata előtt futó észak-déli irányú Borostyánkő út, illetve az Iseum insulát délról határoló, keletnyugati irányú bazaltborítású bekötőút csatlakozásában helyezkednek el (3. kép).

A területről szóló első tudósítás az Iseum ${ }^{39}$ romkert tervezett bővítését, illetve a Szombathelyi Képtár építését megelőző feltárások idejére tehető. 1968-ban Szentléleky Tihamér tárta fel a Borostyánkő út és az Iseum déli zárófalán kívül futó kelet-nyugati irányú út csatlakozását, ennek kapcsán az úttól délre, korábbi épületek planírozására épített 4-5. századi kőépítményeket említett. ${ }^{40}$ Egy évtizeddel késóbb, 1978-1979-ben a Cserményi Vajk vezette nagy felületú ásatások ismét érintették az úttól délre eső maradványokat. Kutatásai során az említett bazaltborítású úttest déli oldalán több periódusú beépítést lokalizált, amelyek között egy nagyjából 16×40 méter méretú, két belső pillérsorral három traktusra osztott, alaprajzában horreumokra emlékeztető épületet tárt fel részlegesen (4. kép). ${ }^{41}$ Cserményi kronológiai megállapításai szerint a vizsgált területen a 2. századi rendszertelen beépítést követően a 3. századtól szabályos rendszerú insula képe bontakozott ki. A 3. század közepére tehetó egy markáns pusztulási réteg majd pedig a "IV. sz. utolsó évtizedeiben épült horreum jelenti az utolsó megfigyelhetô épitési periódust." 42 Sajnos érdemi közlés, illetve a meglehetősen hiányos ásatási dokumentáció alapján a megállapításait nem tudjuk igazolni. ${ }^{43} \mathrm{Az}$ Iseum tágabb környékének megismerése, illetve a templomtömböt délről határoló út funkciójának és létesítési idejének meghatározása céljából, valamint a 4. századi épület topográfiájának és kronológiájának pontosítására 2013 és 2015 között újabb, hitelesítő jellegú régészeti kutatások folytak a Szombathelyi Képtár pilléreken álló galériás épülettömbje alatt. ${ }^{44}$

39 Az Iseum régészeti kutatásairól: SOSZTARITS 2010; BALÁzsCSAPLÁROS-SOSZTARITS 2013; a jelenlegi kiállítóhely modern kori történetéről: SOSZTARITS-BALÁZs 2017.

40 SZENTLÉLEKY 1969.

41 SZENTLÉLEKY-CSERMÉNYI 1979. A horreum rekonstruált képe: BALÁZS-CSAPLÁROS-SOSZTARITS 2013, 47.

42 CSERMÉNYI 1980.

43 Dokumentációja: Savaria Múzeum Régészeti Adattár 619, 1248-97; Savaria Múzeum Rajztár 2536/78; 2483/79; 24842534; a Magyar Nemzeti Múzeum Régészeti Adattárában nincsen nyoma, és sajnos a hiányzó dokumentumok az ásató hagyatékából sem kerültek elő.

44 Ásatási jelentés, Savaria Múzeum Régészeti Adattár 3501-14. A 2013. évad eredményeit összefoglaló előadások. Balázs Péter: Már nem szentély, még nem horreum? - Régésztechnikus tanásatás eredményei az Iseum Savariense déli oldalán. Előadás, elhangzott: Fiatal Római Korosok VIII. konferenciája Budapest, 2014. 04. 25., ill. Balázs PéterSosztarits Ottó: Topográfiai kutatások az Iseum Savariense
Ezen kutatások alapján a kelet-nyugati irányú utat az Iseum insulát délról határoló útként határozhatjuk meg, ami a szentélyegyüttes délnyugati sarkánál csatlakozhatott a Borostyánkó út várost elkerülő nyugati szakaszához. ${ }^{45}$ Ezen út vizsgálata a "horreum” épületének keltezése szempontjából fontos. Az út létesítése a 2. század közepén, ${ }^{46}$ az Iseum kiépülésével egy időben, használaton kívül kerülése a 4. század első felében ${ }^{47}$ történhetett. Az útburkolatot fedő pusztulási rétegek leletanyaga kapcsolódik a mezőgazdasági munkálatokhoz (vassarló, vaseszközök) és az Iseum lebontott épületeihez (márványburkolat-töredékek, padlótéglák, épületelem ólomcsapolása), utóbbi egyben azt is jelzi, hogy az Iseum megszúnésével az út is funkcióját veszti, az épületbontások során eltemetik, illetve a déli városfal előterében nagyobb szabású épületbontási munkálatokkal is lehet számolni. ${ }^{48}$

A korábbi kutatás által horreumként meghatározott épületnek az északkeleti sarkát és az északi falának egy szakaszát vizsgáltuk (5. kép). Egy $2 \mathrm{~m}$ hosszúságú falmaradvány kivételével csak az 1980-as években visszatöltött falkiszedés betöltését és alapárkát tudtuk dokumentálni. Az épület pontos keltezéséhez a falkiszedésekből (modern visszatöltés) és az alapozás által vágott rétegsorból nem sikerült datáló jellegú leletanyagot kinyernünk. Annyi bizonyos, hogy ez a terü-

déli oldalán. Előadás, elhangzott: Magyar Régészeti és Múvészettörténeti Társulat ülése, 2014. 05. 13.

A Nyugat-Magyarországi Egyetem - Savaria Egyetemi Központ és a Savaria Megyei Hatókörú Városi Múzeum együttmúködésének keretében az egyetem Történelemtudományi Intézeti Tanszék Régésztechnikus Képzésének ásatási gyakorlata volt a feltárás, képzésvezető Csapláros Andrea. Ásatásvezető Sosztarits Ottó és Bíró Szilvia régészek, a munkában részt vettek az Iseum Savariense, a Savaria Múzeum és az ArchaeoJedi Kft. munkatársai.

45 Szentléleky T. az Isis-szentély nyugati oldalán északnyugatdélkeleti irányú bazaltburkolatú utat tárt fel (SZENTLÉLEKY 1960). Ez a várost nyugatról elkerülő úttal azonosítható. Lásd még: MladoniczKI-SOSZTARiTs 2009, 346, Abb. 1.

$46 \mathrm{Az}$ utat teljes szélességében és mélységében átvágtuk, a viszonylag sekély útalapozási kavicsrétegekben és alattuk a csaknem $1 \mathrm{~m}$ vastag, agyagos-sóderes feltöltésrétegekben előkerült nagy mennyiségú datáló leletanyag alapján vált lehetségessé a keltezés. A kerámiák meghatározásáért Gabler Dénesnek tartozunk köszönettel.

$47 \mathrm{Az}$ útfelületet lefedő réteg kerámiaanyagának többségét a szürke, kvarcszemcsés áru alkotja, az ún. "tokodi kerámia”, amely a noricum-raetiai térségben "horreumkerámiaként” ismert. Az idesorolható termékek jellegzetesen főzőedények. A leletanyagból hiányzik a besimított áru, az ezeknél korábban megjelenó polírozott áruból is csak $2 \mathrm{db}$ volt azonosítható. A kerámiák meghatározását és keltezését Horváth Friderika végezte, munkáját ezúton is köszönjük.

48 BALÁZS-CSAPLÁROS-SOSZTARITS 2013, 47; SOSZTARITS 2010, 150 151; SOSZTARITS 2016, 40. 


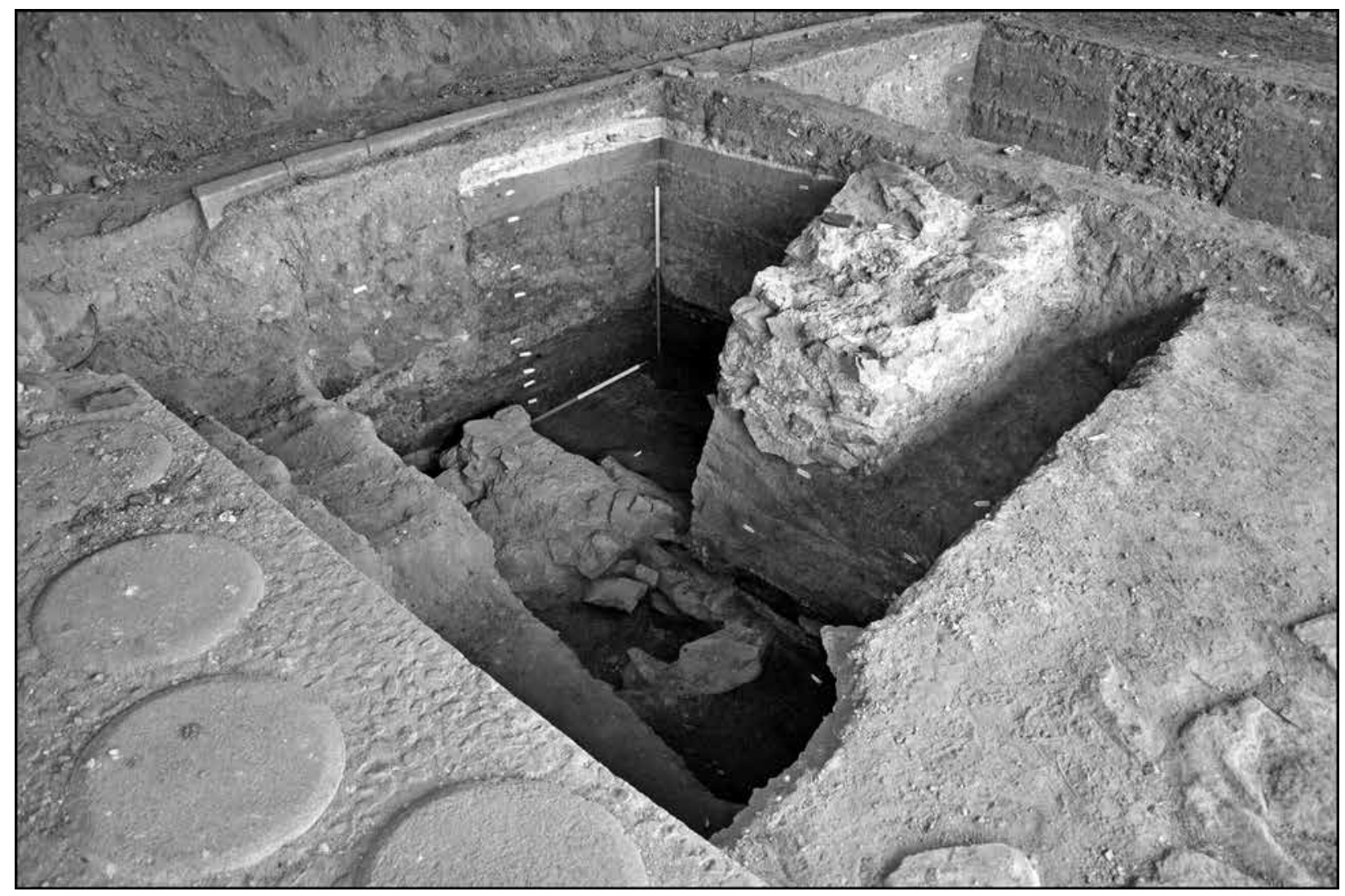

5. kép. A déli horreum feltárása 2015-ben ÉNY-ról. A metszetfalban a horreum falkiszedése, előtérben a megmaradt falszakasz (fotó: Iseum Savariense)

Abb. 5. Die Freilegung des südlichen Horreums 2015 von NW. Im hinteren Profil ist der Mauerausriss, im Vorne die erhaltene Mauerstrecke zu sehen (Foto: Iseum Savariense)

let legkésőbbi ${ }^{49}$ építménye, építésekor a Borostyánkó út még használatban van, a keleti homlokzata annak lett tolva. Az új létesítmény tájolása azonban némileg eltér a korábbi épületek (pl. Iseum), utak rendszerétől (az épület délnyugati sarkát belevágták az Iseumot délről határoló útba), jó részük ekkor már nem is áll. Erre utal, hogy falaiból az Iseum építési kövei, márványfaragványai és a kelet-nyugati út bazaltburkolatának darabjai is elókerültek. A kronológiát kiegészíti az a tény, hogy az Iseum „romjai” között szórványos temetkezések jelennek meg a 4 . század közepétől. ${ }^{50}$ Megjegyzendő, hogy sem az 1978-1979-es, sem a 2013-2015. évi feltárások során az épület területén temetkezés maradványait nem sikerült dokumentálni, a sírok inkább

49 „A IV. sz. utolsó évtizedeiben épült horreum jelenti az utolsó megfigyelhetô épitési periódust." CSERMÉNYI 1980. Számunkra nem ismert, milyen információkra alapozta Cserményi a fenti megállapítását, de amennyiben az helytálló, úgy a horreumot Savaria ma ismert legkésőbbi középítkezésének kell tartanunk!

50 A szentély pusztulásáról és utóéletéről: SOsZTARITS 2010, 149-151; BALÁZs-CSAPLÁros-SOSZTARITS 2013，44-55; BíróSOSZTARITS 2013, 269-278. a körzet nyugati felén, az Iseum szentélyudvarának kútjától nyugatra kerültek elő. ${ }^{51}$ Újabban felmerült a város déli előterét lezáró - eddig 11-13. századinak gondolt - U alakú sánc késő római keltezése is, ám ez egyelőre hipotézis. ${ }^{52}$ Összefoglalóan megállapíthatjuk, hogy az épületet a 4. század közepe után építették, de ezt a feltárások leletanyaga alapján pontosabban nem lehet meghatározni.

Magáról az épületról a korábbi dokumentációk és az újabb hitelesító feltárások eredményei alapján az alábbi kép rajzolódik ki. Az épület 41 méter hosszú, 16 méter széles, belső terét két pillérsor három részre osztja. A soronként 9-9 db lekerekített sarkú négyszögletes kőpillér méretei átlagosan 130-140 cm×130-140 cm. A föfalak szélessége $\mathrm{kb} .90 \mathrm{~cm}$, a pillérsorok 3,6 méter távolságra húzódnak a belső falsíkkal párhuzamosan, a két pillérsor közötti belső távolság 4 méter, a

51 BALÁZs-CSAPLÁros-SOSZTARITS 2013, 45.

52 A sánc árka minden római kori réteget vágott, teljes feltöltődése csak a 19. században fejeződött be. Feltárásához lásd MedGYEs 1991; a jelenség értelmezéséhez és későbbi keltezéséhez vö. DERDÁK-KISS 1994. 


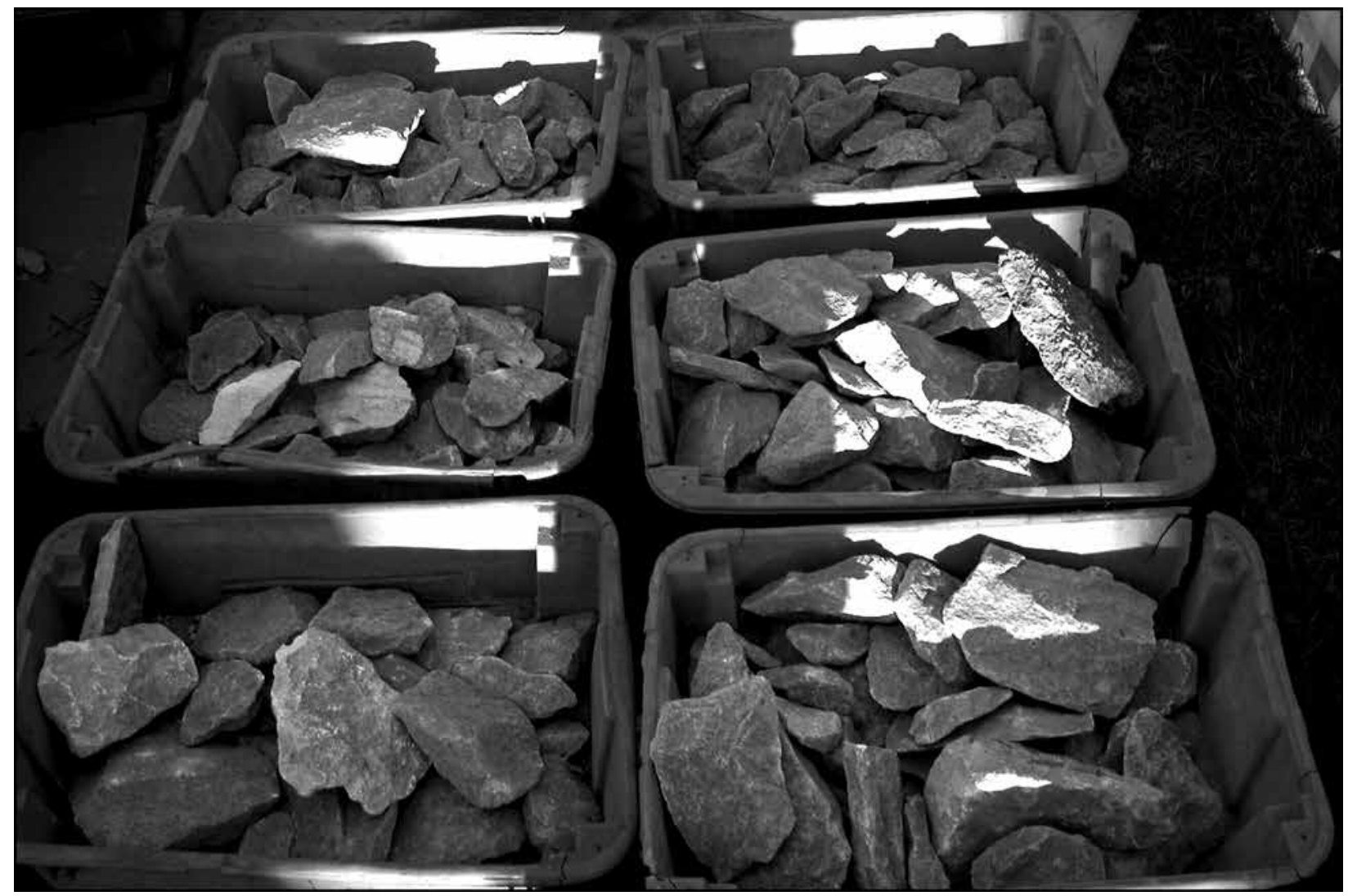

6. kép. A déli horreum területén 1978-1979 között talált, eredetileg az Iseumból származó márványtöredékek (fotó: Farkas Csilla)

Abb. 6. Auf dem Gebiet des südlichen Horreums 1978-1979 gefundene, original aus dem Iseum kommende Marmorfragmente (Foto: Csilla Farkas)

pillérek egymástól 2,6 méterre helyezkednek el a sorokban. Külső támpilléreknek nincs nyoma. Az alapfalak és pillérek általában a Borostyánkő út szintjéig (211,45 Bmf) vannak visszabontva, néhány pillér maradványai azonban 30-40 cm-rel magasabban jelentkeztek. A falak-falkiszedések a Borostyánkő út járófelületétől nagyjából 1 méterrel mélyebbre voltak alapozva. A falkiszedések az újkori feltöltés alatt közvetlenül jelentkeztek (5. kép).

A falak anyaga vegyes falazat, fehér, erősen meszes habarcsba rakva. A szokásos kloritpala és tégla mellett útburkoló bazaltot, az elbontott korábbi épületek márvány- és mészkő faragványainak töredékeit is felhasználták (6. kép). ${ }^{53} \mathrm{~A}$ konstrukció kevéssé igényes kivitelezése talán az építők sietségének tudható be, ennek ellenére rendkívül masszívra sikerült. Az épület belső

53 Az 1978-1979-es ásatásokon 12 láda különböző méretú márványtöredék került elő, közülük többet is azonosítani lehetett az Isis-szentély faragványaival. Legmarkánsabb ezek közül az előcsarnok hatalmas gránitoszlopainak márványlábazatába illeszthető plinthosztöredék (ISEUM KAT. 6.21), illetve párkánytöredék (ISEUM KAT. 6.19). sarkában alapozás nélküli, gyenge megtartású terrazzo padló került elő, ami stratigráfiailag nem lehetett a gabonatároló padlója. Az építmény padlószintje így a megtalált romokénál és a Borostyánkő út burkolatánál magasabban lehetett. Mindezek a granáriumokra jellemző emelt padozat (suspensurae) létére utalnak, de sem ez, sem az ehhez tartozó gerendavázas padozat ${ }^{54}$ léte nem bizonyítható.

\section{Gabonafeldolgozáshoz kapcsolható kőemlékek}

$\mathrm{Az}$ Iseum-körzet feltárásai során három olyan kőemlék is előkerült, amelyek gabonafeldolgo-

54 Hasonlót lehet elképzelni, mint Sopianae 4. század közepén épült horreumában: „Az épület belső terében, négyzetes rendszerben pillérek helyezkedtek el. Középpontjaik távolsága $\sim 3,70 \mathrm{~m}$, alapozásuk átlagosan $\sim 1 \times 1$ méter alapterületü. A pillérek alapozását a bazilika járószintjébe ásták bele, így nagymértékben tönkretették azt. A pillérek lábazati részét faragott, téglatest alakú kőtömbök képezik négyzethálós rendszerben. Ezek nem a tetöszerkezet tartópillérei, hanem a pillértávolságból adódóan az épület belső járószintjét alkotó fapadozatot tarthatták. Struktúrája alapján az épület raktár (horreum) lehetett." То́тн 2010, 107. 


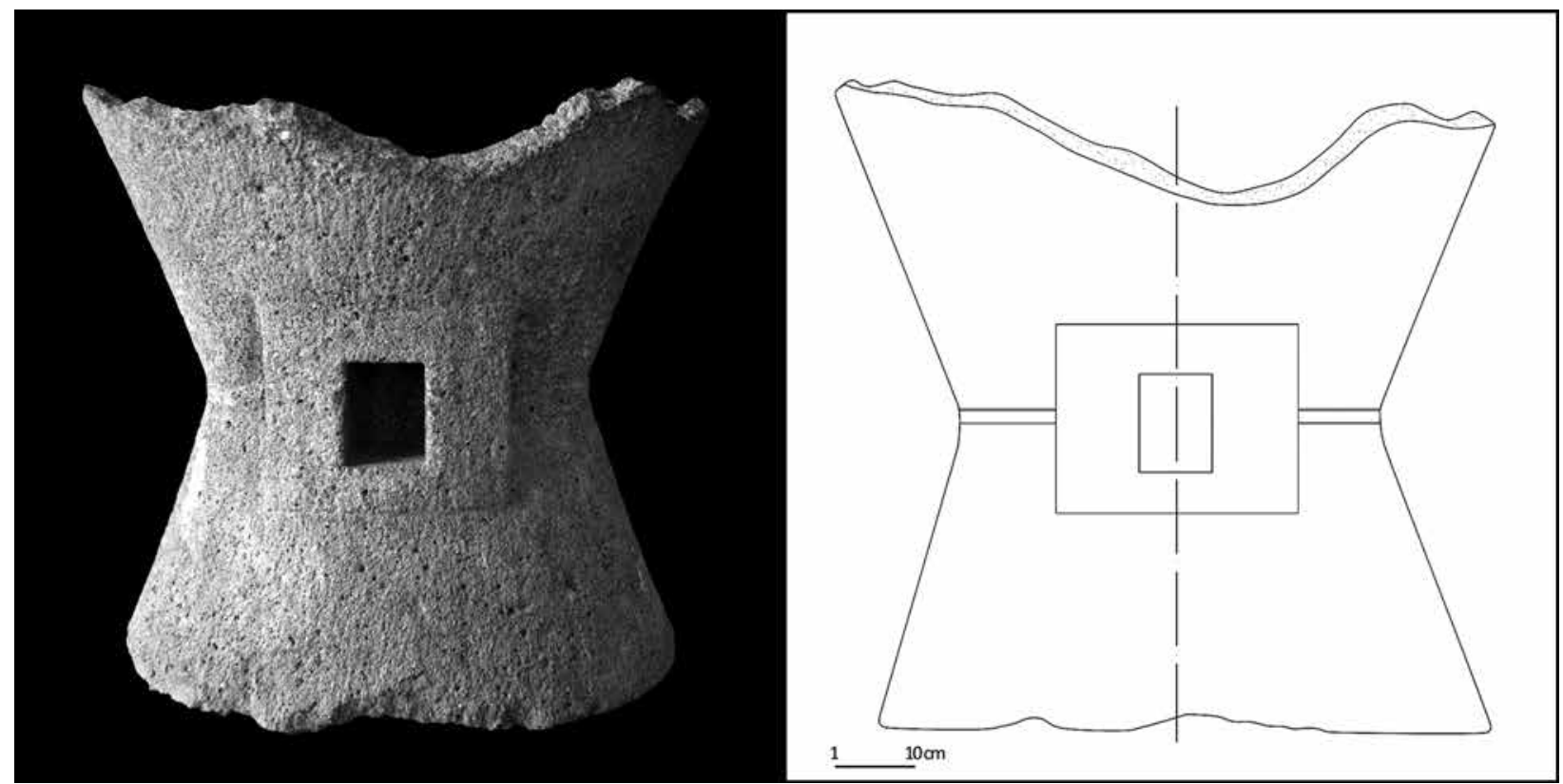

7. kép. Az 1. sz. malomgarat az 1978-1979. évi feltárásból (fotó: Hódi Attila; rajz: Bezeczky Tamás és Kiss Tamás)

Abb. 7. Der Mühlstein Nr. 1. aus der Grabung 1978-1979 (Foto: Attila Hódi; Zeichnung: Tamás Bezeczky, Tamás Kiss)

záshoz kapcsolhatók, és így bemutatásuk szükségszerú.

1. Malomgarat (7. kép). A szinte teljesen ép darab egy pompeji típusú malom felsó részeként (catillus) azonosítható. Az őrlókő alsó és felső pereme is töredezett állapotban került elő. A belső felületén javításra utalhat egy korrodált vaskapocs maradványa. A felső átméróje $80 \mathrm{~cm}$, az alsó részének átméróje $73 \mathrm{~cm}$, magassága $75 \mathrm{~cm}$, a tölcsér belső átmérője $20 \mathrm{~cm}$, a gerendafészek $9 \times 11,5 \mathrm{~cm}$. Anyaga szürke vulkáni tufa..$^{55}$ Formai jegyei alapján D. Peacock tipológiájában a pompeji 3c típusként határozható meg. ${ }^{56}$

Malomtöredékünk Cserményi Vajk - fentebb említett - 1979-es ásatásán került elő az Isis-szentélytől délre. Az ásató leírása alapján az őrlőkő a Borostyánkő úttól nyugatra egy 3. századi pusztulási rétegben feküdt csaknem teljesen ép állapotban. ${ }^{57} \mathrm{Az}$ ásatási dokumentációban fellelhetó rajzok alapján a malomkő lelőhelye az 1510-1511-es számú mező északi felére, a horreum két középső pillérsora közötti területre lokalizálható. ${ }^{58}$

2. Malomgarat töredéke (8. kép)..$^{59} \mathrm{Az}$ őrlőkő széttört, feldarabolt állapotban került a feltöltési rétegbe. A malom- garatból csak a gerendafészek és a catillus középső része maradt meg, alsó és felső része hiányos, törött. Szélesség: $41 \mathrm{~cm}$, magasság: $31 \mathrm{~cm}$, falvastagság: $4,5-8,5 \mathrm{~cm}$, a gerendafészek szélessége: $8,5 \mathrm{~cm}$, mélysége: $15 \mathrm{~cm}$. Mérete alapján azonban biztos, hogy az elóző darabnál kisebb példány töredéke. Anyaga szürke vulkáni tufa. Tipológiailag szintén a homokóra alakú malomkövek közé sorolható. Formai jegyei alapján a pompeji 2d típushoz áll a legközelebb. ${ }^{60}$

Az előbbi garattól északra, nagyjából 70 méternyi távolságban az Iseum északi zárófalához hozzáépített épület 6,6 méter széles helyiségében, a fal zoklijának szintje alatti egyik sóderes feltöltésben találták 2008-ban.

Keltezéséhez az alatta és felette levő rétegek leleteit kell segítségül hívnunk, ezek alapján földbe kerülését az Antoninus-korra - a 2. század közepére keltezhetjük. ${ }^{61}$

Mindkét kő alapanyaga vulkanikus eredetú tufa, ami az umbriai Orvieto környékén lévő bányák valamelyikéból származik. ${ }^{62}$ A bányák lokalizálását és az őrlőkövek készítésének és szállí-

55 Ltsz. nélkül ma az Iseum Savariense Régészeti Múhely és Tárház állandó kiállításán látható. Hódi 2015.

56 PEACOCK 1989, 207; BuFFONE et al. 1999, 120, Fig 7.

57 CSERMÉNYI 1980.

58 A Savaria Múzeum Régészeti Adattár 619 1510-1511 sz. mezők metszetrajzain (Szombathely Iseum-körzet, 1978. VIII. 4.) látható jelenség magyarázó felirat híján egyértelmúen nem azonosítható a malomkővel.

59 Ltsz. R. 2009.2.6966. Előkerülési helye: 51/A szelvény, KE 6022. POMPEjI KAT. 131. (Hódi A.)

60 PEACOCK 1989, 207.

61 Magából a rétegből Domitianus-Hadrianus-kori terra sigillata került elő 2. századi leletanyaggal; a közvetlenül felette levő rétegből (KE 2623) pedig az Antoninus-korra - a 2. század második felére keltezhető kerámiák. Az alatta levőt (KE 3263) a további leletek mellett a pannoniai szürke áru megléte inkább az 1. sz. legvégére - a 2. sz. elejére keltezi.

62 D. Peacock szíves szóbeli közlése, aki 2012 nyarán személyesen vizsgálta meg a köveket. 
tásának rekonstrukcióját D. Peacock vizsgálta, ezek szerint Itáliának ezen a részén - a kiváló alapanyag miatt - a bányák már a Kr. e. 1. századtól kezdve az őrlőkövek alapanyagának bányászatára és készítésére specializálták magukat. Az őrlőkövek kialakítása és megmunkálása még helyben történt meg, a bányák közeléből szinte teljesen kifaragott és félkész termékek kerültek elő. ${ }^{63} \mathrm{Az}$ itt készített őrlőkövek jó minőségük révén nagy értéket képviseltek, erre utal, hogy folyamatosan javították őket, ${ }^{64}$ mint az az ép, 1. sz. darabunkon is látszik.

Mindkét malomgarat az ún. pompeji típusú malmok alkatrészeként szolgált. A homokóra alakú malmok két részből állnak: az alsó, fix alkatrészük a meta, a felső, forgatható részük a catillus. A meta egy kúpban végződő henger alakú faragvány, melynek felső részébe egy függőleges fémtengelyt illesztettek. Ez az alkatrész távtartóként meghatározta a meta és a catillus közötti távolságot, és ezzel a gabonaőrlemény szemcsenagyságát is szabályozta. ${ }^{65}$ Rendkívül fontos volt a malmok pontos beállítása, mert túl nagy távolság esetén a két őrlőkő között darabos maradt az oorlemény, míg a túl szúkre állított kövek esetében „elégett” a készítmény.

A forgatható homokóra alakú catillus oldalába egy-egy szögletes gerendafészket mélyítettek. A gerendafészkek oldalsó kerek furataiba illesztett csapok a gerendák kifordulás elleni rögzítését biztosították. A vízszintes gerendák az állati erővel hajtott malmok forgatására szolgáltak: ezek mögé kötötték az öszvéreket vagy szamarakat.

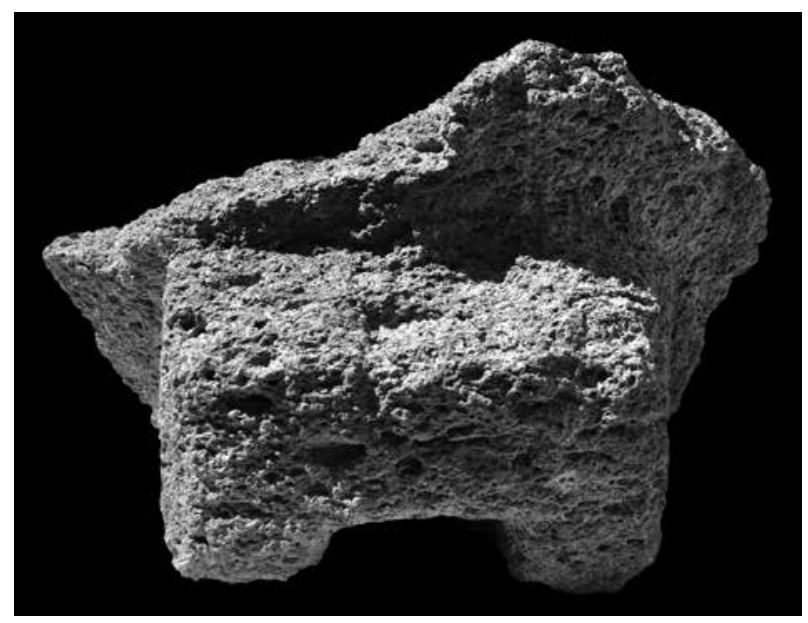

8. kép. A 2. sz. malomgarat töredéke a 2008. évi ásatásból (fotó: Hódi Attila)

Abb. 8. Das Mühlsteinfragment Nr. 2. aus der Grabung 2008 (Foto: Attila Hódi)

\footnotetext{
63 PEACOCK 2013, 87, Fig. 5.9. a,b,c.

64 PEACOCK 2013, 81, Fig. 5.3.

65 BAATz 1994, Fig. 20, 12 és Fig. 14.
}

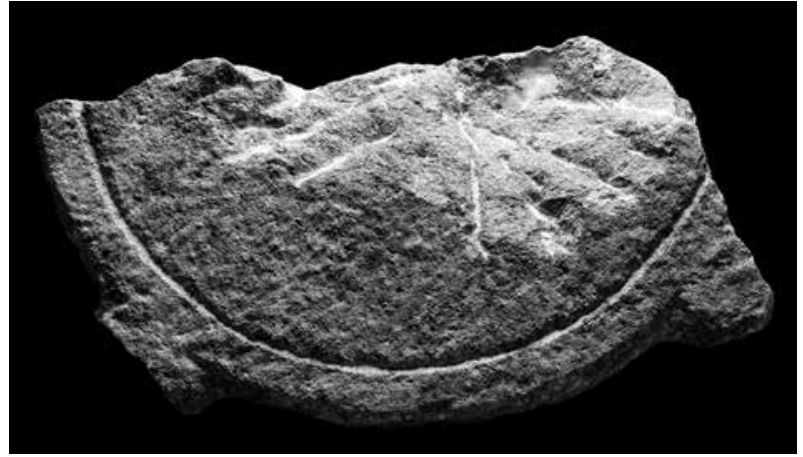

9. kép. A 3. sz. félkész modius az Iseumból (fotó: Vizi Péter)

Abb. 9. Der halbfertige Modius Nr. 3. aus dem Iseum (Foto: Péter Vizi)

Szintén a malmot hajtó állatok befogására szolgált a catillus tetején elhelyezett, fából ácsolt szerkezet is. ${ }^{66}$ Legismertebb példányai a pompeji Modestus pékségében találhatók. ${ }^{67} \mathrm{~A}$ malomtípus használata Ostiában a Kr. u. 3. század első feléig kimutatható. Nálunk is hasonló a tárgy földbe kerülésének keltezése.

A két malomgarat-töredékünk típusa alapján az ostiai párhuzamok segítségével több információ is kikövetkeztethető. Az ostiai pékségeket vizsgáló holland kutatók a malmok múködését emeletes épületekben képzelik el. A malomgaratok felső részébe fából készült csöveken át adagolták a gabonát az emeleti helyiségekből. ${ }^{68}$

A pompeji típusú malmok előfordulása Pannoniában viszonylag ritka, eddig alig néhány példányt ismerünk a provinciából. ${ }^{69}$

3. Félkész mérôedény (9. kép). Magasság: $32 \mathrm{~cm}$, vastagság: $30 \mathrm{~cm}$, átmérő: $69 \mathrm{~cm}$.

Az Iseum pódiumtemploma mögött nyitott kutatóárokban 2002-ben egy olyan mészkó párkánytöredéket ${ }^{70}$ találtunk, amelyet a késóbbiekben mérőedénnyé kívántak átfaragni. ${ }^{71} \mathrm{~A}$ kő előkarcolása és megkezdett faragása alapján egy kerek, négyfülú, sekély gabonamérő edény (modius) készült volna belőle, de a munka során a kő megsérült vagy eltörött, és befejezetlenül dobták el.

Pompejiben a gabonafélék őrlése és további feldolgozása egymás közvetlen közelében történt. ${ }^{72}$

66 PEACOCK 2013, 84, Fig. 5.7.

67 PEACOCK 2013, 78, Fig. 5.1.

68 BAKKER 1999, 1-15.

69 Carnuntum (PEACOCK 2013, 89, Fig. 5.10), Andautonia (Nemeth-Ehrlich-Kusan Spalj 2003, 117, Fig. 19).

70 A kőemlék anyaga - a legvalószínúbb, hogy főként a Lajta-hegységből, a St. Margaretheni bányákból származik - megegyezik az Iseum nem márványból készült homlokzati díszeivel.

71 7/A szelvény, szórvány. Ltsz. R.2011.4.140. IsEUM KAT. 6.10.

72 PEACOCK 2013, 77. 


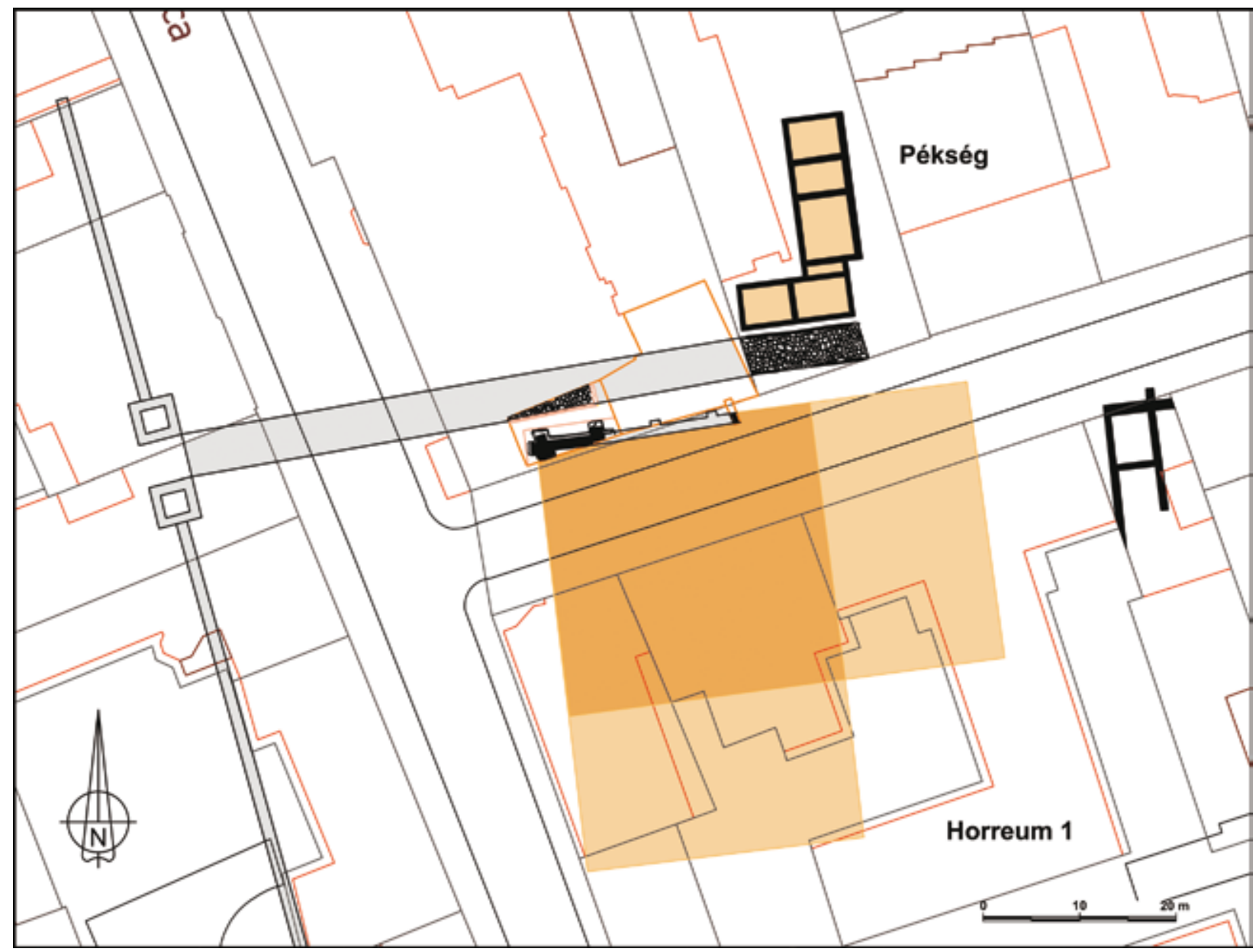

10. kép. A keleti „horreum” maradványai és környéke (Derdák Ferenc alaptérképének felhasználásával készítette Szilasi Attila Botond)

Abb. 10. Die freigelegten Mauerreste des östlichen „Horreums” und ihre Umgebung (Von Attila Botond Szilasi fertiggestellt, aufgrund der Grundkarte von Ferenc Derdák)

A városból jelenleg ismert 21 pékség 75 malommal, melyek nagyrészt a fontosabb belvárosi utcák közelében voltak. Ezekben a pékségekben a beszállított gabonát nem tárolták, hanem azonnal feldolgozták. Ezek szerint a pompeji pékségekben az őrléstől a kenyér árusításáig szinte minden egy helyen zajlott. A Róma kikötőjeként ismert Ostiában viszont óriási méretú gabonatárolókat építettek, melyek közelében több, ipari méretú pékség múködött állati erővel hajtott őrlőkövekkel, "dagasztógépekkel” és sütőkemencékkel. ${ }^{73}$

Az Isis-szentély közvetlen közeléből előkerült két pompeji típusú malomgarat-töredék, illetve a gabonaméró edénynek majdnem átalakított párkánytöredék mindenképpen a gabona helybeli ipari méretú feldolgozására utalnak. Noha a három kőtöredék kronológiailag különbözik egymástól, mindenképpen elgondolkodtató

73 BAKKER 1999, 114. Fig. 29. lelőhelyük közelsége, bár inkább topográfiai egybeesésről beszélhetünk, mint bizonyíthatóan folyamatos gabonafeldolgozásról. Mindezt ugyanakkor alátámasztaná, hogy az Iseumszentélykörzet kialakítása előtt a területen lokalizálható múhelyek között létezett malom is. A térség gabonával való szinte folyamatos kapcsolatát árnyalja a tény, hogy a területen kialakított Isis-szentélykörzet kultuszának egyik központi eleme a gabona. Az, hogy az Iseumszentélykörzethez északról csatlakozó épület, amelyben a malomkőtöredék (2. sz.) előkerült, ténylegesen gabonafeldolgozáshoz köthetô, nem jelenthető ki egyértelmúen.

A területen a gabonafeldolgozáshoz kapcsolódó jelenségek szinte folyamatos megléte azonban feltúnő, főleg ha hozzátesszük azt a tényt, hogy a fentebb bemutatott horreum épülete is ugyanezen körzet területén található. A raktárépület és a gabonafeldolgozás helyszíne között azonban 
kronológiailag semmilyen egyértelmú kapcsolat nem mutatható ki. Itt kell felvetnünk annak lehetőségét, hogy az Iseum előcsarnoka, illetve esetleg más, teljesen vissza nem bontott épületrészek a szentélykörzet vallásos funkciójának megszúnését követően a Rufinus-felirat által említett raktározási gondok enyhítése céljából időszakosan raktározási funkciót is elláthattak. Idetartozik esetleg a Lipp Vilmos által 1869-ben a mai szentélykörzet EK-i sarkánál végzett megfigyelés eredménye, amely szerint nagy mennyiségú gabona került elő az előcsarnok vagy inkább az ahhoz keletról csatlakozó porticus téglapadozatáról egy gyékénydarabbal együtt. ${ }^{74}$ Tóth István később a jelenséget egy áldozóhelyként azonosította, elsősorban az előkerült nagyszámú állatcsont (főleg birkakoponya) miatt. ${ }^{75}$ A 2007-2010 között a területen folyó régészeti feltárások azonban Tóth István felvetését nem támasztották alá, sőt Lipp Vilmos leírását is módosították: a nagy mennyiségú állatcsont egyértelmúen az Iseumot megelőző múhelyperiódushoz tartozhatott, viszont a feltárások során ekkor már egyértelmúen az Iseum keleti porticusához tartozó téglás járószintet csak ettől délebbre sikerült dokumentálni. ${ }^{76}$ A kérdés egyelőre nincs eldöntve, teljes körú vizsgálata meghaladja ennek a dolgozatnak a kereteit.

\section{Horreum a keleti külvárosban}

Savaria városfalától keletre, a városból kivezető út mentén állt egykor az az épület, amelyet a helyi kutatás kezdetektől fogva horreumként értelmez (10. kép). 1968-ban Buócz Terézia a MÁV Szombathelyi Igazgatóságának (ma a Kisfaludy utca és a Király utca sarok) épületbővítése/pinceépítése közben egy 6 méter széles római útszakaszt tárt fel, amely mellett „többhajós, monumentális keresztboltozatos épület alapfalai húzódtak". ${ }^{77}$

74 Lipp 1870, 43-44. „A csontok alatt a szögletben még meglehetős épségben megmaradt durva mozaik padozaton körülbelől egy mérőre menő félig elszenesedett búza feküdt mely alatt még egy szalma gyékénynek, szintén egészen elszenesedett, mintegy féllábnyi nagyságú darabját lelték. A búzába azonfelül egy kis római sírmécs, és több Constantin-féle apró rézérem volt temetve."

75 TóTH 1975; ezzel ellentétes véleményt fogalmaz meg THOMAS 1979, de egy önálló Magna Mater kultuszhely létét az itteni ásatási eredmények is kizárják: BALOGH-SOSZTARITS-SzILASI 2002, 183-184.

76 2008. évi 44. szelvény, keleti rábontás, illetve 51/A szelvény érintette a területet. Ásatásvezető: Sosztarits Ottó

77 Buócz 1969. Sajnos a múzeumi adattárban őrzött dokumentációban sem a többhajós elrendezésre, sem a boltozatos lefedésre nem találtunk érdemi adatot.

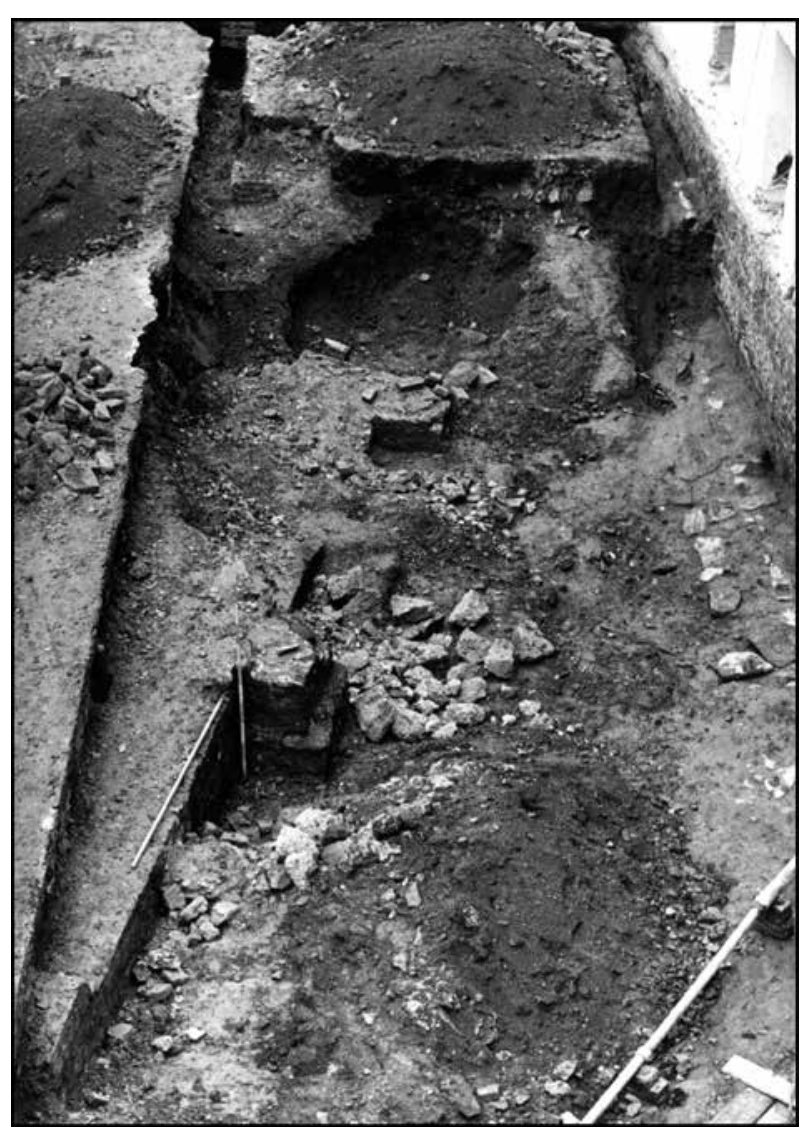

11. kép. A keleti „horreum” északi oldalán futó út maradványai az 1968-as ásatáson (fotó: Savaria Múzeum Adattár)

Abb. 11. Reste der nördlich vom östlichen "horreum” laufenden Straße aus der Grabung 1968 (Foto: Archiv von Savaria Museum)

A feltárt maradványokat konzerválták, így ma részben látogathatók.

A dokumentáció alapján az épület falát terméskőből és téglából vegyesen rakták, ${ }^{78}$ szélessége $110 \mathrm{~cm}$ volt. Az épület ÉNY-i sarkát, az azt két oldalról megtámasztó pillért, illetve az északi fal további, kelet felé futó vonalát sikerült mintegy 12,5 méter hosszan feltárni, amelyen további két pillér is mutatkozott (11. kép). Ezek középvonala egymástól 6,25 méterre volt. A fal alapozása a feltárási összesítő rajz szerint kifelé $32-35 \mathrm{~cm}$ rel szélesebb, mint a felmenő szerkezet. A belső oldalt nem ismerjük, mert az épület belseje lényegében feltáratlan maradt. A saroktól számított első külső támpilléren kettős alapozási kiugrás látszódik, így a dokumentált falalapozás alja valójában $48 \mathrm{~cm}$-rel szélesebb a felmenó falnál. Az építkezés során ettől keletre egy gázbekötés árkában, a mai járda alatt sikerült az északi fal

78 Buócz T. ásatási dokumentációja, Savaria Múzeum Régészeti Adattár 365. 
egy további szakaszát dokumentálni, így 21 méter hosszan kiszerkeszthetővé vált az épület északi zárófala.

Talán ehhez az épülethez tartozhatnak azok a falszakaszok is, amelyeket a mai épület előtti útszakasz alatt dokumentáltak még néhány évvel

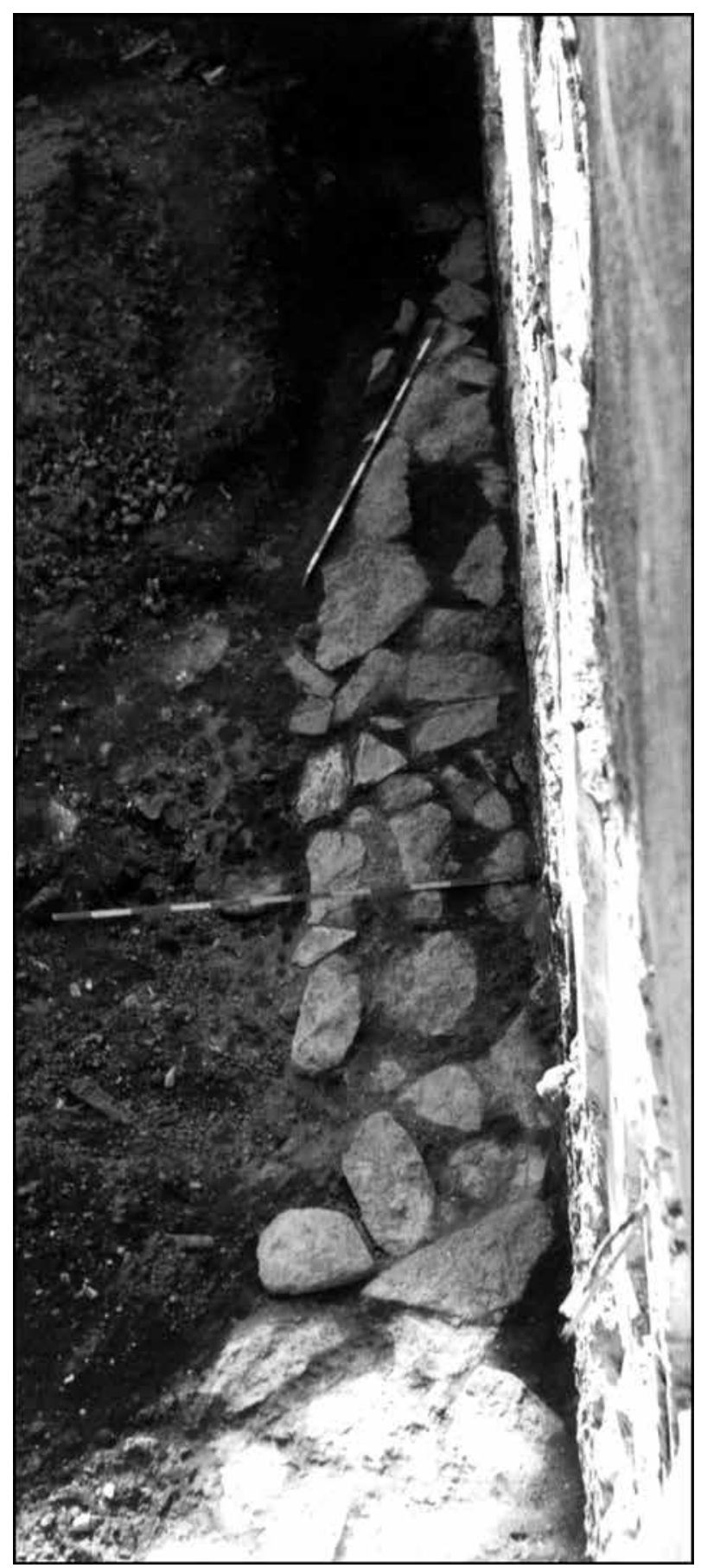

12. kép. A keleti "horreum” maradványai a mai MÁV Székház alatt (Bíró Szilvia és Seres Viktor felmérése alapján szerkesztette Szilasi Attila Botond)

Abb. 12. Die Reste des östlichen „Horreums” unter dem MÁV-Gebäude (Aufgrund der Vermessung von Szilvia Bíró und Viktor Seres von Attila Botond Szilasi gezeichnet) korábban. ${ }^{79}$ A rövid leírás É-D irányú, 110-120, 150, 170, 200, illetve $300 \mathrm{~cm}$ vastag, tégla és vegyes technikával rakott falakról tudósít, amelyek kiterjedését és pontos irányát a $80 \mathrm{~cm}$-es keskeny árokban nem lehetett megállapítani.

A külső támpilléres épülettól 2,6 m-re északra egy az épülettel párhuzamosan futó, bazaltburkolatos utcaszakaszt tártak fel, amelynek déli, azaz az épület felé eső oldalán élükre állított szegélykövek sorakoztak (12. kép). Az út szélességét az egykori ásatási felület keleti metszetfalában sikerült dokumentálni, illetve egy, már az út északi oldalán álló épület kőfala is előkerült. Ezek szerint $4,8 \mathrm{~m}$ (16 láb) széles út rekonstruálható. ${ }^{80}$ A metszetfalban jól látszott a bogárhátszerü kialakítás, ahol a bazaltlapok alatt átlag $20-25 \mathrm{~cm}$ sóderalapozás volt, ez alatt pedig $65 \mathrm{~cm}$ vastagságban vékony sóder- és agyagrétegek váltakoztak. Talán ugyanennek az útnak egy másik szakaszát tárták fel 1893-ban, amikor az akkori Vasmegyei Kaszinó telkén kövezett utat találtak 1,7 m szélességben. ${ }^{81}$

2016 nyarán fotós dokumentációt és új digitális felmérést készítettünk a pincetérben lévô romokról. ${ }^{82}$ Ezek során pontos kiegészítő méretekhez jutottunk, illetve további megfigyeléseket tettünk a fal szerkezetéról.

Ma a MÁV Székház pincéjében a fent említett út egy rekonstruált szakasza ${ }^{83}$ és a külső támpilléres épület egy része látható (13-15. kép). Az épület északi falából már csak mintegy 9 métert lehetett bemutatni (azt a szakaszt, amely a pincebelső területére esett), ebbe a sarokpillér és a következő keleti pillér tartozott bele; a nyugati zárófalából a sarokpillértől délre csak egy 0,75 m

79 Buócz 1968, 53; Buócz T. jelentése, Savaria Múzeum Régészeti Adattár 185. Sajnos sem rajz, sem más képi dokumentáció ezekről nem áll rendelkezésünkre, így az alaprajzon nem tudtuk őket rögzíteni.

80 Ez a méret elmarad mind az ismert kivezető utak, mind pedig a városban lévő fooutak méretétől. A jelen feltárásról keletre az út feltehetőleg kiszélesedik, mivel ott 1901-ben legalább 6 méter széles utat mértek, amely mellett egy csatorna is futott: KoRNISS 1901a, 3.

81 KÁRPÁti 1894, 449. Buócz T. a feltárást a mai Király u. 6. alá teszi (Buócz 1968, 41, ugyanott további leletek listája, amelyek a kaszinó építésekor kerültek elő), azonban korabeli térképeken egyértelmú, hogy a mai Király u.-Kisfaludy u. sarok északi oldalán (a mai MÁV Székház, azaz az 1968-as ásatási területen) helyezkedett el az egykori megyei Kaszinó. Az azonosításhoz köszönöm Derdák Ferenc segítségét.

82 A felmérést Seres Viktor és Bíró Szilvia készítette.

83 Az eredeti ásatási fotók és a jelenlegi helyszínen bemutatott állapot összevetése során egyértelmúvé vált, hogy a látható útszakasz, noha eredeti szinten áll, mégis újrarakott. Az 1968as felvételeken az útszakasz hiányos, szegélykövei sem folytatólagosak. Mindazonáltal a rekonstrukció során eredeti kőanyagot használtak fel, feltehetőleg mindegyik a feltárásból származik. 


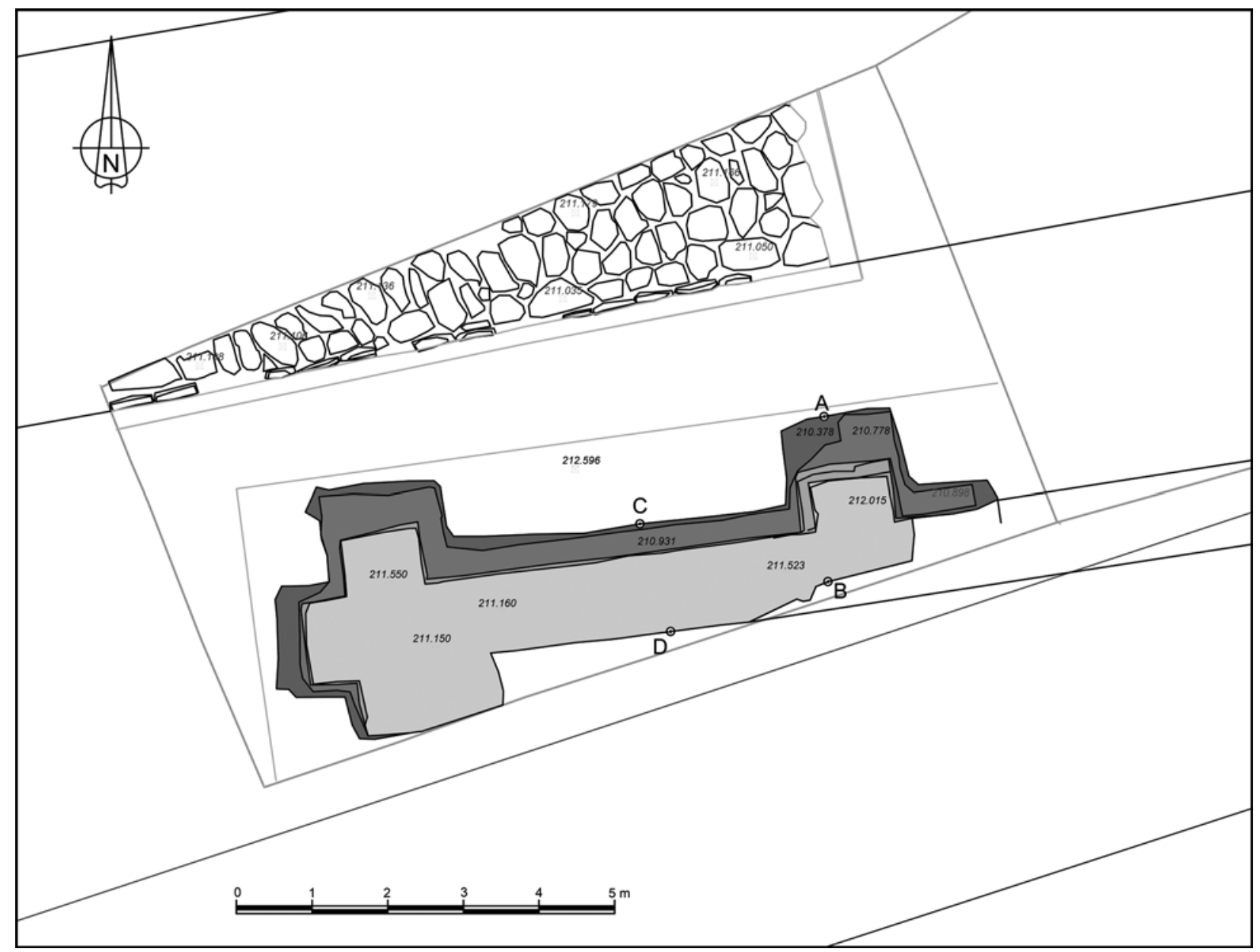

13. kép. A keleti „horreum” támpillérei az 1968-as ásatáson (fotó: Savaria Múzeum Adattár)

Abb. 13. Die Stützpfeiler des östlichen „Horreums” aus der Grabung 1968 (Foto: Archiv von Savaria Museum)

hosszú szakasz maradt meg. A falmaradványok és az útfelület között az egykori járdának megfelelő sávot az újkori építkezés során lemélyítették. A felmenő fal szélessége 1,05 m, megmaradt mérhetó legnagyobb magassága 1,1 m. Az alapozásból 0,55 m magas szakasz látható. Az alapozási zokli szélessége $0,32 \mathrm{~cm}$ a falsíknál, a kiugró támpilléreknél ez 0,5-0,55 m-re nó. Az északi fal megmaradt oldalsó támpillérénél - az 1968-as dokumentációnak megfelelóen - két zoklit lehet megfigyelni (16. kép). A második csak a pillért öleli körbe a szélesebb zokli felett 0,55 m magasságban, a szélessége $0,15 \mathrm{~m}$. A megfigyeléseink közé tartozik, hogy építéstechnikailag a zokli felett egy sor tégla dokumentálható. A falszövet jellegzetesen másodlagos anyagból épült szerkezet képét mutatja, a Savariában a 4. századra jellemző módon kemény, majdnem fehér habarcsot használták. A vegyesen rakott öntött falazat köpenyébe néhány kváderkövet és szürke tufatöredéket is beépítettek.
Az épület keltezéséhez nagyon kevés információ áll a rendelkezésünkre. A gyors feltárás során rétegtani megfigyelésekre nem volt lehetőség, a leletanyag vegyesen tartalmazott $2-4$. századi leletanyagot. Hozzávetőleges datálása jelen állás szerint csak az építéstechnikai jellegzetességek és esetleg az alaprajzi párhuzamok alapján lehetséges. A faragott kövek másodlagos felhasználása és a vegyes kő-tégla falazás alapján a 4 . századra keltezhetjük az épületet. ${ }^{84}$

Topográfiailag a lelőhely Savaria keleti külvárosában helyezkedik el. Sajnos Savaria keleti városfalának pontos vonala nem ismert, de adataink alapján a mai Király utca nyugati házsora alatt húzódhat (10. kép), ${ }^{85}$ így az épület a Király utca és Kisfaludy utca kereszteződésének közelé-

\footnotetext{
84 Fontos megjegyezni, hogy a falsarok belső részén ma egy c. $1,5-2 \mathrm{~m}^{2}$ terület talán érintetlen, ezt a kicsi területet nem bontották vissza a pinceépítés során, így itt a későbbiekben lehetőség van kiegészítő-hitelesítő kutatásra.

85 Medgyes 1998, 88, Fig. 1.
} 


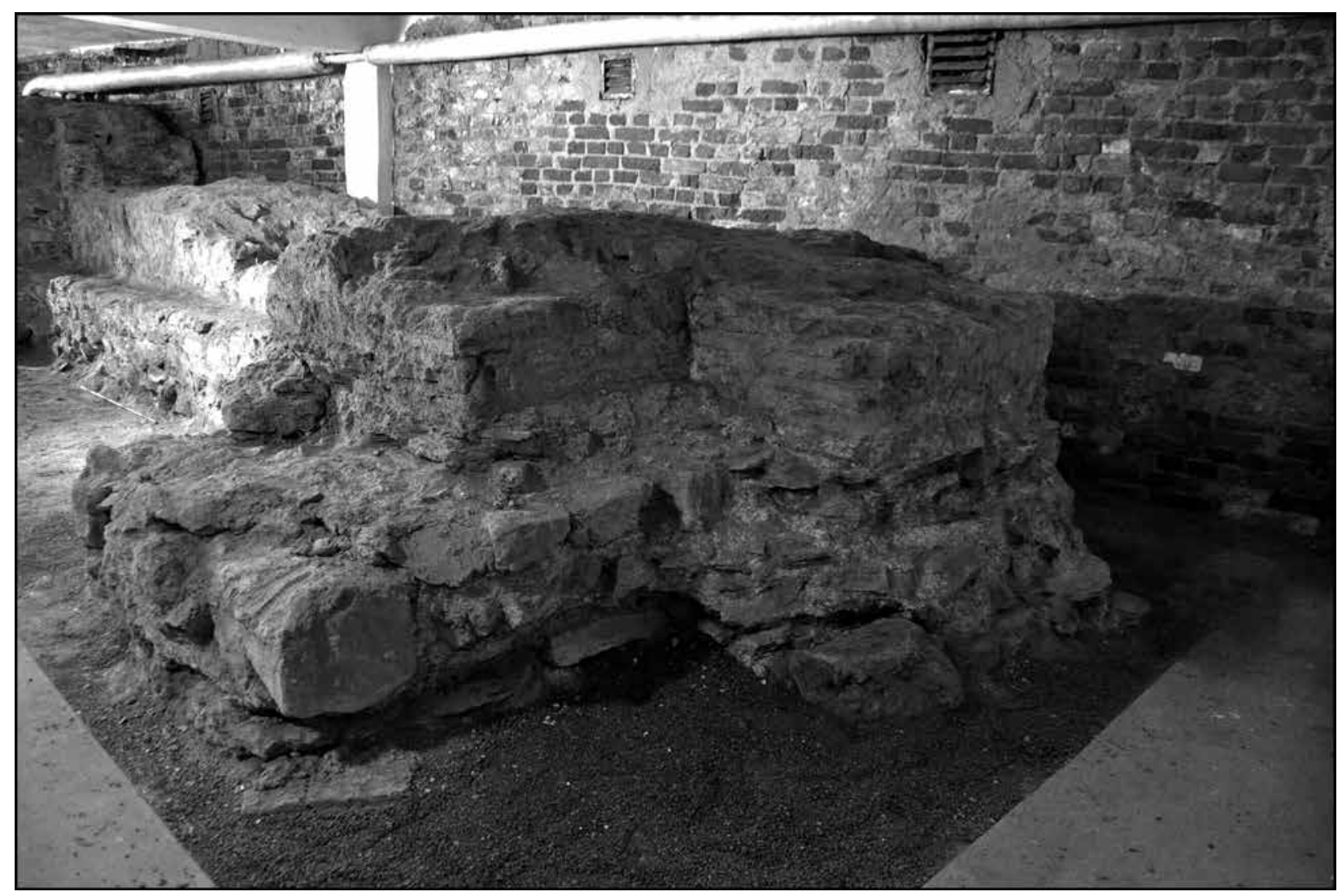

14. kép. A keleti „horreum” ma látható maradványai a MÁV Székház alagsorában nyugat felól (fotó: Sosztarits Ottó) Abb. 14. Die heutigen Reste des östlichen „Horreums” im Souterrain des MÁV-Gebäudes von W (Foto: Ottó Sosztarits)

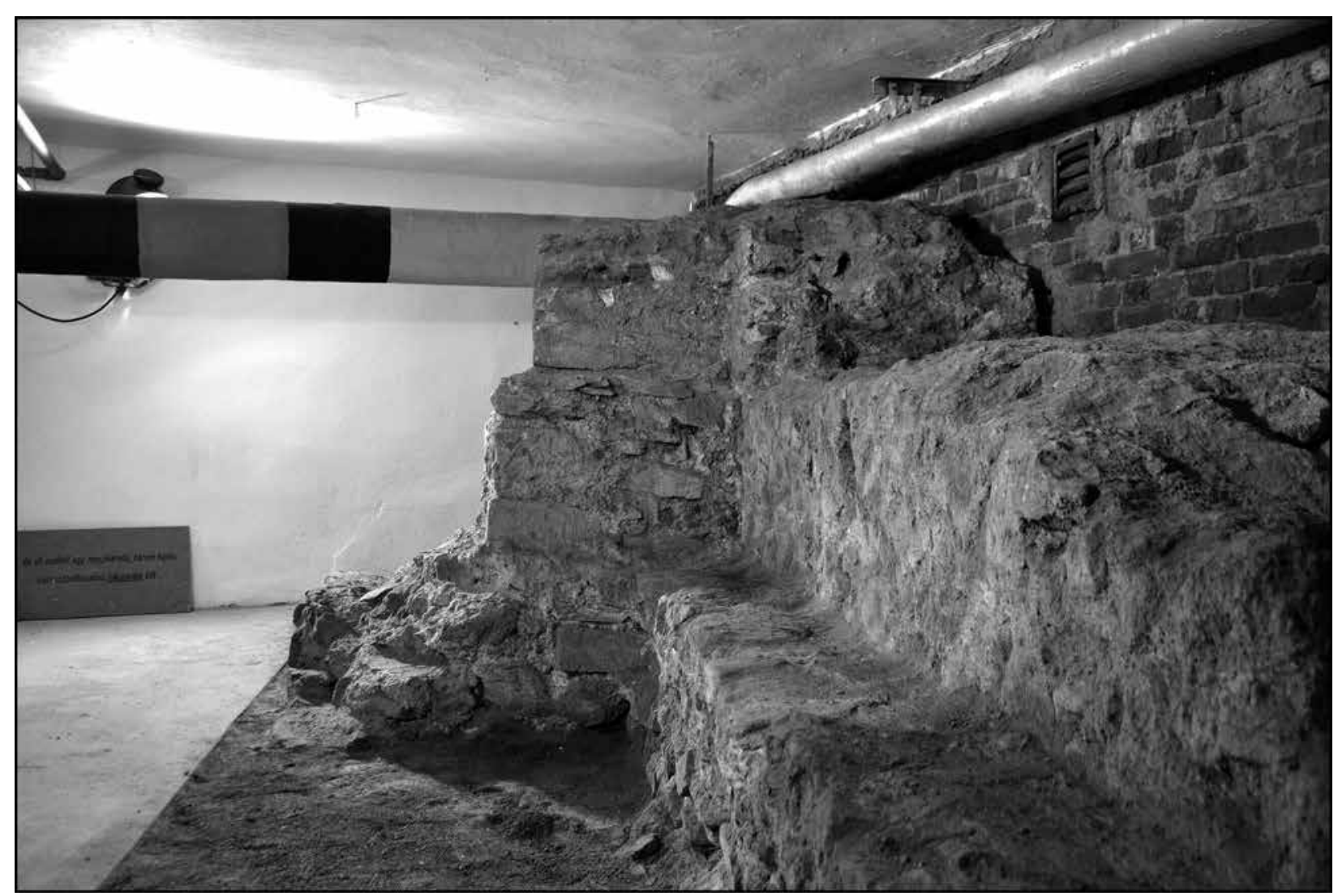

15. kép. A keleti „horreum” támpillére a MÁV Székház alagsorában (fotó: Bíró Szilvia)

Abb. 15. Der Stützpfeiler des östlichen „Horreums” im Souterrain des MÁV-Gebäudes (Foto: Szilvia Bíró) 


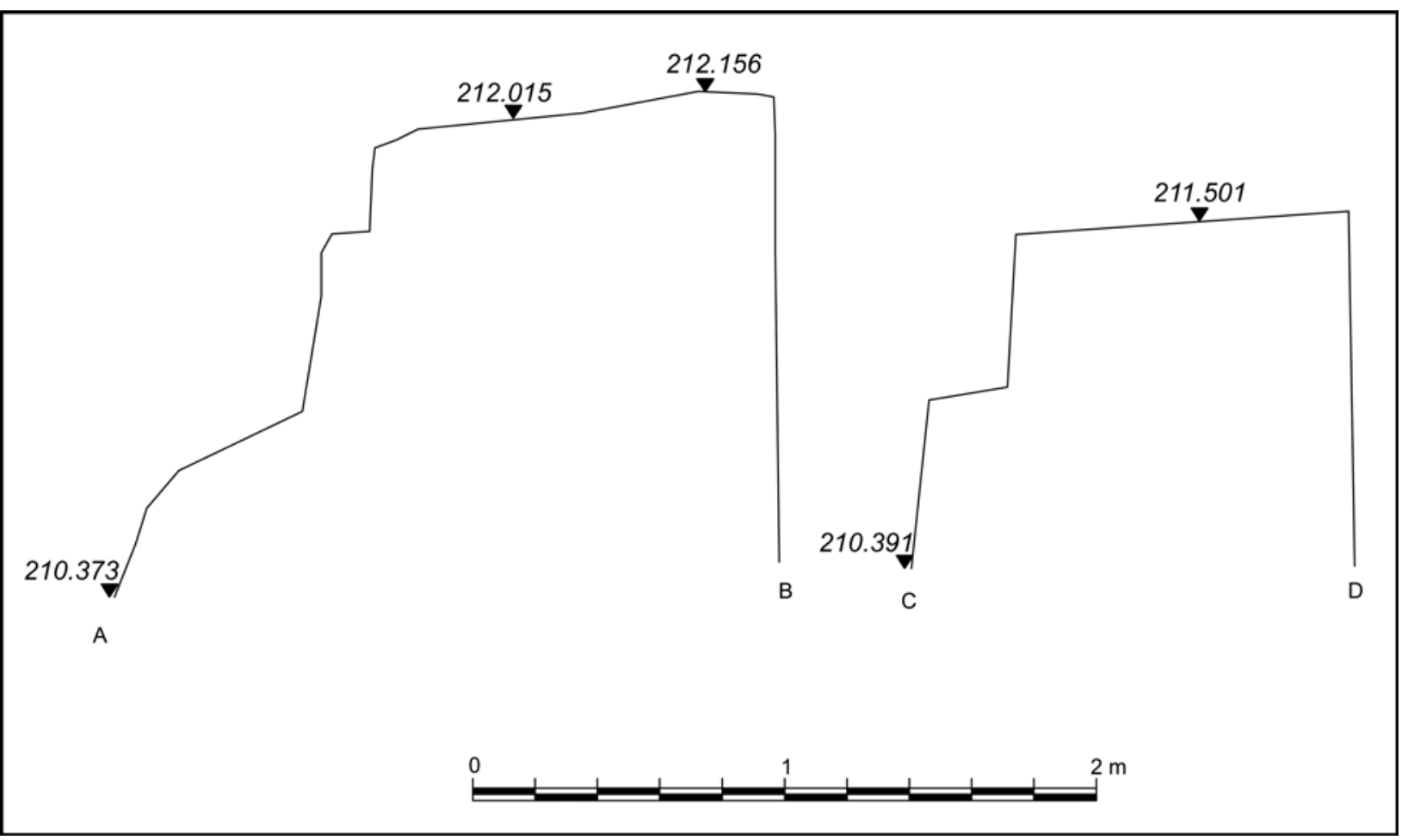

16. kép. A keleti „horreum” falszakaszának metszetrajza (grafika: Szilasi Attila Botond) Abb. 16. Profile der Mauerreste des östlichen „Horreums” (Grafik: Attila Botond Szilasi)

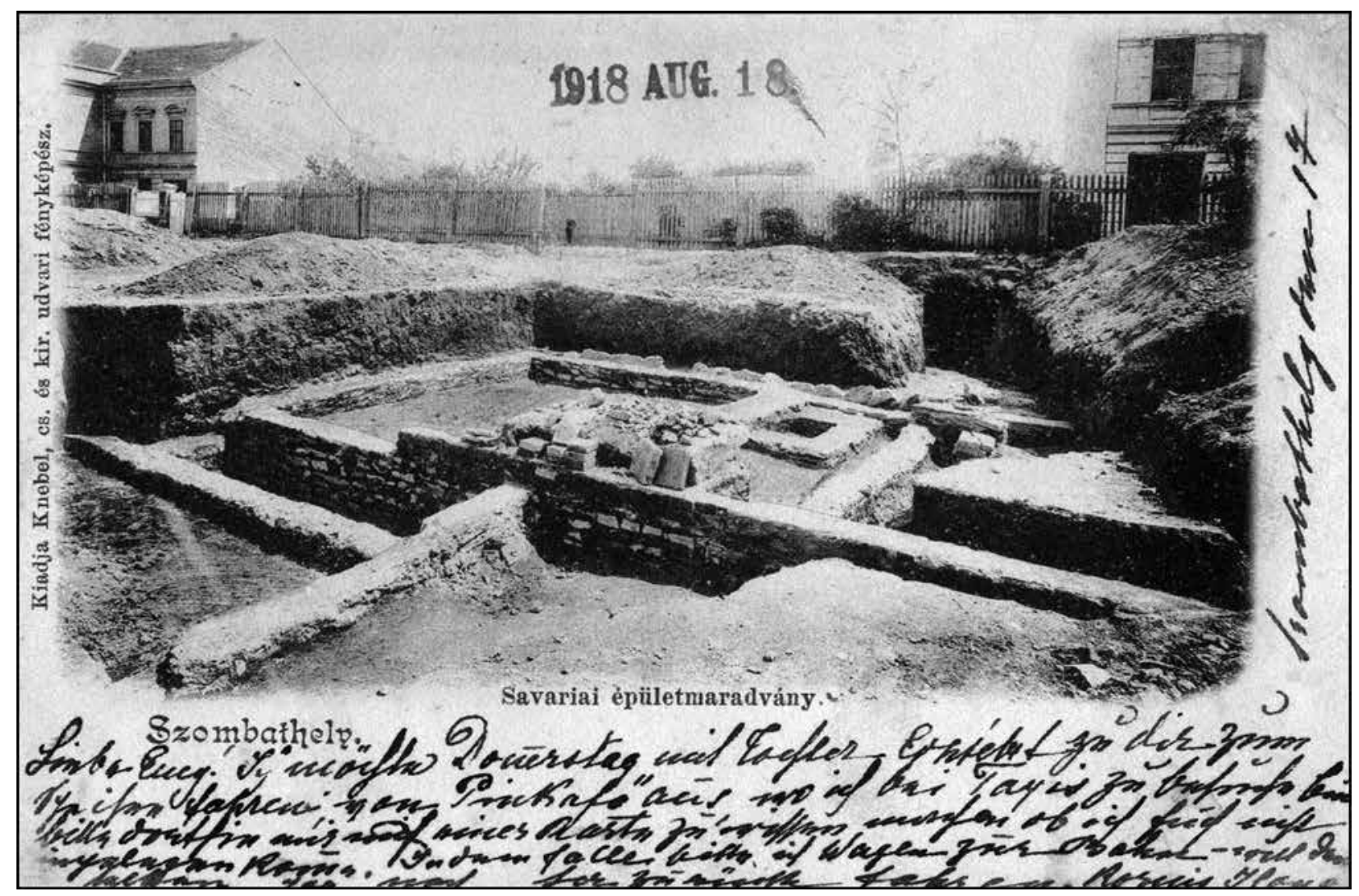

17. kép. A római kori pékség az 1901-es feltárás közben (képeslap Kőszegfalviné Pajor Klára gyújteményéből) Abb. 17. Die sog. Bäckerei während der Grabung 1901 (Postkarte von Klára Kőszegfalviné Pajor) 


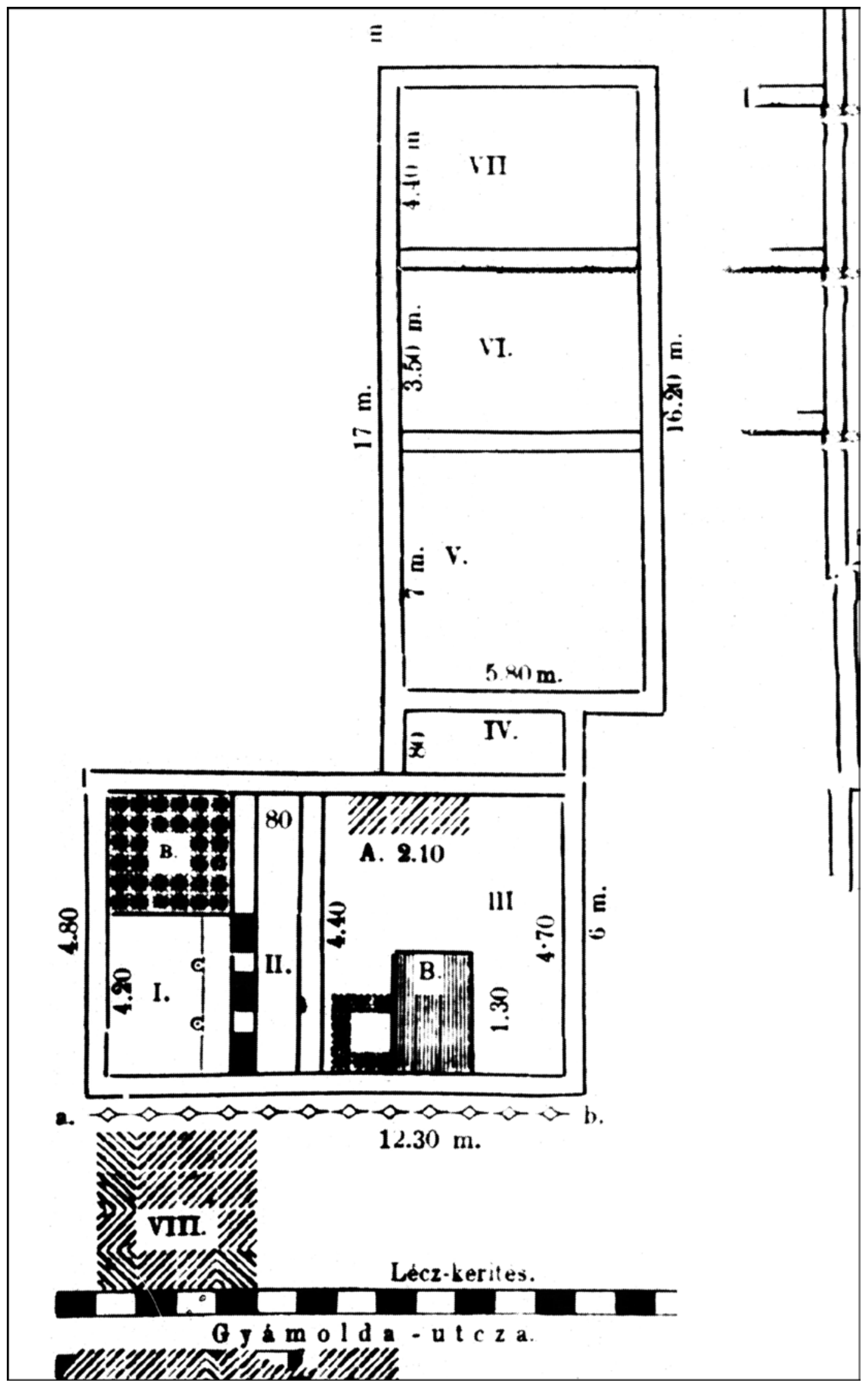

18. kép. A római kori pékség épületének alaprajza (TALABÉR-TóTH 1999, 114, 4. sz. melléklete nyomán) Abb. 18. Grundriss des freigelegten römischen Bäckereigebäudes (Nach TALABÉR-TóTH 1999, 114 Beiblatt Nr. 4) 
ben lokalizálható kapu közvetlen szomszédságában, a város tengelyében futó kelet-nyugati út városfalon kívüli szakasza mentén helyezkedik el. Ez a kivezető út azonban nem az Arrabona felé haladó, majd a limesútba csatlakozó foút volt, mivel az a város DK-i sarkából indult, és a keleti (ún. Szt. Márton-) temetôn át vezetett a dunai tartományhatár felé.

A feltárt és horreumként értelmezett épület, valamint a fentebb ismertetett felirat közötti öszszefüggés lehetôségét Tóth Endre vetette fel. ${ }^{86}$ Érdekes módon Buócz Terézia, a Kisfaludy S. utcai horreum feltárója nem az oáltala, hanem az Iseumtól délre fekvő horreummal hozta összefüggésbe a feliratot. ${ }^{87}$

Hasonlóan a városfaltól délre elterülő horreumhoz, ennek környékén is ismerünk gabonafeldolgozáshoz kapcsolható egyéb jelenséget. A Kisfaludy utca (akkori Gyámolda utca) északi oldalán egy a 20. század elején üresen álló telek régészeti kutatásáról szólnak korabeli feljegyzések (17. kép). ${ }^{88} \mathrm{Az}$ ásatás lokalizálása mindenképpen a fenti horreumtól északkeleti irányba eső, ma valószínúleg szomszédos ház telkének területére tehetó. A 1901 májusában folytatott kutatások eredményeképpen két méterrel a felszín alatt egy római kori épület maradványai bukkantak fel. Tóle délre egy hat méter széles lekövezett utca került elö, amely a saroktelken megfigyelhető K-Ny irányú útszakasz keleti folytatásaként értelmezhető. A nagyobb, feltehetőleg bazaltkő lapokkal lefedett út déli oldala már az akkori úttest alá esett, ezért ott a kutatás nem volt lehetséges. Az épületet a korábbi közleményben még kovácsmúhelyként határozták meg, azonban a későbbiekben a feltáró Korniss Emil gróf már inkább pékmúhelyként értelmezi (18. kép).

„...ezt igazolja az I. számú sütőkemencze, mely egy körfallal két részre volt osztva és a III. számu helyiség közepén 8 négyzetméter területen elszórva és helyen-helyen $10 \mathrm{~cm}$ vastagságban talált elszenesedett búza és rozsmaradvány. Ezen terület keleti részén találtam elszenesedett árpát, zabot és bükkönymagot is, mely utóbbin még annak tokja is látható. Hogy ezen épület tüz által pusztult el, bizonyítja a számos szenesedett gerenda részlet, melyek közül úgy a tölgy, valamint a fenyöfa könnyen felismerhetô. A III. számú üzlethelyiség mellett a II. sz. egy keskeny folyosó, vagyis fütőhelyiség

86 Korábban horreumként jelölve: HAJNÓCZI 1987, 64, 55. ábra; HAjNÓCZI-MEzős 1995, 16. térkép, 21; illetve a Rufinus felirathoz kapcsolva: KISS-TóTH-ZÁGORHIDI CZIGÁNY 1998, 50.

87 Buócz 2003, 58.

88 KoRNISS 1901a; KorNiss 1901b (lásd még: TALABÉR-TóTH 1999, 33, No. 69, 34-35, No. 76). van. Az A-val jelölt téglafalazat az üzlethelyiség asztalát képezte. A B-vel jelölt területek téglapadozatok. Ezen helyiség padlója mésszel kevert sárga szinü tömés volt, ily szinü padozat van az V-ik számu helyiségben is, ellenben a VI. számu lakosztály vörös, 15 centiméter vastagságu terazzóval van burkolva és simára csiszolva. A VII-ik számu helyiség, ezektól eltéröleg, durvább rostált kavics törmelékkel, 18 centiméter vastagságban van padlózva, ellenben a két folyosóban a padozat hiányzik. A 30 centiméter vastagságu alapfalak arra engednek következtetni, hogy ezen épületeket szegényebb sorsú sorsu emberek lakták. A felépitmény, melynek egyes részei feltaláltattak, későbbi időkben épitkezési anyagul felhasználtattak, ezek közt igen érdekes mintázott és sima falfestményi töredékek is voltak, melyek a vagyonosabbak épületeiből kerülhettek ide. Ezen törmelék között gyéren elszórva rézpénzek is találtattak többnyire Constantin verettel." 89

Sajnos semmilyen egyéb feljegyzés nem áll rendelkezésünkre a feltárásról, csak korabeli képeslapok. ${ }^{90}$ A telket azóta beépítették, egy többemeletes épület áll rajta ma is, így a fenti leírás pontosságát és a meghatározás helyességét nem lehet igazolni.

\section{Városi horreumok Pannoniában}

Pannonia városias környezetéből viszonylag kevés horreumot ismerünk.

Scarbantia (Sopron) forumának nyugati oldalához kapcsolódóan sikerült lokalizálni egy horreumot. A mai Fő téren álló Szent Háromságszobor nyugati oldalán egy 14 méter széles, belső pillérsoros épület 3 pillére került elő. Keltezését tekintve késó római, mindenképpen a városfal megépülése utánra tehetó, és egy kora római szentély felett állt. ${ }^{91}$

Topográfiai és kronológiai párhuzamként a késő római nagyobb városok (fóvárosok) helyzetét kell leginkább megvizsgálni. Elsô helyen Sopianae városát kell megemlíteni. Pécs ókori elődje Savariához hasonlóan a korábbi tartományok felosztása révén vált helytartói székhellyé. A korábban városi ranggal nem rendelkező település (vicus) municipium rangja megadásának dátuma sem ismert. ${ }^{92} \mathrm{Az}$ újonnan kialakított Valeria tartomány székhelye lett, élén a praeses

89 KoRNISS 1901b.

90 A képeslap rendelkezésünkre bocsátását ezúton köszönjük Kőszegfalviné Pajor Klárának.

91 GÖMÖRI 2003, 86, illetve GÖMÖRI 2013, 221; a horreum topográfiai helyét és vázlatos alaprajzát rögzíti: 2. és 7 . ábra, a pillérek metszete: 12 . ábra.

92 Összefoglalóan VISY 2013, 135-136. 
állt. A városban a savariaihoz hasonló intenzív építkezések figyelhetők meg. ${ }^{93}$ Ezek részeként a város déli szélén, a városfal közelében, a településről dél felé kivezetố út nyugati oldalán nagyméretú, 22 méter széles, hossznégyszögú épület állt a mai Nagy Lajos király útja térségében. A horreumot egy korábbi bazilika részleges felhasználásával Kr. u. 340 után hozták létre. ${ }^{94}$ Négy sorban 7-7 pillérrel tagolt belső tér és külső támpilléres határolófalak jellemezték.

Siscia városában is nagyarányú, a 4. századra keltezhető monumentális épületeket dokumentáltak, köztük közvetlenül a városfal belső oldalán, egy saroktorony mellett egy horreum helyezkedett el. A $120 \mathrm{~cm}$ széles falakat kívülről szabályosan sorakozó támpillérek erősítették, belül kétszer négy pillérsor tagolta a teret. A 21 méter hosszú épület szélessége nem ismert. Építéstechnikai hasonlóságot mutat savariai épületünkkel a vegyesen rakott falazat, benne másodlagosan felhasznált kövekkel, illetve az alapozást és a felmenő falat elválasztó téglasorok. ${ }^{95}$

Közigazgatási szerepe miatt Sirmium érdemel kiemelt figyelmet. Pannonia Secunda fóvárosaként vélhetően a praefectus praetorio Illyrici székhelye is volt, rezidenciális szerepe egészen az 5. század első harmadáig megmaradt. ${ }^{96} \mathrm{~A}$ város területén több horreumot is feltártak.

A 4. században a déli városfal közvetlen szomszédságában, de a városfalon belülre lokalizálható egy két épületból álló horreum. ${ }^{97}$ Egy korábbi, a 2-3. században már ugyanazon a helyen, ugyanazon funkcióval bíró épület helyén építik újjá. ${ }^{98}$ Bár az épületek csak részlegesen kerültek feltárásra, alaprajzuk rekonstruálható.

$\mathrm{Az}$ „A" $\mathrm{A}$ " épületet közvetlenül a 2-3. századi déli városfalhoz építették, belső mérete 10,5×40 méter. Az épületet belül egy pillérsor osztotta ketté, és azok mentén kisebb, könnyú szerkezetú helyiségekre volt felosztva, ahol egy helyiség $5 \times 5$ méteres volt. Csak a külső rövidebb zárófalain volt 3-3 külső támpillér megfigyelhetó.

A 3. század végi, 4. század eleji gyors fejlódés további raktárépületeket tett szükségessé. A korábbi városfalat c. 35 méterrel délebbre tolták, így

\footnotetext{
93 Az építkezések intenzitására: NAGY [2017]; az épület helyére vö. Visy 2013, 137-143; KovALitzKY-TótH 2014, 84, Abb. 8. A fal vonalára uo. 58. jegyzet. Amennyiben a szúkebb város/ északabbra futó déli városfal topográfiai szituációt fogadjuk el, a gabonaraktár helyzete teljes mértékben megegyezik a többi ismert, igazgatási központban lévő horreuméval, azaz közvetlenül a városfal mentén állt. Lásd alább.

94 Tо́тн Zs. 2009; То́тн 2010, 102-109.

95 LOLIĆ 2003, 142-143, Fig. 20-23.

96 Mirković 2004, 150-151.

97 Popović 1993, Fig. 4. No. 3.

98 PopOVIć 1993, 20-24.
}

maradt hely egy további horreumnak („, $B^{\prime \prime}$ épület). A 85×33 méteres épület közepén egy hosszú folyosó helyezkedett el, amelyről kisebb hosszúkás helyiségek (c. 5×9,5 m, 4,6-4,8×10 m) nyíltak. Bejárata a császári palota felől volt. ${ }^{99}$

A horrea topográfiai helyzete figyelemre méltó: a városfalon belül, a császári palotától 100-150 méterre található, de valószínúleg az épületkomplexum részét képezte.

A város másik horreuma a Licinius nevéhez köthető fürdőtől délre található. A horrea publica két fóút találkozásánál, a feltételezett forum nyugati határán terül el. A 3. század végén, 4. század elején építették, trapezoid alaprajzú (c. $44 \times 22 \mathrm{~m}$ ). Helyén korábban is épület állt, erre utal a legalább 10 korábbi pillérmaradvány az épületen belül. A későbbiekben belül $4 \times 6$ pillér sorakozott, a zárófal belső oldalán pedig végig támpillérek. Kívülről csak három oldalon álltak támpillérek, a negyedik oldalról egy előcsarnok tartozott hozzá, a rekonstrukciók alapján kétszintes lehetett. Az épületet kívülről árkádsor vette körbe. ${ }^{100}$

$\mathrm{Az}$ újabb horreumok (át)építését részben a közigazgatási feladatok megnövekedésével, illetve a 4. század elején megszaporodott császárlátogatásokkal kapcsolják össze. ${ }^{101}$

Brigetio jogi értelemben nem városi rangú canabéjában elmúlt években két horreumot tártak fel, ${ }^{102}$ melyek azonban kronológiájukat tekintve nem használhatók fel párhuzamként, mivel késő római gyermeksírok voltak bontási planírrétegükbe ásva.

A pannoniai horreumok említése során mindenképpen utalni kell a katonai környezetben előforduló nagyszámú raktárépületre, amelyek viszont egyértelmúen a limes menti katonaság ellátását biztosították. A késő római katonai átszervezések következtében az ellátás biztosítása - legalábbis részben - már nem közvetlenül a csapatok állomáshelyén történt. A 4. század első harmadában épített belső erődök - és bennük a horrea - a katonaság ellátását biztosították, „el-

99 JEREMIĆ 1993a, 100-103, bes. fig. 33 (további irodalommal); MirKOVIĆ 2004, 154, Fig. 5.

100 JeREMIĆ 1993b, 113-114, Fig. 41 (korábbi irodalommal). Az ún. Licinius-fürdő építését Licinius Kr. u. 306-314 közötti látogatásával hozzák összefüggésbe (CIL III 10107).

101 Popović 2013, 108-109. Míg a császárok a 3. sz. legvégén és a 4. sz. legelején csak rövid időre látogattak a városba, Licinius családjával 308-316 között szinte folyamatosan itt tartózkodott (Excerpta Valesiana V,17; Zosimos II,19). Később Constantinus is sok időt töltött a városban: 319 márciusában érkezett, és az év végéig maradt, majd 321. április, június, szeptember, 322. június, július, 323. május, 324. január, 326. április, május, december, 329. március hónapokban dokumentálható az ittléte.

102 Bartus-Borhy-SzÁmadó 2015, 247, Fig. 12-16. 
látó bázisok, logisztikai központok" voltak. ${ }^{103}$ Ezek alaprajzilag nem különböznek a fenti bemutatott példáktól, külső támpilléres épületek, amelyek belsejét általában két sor pillér osztotta három hajóra. ${ }^{104}$

\section{Horreumok más igazgatási központokból}

A Római Birodalom más nagyobb városaiban is jól dokumentálható horreumépítkezéseket ismerünk a késő római időszakból. A következőkben a legjobban ismertek közül mutatunk be néhány jellemző példát.

Augusta Treverorum (Trier) a késő római időszakban kiemelt igazgatási központ, császári központ, a praefectus praetorio Galliarum székhelye volt. ${ }^{105} \mathrm{~A}$ késő constantinusi időktől bizonyítható, hogy a 14 insulányi császári épületkomplexum közelében, a város ÉNY-i sarkában épült egy horreum (Szt. Irmina). Két egymással párhuzamos csarnokból állt (egyenként $70 \times 20$ $\mathrm{m})$, belül két sor pillérrel, amelyeket egy középső folyosó (12 m széles) választ el. Az alapfalak mindkét oldalán támpilléreket lehetett megfigyelni, amelyeket árkádos kialakításúként rekonstruálnak, ahol egy-egy árkádív alatt ablaknyílás helyezkedett el. A falszélesség 0,95 m; 4-6 jurai mészkövekból álló sor után egy kétrétegú téglakiegyenlítő sáv következett, ezek a téglasorok 0,7-0,8 méterenként követik egymást. Falába korábbi épületelemeket építettek be másodlagosan, és legalább kétszintes lehetett. ${ }^{106}$

1993-1996 között az épülettől 28 méterre keletre további ásatások során egy másik horreum került elő. ${ }^{107}$ Legalább 64 m hosszú, illetve ha a korábban ismert falmaradványokkal össze lehet hozni, akkor akár 100 méter hosszú is lehetett, és egy nyitott udvar választotta el az elóbbitől. A 0,6 m széles falak szerkezete hasonló a fentihez, téglasorokkal tagolt. Belül $18 \mathrm{~m}$ széles, és egy sor pillér fut középen, ezért csak egyszintesként rekonstruálják. A déli falát egy a 3. század utolsó harmadában felhagyott épület maradványaira rakták. A horreumot csak a 4. század későbbi szakaszában építették, de használata egészen a 4. század második feléig bizonyított. A horreum

103 То́тн 2009, 78. A jelenségre más birodalmi példákkal és az írott források említésével: BORHY 1996, 207-223.

104 Eddig Ságvárról (Тóтн 2009, 32-34), Alsóhetényből (ТóтH 2009, 47-48), Fenékpusztáról (HeInRICH-TAMÁsKA 2011, 679681). Itt kell megemlíteni még a Pilismarót (SOPRONI 1978, 36-45) és Tokod (Mócsy 1981, 39-40) erődítésében levő horreumokat is.

105 LUIK 2001, 247.

106 EIDEN 1949, 73-98; CLEMENS 2001, 169-171, főleg Abb. S. 170.

107 LUIK 2001, 278-280. építésekor a korábbi falakat elbontották és elplanírozták, kiegyenlítették a területet. Topográfiailag a városfalhoz közel, egy belső városi út mentén fekszik, amely a Mosel partján levő kikötővel is kapcsolatot teremtett. ${ }^{108}$

Aquileia városa a comes Italiae, praepositus thesaurorum Venetum és a praefectus classis Venetum székhelye volt a 4 . századtól kezdve. A Constantinus-korban főleg az észak felé irányuló hadi cselekmények kiindulópontja és így császári tartózkodási hely is. ${ }^{109} \mathrm{~A}$ megnövekedett lakosságszámhoz és feladatokhoz mérten a 4. század folyamán nagyarányú építkezések figyelhetők meg: a forumtól DK-re, a város szélén új központ épül, benne püspöki palotakomplexummal, horreummal, kikötőhellyel, amely a korábbi forum funkcióját is jórészt átveszi. ${ }^{110}$ A horreumot egy korábban itt álló épület helyére építik, mérete c. $66 \times 89$ méter volt és 15 méter magas. A trierihez hasonlóan két K-Ny-i tájolású épület egy hosszú belső udvarral van összekapcsolva. Külső támpilléres volt árkádos lezárásokkal. Funkciójára a belsejéból származó nagy mennyiségú elszenesedett gabonamaradvány utal. ${ }^{111}$

Mediolanum (Milánó) Maximinianus uralkodása alatt vált közigazgatási központtá, ennek megfelelően a 3 . század végén, a 4. század elején nagy építkezési hullám figyelhető meg a római város területén: a nyugati városrészben circus és palatium, az északnyugatiban horreumok és thermae épültek. A horreumok az ÉNY felől bejövő út (Bergomum és Comum felól) közelében a városon belül feküdtek, de viszonylag közel vannak a városfalhoz. ${ }^{112} \mathrm{~A}$ Via dei Bossi 4. sz. alatt feltárt raktárépület $23 \times 68 \mathrm{~m}$ nagyságú, belső pillérsorok négy hajóra osztják. A középső pillérsor nagyobb méretú, mint a két oldalsó. Kívülról feltehetóleg szintén árkádos lehetett a támpillérsor, amelyben ablaknyílások biztosították az épület belsejében a fényt. Elképzelhetó, hogy ez is olyan kettős volt, mint a trieri vagy az aquileiai; erre utal, hogy a főfalak futnak tovább. Keltezése Maximinianus-kori. ${ }^{113}$

A mellette fekvő Via del Laurón egy másik horreum ismert. Ez a köztársaságkori városfalon kívül, de a Maximinianus-kori városfalon belül található. Csak egy falszakasz van meg belőle,

\footnotetext{
108 Clemens 2001, 171-173.

109 HaUg 2003, 86.

110 HaUg 2003, 169.

111 Mirabella Roberti 1965, 45-71; Haug 2003, 337-338, Taf. 48, ÖR 15.

112 HaUg 2012, 113-115, Abb. 1.

113 HAUG 2003, 421, ÖR 7.
} 
horreumként való azonosítása kétséges. Az építése 4 . századi, topográfiai helyzete miatt inkább a Maximinianus-kor utáni. ${ }^{114}$

Iulia Concordia (Concordia Sagittario) horreumait topográfiai helyzetük miatt emeljük ki: az egyik a városból délkelet felé kivezetó út mentén, közvetlenül a városkapu közelében helyezkedett el, míg egy másik a városfalon belül, de közvetlenül amellett. ${ }^{115}$ Fontos hangsúlyozni, hogy a városfalon kívül fekvő horreum már a Kr. u. 1 . század folyamán létesült, és a következő évszázadokban helye és funkciója változatlan maradt.

A tetrarchia időszakában a legtöbb és legnagyobb méretú horreumok városi környezetben a Balkánon találhatók. 116 Általánosságban elmondható, hogy elsősorban a városkapuk környékén, a bevezetó utak mentén helyezkednek el. A horreumok leginkább magányosan állnak, de előfordulnak csoportosan is, és egyes helyeken egész raktárkörzetet sikerül dokumentálni. Istrius (Istria, Románia) ${ }^{117}$ városában a városfal mentén helyezkedik el négy raktár egymás közvetlen közelében. A város feltehetőleg élelmiszerellátásban kiemelt szerepét hatalmas kikötője biztosította, amely esetleg a keletről érkező szállítmányokat is fogadta. Egy különleges, eddig ismert párhuzam nélküli megoldás található Dacia Mediterranea központjában, Serdicában (Szófia, Bulgária). Itt a megerősített város délnyugati sarkában, közvetlenül a városfalak tövében nyolc azonos méretú és kivitelú, egymás mellé épített raktárépület alkot szabályos "horreumutcát”. ${ }^{118}$ Másik csoportot képviselnek azok a horreumok, amelyek egyértelmúen a település központjában, sokszor a forum/agora közvetlen közelében találhatók, így Nicopolis ad Istrum (Nikjup, Bulgária) esetében, ahol az agora északi oldalán helyezkednek el. ${ }^{119}$ További példával szolgálhat Tropaeum Traiani (Adamclisi) esete. A várost 315/317-ben építik újjá császári utasításra, és a település közepén, ott, ahol a forum rekonstruálható, egy horreum helyezkedik el. ${ }^{120}$ A trieri és mediolanumi kettős horreummal mutat párhuzamot a Municipium DD (Sočanica, Koszovó) forumán feltárt raktárépület is. ${ }^{121}$

A késő római időszak igazgatási központjaiból ismert horreumok bemutatása alapján jól látszik,

\footnotetext{
114 HAUg 2003, 421-422, ÖR 8.

115 Croce Da VILla 2006, 212, Abb. 1.

116 Rizos 2013, 671-680.

117 Rizos 2013, 674-675, Fig. 16.

118 Vö. Динчев 2005, 292, Fig. 2; Rizos 2013, 677-678, Fig. 21.

119 Rizos 2013, 675-676, Fig. 19.

120 POULTER 1992, 117. Az épület funkciója sokáig vitatott volt, lásd ehhez Rizos 2013, 672-673, Fig. 13.

121 Rizos 2013, 679.
}

hogy markánsan elkülönülnek a császári székvárosok (Augusta Treveriorum, Mediolanum, Aquileia), amelyek egyben a katonai ellátás legfontosabb centrumai voltak. Az itt feltárt horreumok mind méretben, mind kivitelben különböznek a többi hasonló létesítménytől. ${ }^{122}$ Jellegzetességeik a hatalmas, eddig jobbára csak katonai erődítményekben, kikötőkben vagy birtokközpontokban mutatkozó, gyakran 60-80 méter hosszúságot is elérő építmények.

A városok területén a 4 . században épített raktárépületek száma feltúnóen magasabb, mint a korábbi időkben ismert horrea száma. Ezt a legtöbb kutatás általában a városok megnövekedett szerepével és a katonai ellátásban való részvételükkel indokolja. ${ }^{123}$

\section{A savariai horreumok lehetséges értelmezése}

Nagyméretú raktárépületek, horreumok bizonyára már a korábbi évszázadokban is álltak Savariában, ezek elsősorban a város lakóinak ellátását szolgálták. A helyzet a Kr. u. 3-4. század fordulóját követóen változott meg lényegesen. Az új tartományszékhely felduzzasztott hivatali apparátusa, illetve a védelmükre kirendelt katonaság önmagában is a már meglévő tárolókapacitás növelését igényelte. A 4. század utolsó harmadától kezdve birodalomszerte további építkezésekre került sor, amelyek az egyre bizonytalanabb helyzetben éló lakosság biztonságos élelmiszer-ellátását (is) szolgálták. A 4. századi horreumépítkezések meghatározó motívuma azonban a tartományszékhelyi státuszból fakadó feladatok lehettek.

A Septimius Severus által bevezetett annona militaris szervezése a 4 . század elejétől a Savariában székeló praeses alá tartozó egyik schola feladatává vált. ${ }^{124} \mathrm{~A}$ tartomány területén megtermelt és begyújtött élelmiszert a fóvárosba, Savariába szállították, ahonnan azt a határon állomásozó haderő (limitanei), illetve a tartomány belső katonai egységeihez szállították. Az átmenetileg Savariában tárolt gabona és egyéb élelmiszer további raktárépületek megépítését igényelte, ami nyilvánvalóan nem ment egyik napról a másikra, és a késóbbiekben is akadhattak zökkenők. A Rufinus-felirat tanúsága szerint az infrastruktúra kiépítése és múködtetése terén mutatkozó zavarok a helytartó felett álló praefectus praetorio személyes beavatkozását igényelte.

\footnotetext{
122 Vö. Whately 2013, 212.

123 Haug 2003, 72-73; Rizos 2013, 680.

${ }^{124}$ E kérdéssel Nagy Tibor külön is foglalkozik tanulmányában: NAGY [2017].
} 
A fent említett birodalmi párhuzamok is azt látszanak alátámasztani, hogy a katonai ellátásban való részvétel új feladatként jelenik meg a városok esetében, és több, ebben az időben regionális és/vagy tartományi központtá váló település területén figyelhető meg horrea-építkezés. ${ }^{125}$

A Rufinus-felirathoz jelen ismereteink szerint nem tudunk biztonsággal épületet rendelni, de a felirat többes számban említ raktárakat (horrea), így akár több, egymás közelében álló épület is szóba jöhet. Hogy ezek a horrea elszórva vagy csoportosan helyezkedtek el a város területén, bizonytalan. A kőemlék lelőhelyének bizonytalansága miatt azt is csupán vélelmezni tudjuk, hogy a város keleti oldalán állhatott (vagy állhattak), és még azt sem tudjuk eldönteni, hogy a fal külsó vagy belső oldalán kell-e keresünk óket. A MÁV Székház alatt megtalált nagyméretú, külső támpillérekkel megerősített épületet - bár rendelkezik néhány, a horreára jellemző építészeti sajátossággal - az épületbelsó ismerete nélkül nem lehet teljes biztonsággal (gabona)raktárnak meghatározni. E tekintetben a közvetlen közelében egykor állt pékség léte sem perdöntő bizonyíték. Így ezt az épületet a kutatás jelen állásában csak feltételesen, erős megszorításokkal nevezhetjük horreumnak.

A MÁV Székház alatti keleti „horreum” méretét, belső szerkezetét a két megmaradt rövidebb falszakasz alapján nem lehet megállapítani (10. kép). Tájolása sem ismert. A kivezetó úttal párhuzamos, hosszanti fekvése esetén hosszúsága maximum 30-32 méter lehetett. ${ }^{126} \mathrm{Az}$ útra meróleges, haránt elhelyezkedés esetén a (déli horreuménál némileg vastagabb, az egy métert meghaladó) falvastagsága akár egy nagyobb épület létét is megengedi. Mivel az északi oldalfal megmaradt két támpillére között a felmenó szerkezetben nem látható falnyílás, így bejárata(i) nem ismeretes(ek).

Más a helyzet az Iseum déli oldalán feltárt objektummal. Az épületet - a leírt bizonytalanságok ellenére - horreumnak, ezen belül leginkább granariumnak tarthatjuk (4. kép). A korhatározás azonban egyértelmúen kizárja, hogy a létesítményt Vulcacius Rufinus 344 és 347/349 közé datálható építkezésével hozhassuk összefüggésbe. Az ásató Cserményi Vajk által javasolt viszonylag késői, 360-380 körüli keltezést a ma még nem lezárt ásatásunkon tapasztaltak mel-

\footnotetext{
125 Vö. RizOs 2013, 679.

126 Tőle keletre egy többhelyiséges épület állt, amelyet falazástechnikai jellegzetességei és az előkerült II. Constantinusérmek alapján feltételesen 4. századinak lehet gondolni: Horváth Tibor Antal naplója a Savaria Múzeumban, térképre helyezte Derdák Ferenc. (Lásd még: Buócz 1968, 53).
}

lett több közvetett érv is erôsíti. Az épület létrehozása azonban már nem indokolható egyértelmúen az annona militaris tárolásának megnövekedett igényével, hiszen az annona időközben lényegesen visszaszorult, Valentinianus idejében már a comitatenses is pénzben kapja meg az ellátmányt vagy annak egy részét. ${ }^{127}$ A horreum építésének lehetséges okát tehát másban kell keresnünk.

Már az Iseum terepi kutatása során felfigyeltünk arra a jelenségre, hogy az Isis-szentélyt és a környékén - így a Borostyánkő út keleti oldalán is - korábban ott álló épületeket (legalább részben) elbontották, helyüket elplanírozták, a kinyert építóanyagot újabb épületek létesítéséhez használták fel. A déli horreum területén - részben az épület falába építve - tömegesen kerültek elő az Iseumból származó faragványok (6. kép), ez a jelenség a szentély bontása utánra keltezi az épület létesítését. ${ }^{128}$

A horreumtól északra eső terület számos pontján a 4. század derekától fogva szórványosan temetkezések kerültek a felszínre. ${ }^{129} \mathrm{~A}$ rövid ideig - alig néhány évtizedig - múködő temetô sírjainak egy részét még a római időszak végén kihantolták, az emberi maradványokat pedig a kegyelet legkisebb nyoma nélkül a szentély egykori még ebben az időszakban is múködő - kútjába szórták bele. ${ }^{130} \mathrm{~A}$ fenti eseménysor számos kérdést vet fel a terület történetével kapcsolatban. Nyilvánvaló, hogy a környék funkciójának rövid időn belüli többszöri radikális megváltozása nem magyarázható a terület természetes átalakulásával, sokkal inkább az emberi beavatkozás jeleit lehet megfigyelni. A temetkezések felszámolásának okát nem ismerjük, de ezek között a horreum létesítése is felvethető, hiszen sírok jelenléte egy élelmiszerraktár területén vagy annak közvetlen szomszédságában nem lehetett kívánatos.

375 ősze birodalmi jelentőségú események színterévé tette Savariát. ${ }^{131}$ A téli szálláshelyet Savariában kereső és megtaláló Valentinianus és udvara, valamint a velük együtt érkező katonaság elhelyezése mellett ellátásuk biztosítása is különleges helyzet elé állíthatta a város és a tar-

\footnotetext{
127 Erre lásd NAGY [2017], főként a 37. és 38. jegyzet.

128 SOSZTARITS 2010, 150-151; SOSZTARITS 2016, 40.

129 SZENTLÉLEKY 1966; SKRIBA-KISS 2007, 288; SOSZTARITS 2010, 150-151; BALÁzs-CSAPlÁros-SoszTARITS 2013, 45; BíróSOSZTARITS 2013; SOSZTARITS 2016, 40-41; illetve Sosztarits Ottó: Früher eine Stadt, jetzt ein Gräberfeld. - Funktionsänderungen in der Stadt- und Siedlungsstruktur im südlichen Stadtviertel von Savaria. V. International Colloquium on Norico-Pannonian Autonomous Towns. 2011.10. 26. (előadás kézirata).

130 BALÁzs 2012, 75.

131 Amm. Marc. XXX. 5.14-18. Vö. BALla 1963, 75-79.
} 
tomány igazgatását. Nyilván nem csak a palotanegyed átalakítása és a császári udvartartás igényeihez való igazítása jelentett feladatot, ${ }^{132}$ hanem a nagyszámú hivatalnok és a fegyveres kíséret biztonságos élelmiszer-ellátásáról is gondoskodni kellett. Ennek a megnövekedett élelmiszer-mennyiségnek a raktározását feltehetően nem lehetett megoldani a meglévő raktárépületek révén, ami szintén további raktárépületek emelését tehette szükségessé. A tágabb időbeli egybeesésen kívül azonban semmilyen bizonyítékunk nincsen a déli horreum és Valentinianus savariai tartózkodása közötti összefüggés igazolására. Annyi azonban biztos, hogy ezt az épületet ott építették fel, ahol a lebontott korábbi „pogány" templomépületből nagy mennyiségú építóanyag állt rendelkezésre egy nagyszabású építkezéshez. Amennyiben pedig a csapatok itt teleltek volna, a lebontott és elplanírozott terület elégséges helyet biztosított volna az itt telelni szándékozó katonaság számára.

Ha a Savariában eddig ismertté vált, lehetséges horreumként meghatározható épületeket öszszevetjük Pannonia más vagy a birodalom jól kutatott területeiről származó (gabona)raktáraival, néhány fontos megállapítást tehetünk. Általánosnak mondható topográfiai jellegzetesség, hogy a horreumok - néhány kivételtól eltekintve ${ }^{133}-\mathrm{az}$ erődített város területén, tehát a falakon belül kapnak helyet. ${ }^{134}$ Közelebbi elhelyezkedésüket tekintve közvetlen a kapuk belső oldalán, az út mentén hosszában, esetleg egymással szemben az út két oldalán találjuk őket. Máshol meglepő módon a városközpontban, a forum térségében ${ }^{135}$ épültek fel a raktárak, fóként ott, ahol használaton kívüli, lebontott épületek helyére tudták emelni őket.

Savariában jelenleg a városfallal körbevett, belső, jól védhető területről nem ismerünk akárcsak feltételesen is - horreumként meghatározható építményt, mindkét épületünk a falakon kívül, tehát védtelen területen helyezkedik el. A mai kutatás alapján egy további, a külvárosokat is magában foglaló külső védvonal létét nem

132 Legutóbb összefoglalóan TóTH 2011, 278-281; IsZTIN-TÁRCZYТо́тн 2013, 196.

$133 \mathrm{Pl}$. Aquileia, lásd 112. jegyzet.

${ }^{134}$ E. Rizos figyelt fel a jelenségre, hogy több esetben a település városfalának megerősítése, illetve valamilyen módon erődítése, továbbá a horreumok megjelenése mindenképpen a térség/provincia életében betöltött megváltozott funkcióra és megnövekedett feladatokra utal. Rizos 2013, 671-672.

${ }^{135}$ Vö. Scarbantia (92. jegyzet), Nicopolis ad Istrum (120. jegyzet), Tropaeum Traiani (121. jegyzet) példáit. tudjuk igazolni. ${ }^{136}$ A déli sánc keltezése bizonytalan, létesítésekor egyébként is a déli külváros épületeinek zömét már lebontották.

A császári székvárosokéhoz hasonló léptékû, 60-80 méter hosszúságot is meghaladó méretû, több belső pillérsoros raktárépületek savariai létét mai ismereteink alapján nem valószínúsíthetjük. Az Iseumtól délre fekvő granarium méretét tekintve a közepes nagyságú horreumok közé sorolható. Hosszúsága és szélessége mintegy fele, alapterülete nagyjából a negyede a legnagyobb sirmiumi építménynek. Támpillérek nélküli, két pillérsoros szerkezete alapján a raktárépületek legáltalánosabb csoportjába tartozik. Rövidebb, keleti oldalát a Borostyánkő út vonala zárta le, de toldaléképítményre utaló falmaradványok az északi hosszú oldalon sem mutatkoztak. Mivel felmenő szerkezetei nem, csupán alapfalai maradtak meg, ezért bejárata(i) nem ismert(ek). Részleges kutatottsága ellenére szinte teljes biztonsággal kizárhatjuk kettős vagy ikerhorreum jellegét. A hosszanti elrendezésú kettős horreum jellegének lehetőségét a telek nyugati végén húzott átlós kutatóárkunk alapján zárhatjuk ki. Csatlakozó építmény léte a lényegében még nem kutatott déli oldalon sem valószínú.

\section{Összegzés}

Savariában régészetileg igazolható horreumként csak a feliraton szereplő horreumok tekinthetők. A városból ismert - vélhetően raktár funkciójú épületek közül egy erősen feltételes módban („,keleti horreum”), egy pedig nagy biztonsággal tekinthető horreumnak. Feliratban említett létesítményekkel való megfeleltetésük az előbbi esetén bizonytalan, az utóbbi esetén kizárt. A Római Birodalom más igazgatási központjaiból ismert gabonaraktárak - a nagy tömegú élelmiszer könnyebb szállíthatósága miatt - általában a kapuk térségében, a városok főutcája mentén helyezkedtek el, zömében a városfalakon belül. Számos példa van azonban a falakon kívül emelt

136 A korábbi, az 1960-as, 70-es évek topográfiai kutatásai a Kr. u. 2. század folyamán kiterjedt várossal és a várostest egészét körbekerítő városfalakkal számoltak (BUócz 1968, 9-12; KÁROLYI-SZENTLÉLEKY 1967, 26-27; TÓTH 1971, 152-155). Csak a nyugati városfal azonosítását (Buócz 1991, Abb. 3), illetve a déli városfal vonalának meghatározását (SOSZTARITS 1994, Abb. 1) követően vetődött fel egy esetleges külső, a terjeszkedő város védelmét biztosító erődítés lehetősége. Ellenkező tendencia, pl. Scarbantia esete, ahol a késő római időszakban épült városfal egy szúk területet fogott csak körbe. (Vö. Póczy 1967, 137, skk.) 
tárolóépületekre is, emiatt további ilyen épületek bárhol elókerülhetnek Savariában.

A déli horreum és a környékén előkerült gabonaórlés eszközei között nem látunk kapcsolatot, ismereteink szerint csak véletlen topográfiai egybeesésről van szó. A horreum építésének és Valentinianus 375-ös savariai tartózkodásának időbeli közelsége az ok-okozati összefüggés lehetőségét kínálná. A ma még teljesen hipotetikusnak tekinthetó felvetést az általunk ma ismert régészeti érvek csupán lehetôvé teszik, de nem bizonyítják. Így tartományi vagy birodalmi jelentőségú épületnek csak a Vulcacius Rufinus építési feliratában szereplő magtárakat tarthatjuk.

\title{
FÜGGELÉK
}

\section{SAVARIA IV. SZÁZADI TÖRTÉNETÉNEK KÉRDÉSEI*}

\author{
NAgy Tibor (1910-1995)
}

\begin{abstract}
A szerző ezt a tanulmányát 1970-1980 körül írta, és a lábjegyzetelést nem fejezte be. Feltételezhetô, hogy tanulmányának elkészítését Balla Lajosnak 1963-ban az Archaeologiai Értesítőben Savaria invalida címmel megjelent tanulmánya indokolta, bár Nagy Tibor nem hivatkozik Balla cikkére. Ennek oka azonban az lehet, hogy a jegyzetei befejezetlenek maradtak. A tanulmányt változatlan formában közöljük, a nagyrészt kézzel és rövidítésekkel irt jegyzeteket pontositottuk és kiegészitettük. Nagy Tibor tanulmányának jelentőségét az adja, hogy írásának idején még nem volt ismert Savaria 4. századi kétségtelenül gyenge védelmi képessége, sem a később megtalált raktárépületek. Vulcatius Rufinus feliratának elsö, alapos feldolgozását ebben a tanulmányában készítette el, széles körü kitekintéssel a késő császárkori logisztikai problémákra, a Valentinianus-kori pénzforgalom alakulására, Savaria invalida jelzöjének Balla Lajostól eltérö értelmezésére. Szerencsés körülmény, hogy Nagy Tibor dolgozatával együtt jelenik meg a savariai horreumokról készített tanulmány. (Tóth Endre)
\end{abstract}

A római principatus idejében, éspedig a Traianustól Diocletianusig terjedő, közel két évszázadnyi időszakban Felső-Pannonia katonai, polgári, valamint pénzügyi igazgatási és vallási szervezete három városban összpontosult. A senatorok közül kinevezett consularis rangú tartományi helytartó székhelye és egyúttal a tartomány katonai és polgári közigazgatásának központja a Duna menti Carnuntumban volt. ${ }^{1}$ Felső-Pannonia pénzügyi-gazdasági szervezetének vezetője, a centenarius rangú, lovagrendú procurator, aki a tartományi tisztviselők rangsorában közvetlenül a helytartó után következett, a Dráva-parti Poetovióban (Ptuj) székelt. ${ }^{2}$ A procurator székhelyének megfelelően ugyancsak Poetovióban helyezték el a felsőpannoniai tartományra vonatkozó adókimutatások központi nyilvántartó hivatalát, a tabularium provinciae Pannoniae superiorist. ${ }^{3}$ Poetovióban múködött azonkívül a Regensburgtól keletre fekvő dunai tartományokat, valamint Dalmatiát és Venetiát magában foglaló illyri-

* Kézirat: Budapesti Történeti Múzeum Régészeti Adattár H.2652-2013. A szöveget Tóth Endre gondozta.

1 KubitscheK 1899; Reidinger 1956, 21; SwOBOda 1953, 41. (2. kiadásban).

2 SARIa 1951, 1178; PAVAN 1955, 411; Mócsy 1962, 593.

3 Az epigráfiai anyag összeállítása: SARIA 1951. cumi vámkerület (a publicum portorium Illyrici), ${ }^{4}$ valamint a két Pannonia területéről befolyó 5\%-os örökösödési adót (vicesima hereditatum) kezeló hivatal. ${ }^{5}$ A II. és a III. században tehát Poetoviót lehet számon tartani nem csak Felső-Pannonia, hanem egyáltalában a dunai tartományok nagy pénzügy-igazgatási központjaként.

Savaria ezekben az évszázadokban sem a katonai, sem a polgári közigazgatás, sem pedig a pénzügyigazgatás tartományi szervezetében nem kapott jelentôsebb szerepet. Egyedül az illyricumi vámkerületnek volt kirendeltsége (statio) a városban. ${ }^{6}$ Savaria maradt viszont a Traianus nevéhez füződő új tartományi szervezetben is a felső-pannoniai császárkultusz, valamint a császárkultuszhoz kapcsolt tartományi gyúlés (concilium provinciale) középpontja.7 A II. és a III. században, amennyiben háborúk vagy egyéb gátló tényezők ezt nem akadályozták, évenként Savariában gyưltek össze Felső-Pannonia municipium és colonia rangú városainak, valamint a bennszülött kerületeknek a képviselői, hogy az ara Augustorum előtt az élő és a konszekrált császárok üdvéért áldozatokat mutassanak be, majd körmeneteket és ünnepi játékokat tartsanak. Közben a tartományi gyúlés ülésein az egyes városok, bennszülött kerületek képviselói előadhatták kéréseiket, esetleges panaszaikat. ${ }^{8}$ Két évszázadon keresztül tehát az említett három városban: Carnuntumban, Poetovióban és Savariában összpontosult külön-külön Felső-Pannonia katonai, pénzügyi és vallási szervezete.

Gyökeresen megváltozott ez a helyzet a IV. század folyamán Diocletianus, majd I. Constantinusnak az egész római államapparátust átalakító reformjai következtében. Diocletianus idejében nemcsak a fennállott nagyobb tartományok jó részét tördelték fel kisebb területi egysé-

4 De Laet 1949, 1751; SARIa 1951, 1153; PAVAN 1955, 463; Mócsy 1962, 59.

5 CIL III 4065; PAVAN 1955, 464-465; bizonytalan, az AIJ 311 sérült oltárkő feliratának feloldása: h(ereditatium?) tab(ularius) DовÓ 1968, 189, No. 335; RIU I 3, 19.

6 CIL III 4155, 4161, 10876; Dobó 1940, 30, 31, 36; De LAEt 1949, 222; PAVAN 1955, 461; Mócsy 1962.

7 Kornemann 1900, 808; Pavan 1955, 533; Mócsy 1962; CIL III $4170=$ RIU 71

8 NAGY 1975, további irodalommal. 
gekre, ${ }^{9}$ hanem következetesen végrehajtották a helytartók katonai és polgári funkcióinak szétválasztását is, amelyet a III. század 60-as, 70-es éveiben még csak a senatori rendú kormányzók esetében tettek meg. ${ }^{10} \mathrm{Az}$ uralkodó felfogás szerint Felsó-Pannoniát Diocletianus idejében osztották fel két kisebb tartományra, Pannonia Primára és Saviára. Az emellett felhozott egyetlen konkrét érv (Aurelius Ianuarius) dux 303. évi brigetiói oltára volt (CIL 3, 10981RIU III 699), így Mommsen nyomán sokáig $\mathrm{P}$ (annoniae) S(ecundae) S(aviae) tartománynevekre oldották fel a $\mathrm{p}($ ro $) \mathrm{s}($ alute $) \mathrm{s}(\mathrm{sua})$ formulát, amelyre már Alföldi rámutatott. A későbbi Savia, valamint Pannonia prima szervezése is csak I. Constantinus idejében történt meg, ${ }^{11}$ de a tetrarchia kormányzata a Pannonia superior néven meghagyott osztatlan tartományban sem mulasztotta el a helytartók polgári és katonai funkcióinak szétválasztását. A Duna menti táborokban állomásozó katonaság parancsnoka a dux lett, akinek székhelye továbbra is Carnuntumban maradt. ${ }^{12} \mathrm{Az}$ igazságszolgáltatás, egyáltalában a polgári adminisztráció vezetését azonban külön polgári kormányzóra (praeses, iudex) bízták, aki igazolhatóan már 303-ban Savariában székelt. ${ }^{13}$

Miután pedig Diocletianustól kezdődően az újonnan bevezetett terményadó, az annona kivetését és behajtását is a polgári kormányzó hatáskörébe utalták, ${ }^{14}$ az utóbbi örökölte a korábbi procuratori hatáskör egy részét is. Ily módon az adólisták vezetése, melyet korábban a poetoviói procuratori hivatalban végeztek, a IV. században már a Savariában székelő polgári kormányzó hivatalának feladatköréhez tartozott. A helytartó officiumában egy külön osztály (schola), amelynek élén az egyik tabularius állott, látta el a terményadó kivetésével és behajtásával együtt járó teendőket is. ${ }^{15}$ Ebből a háttérből érthető, hogy a polgári kormányzó felettese, az illyricumi praefectus praetorio a 340-es évek végén gabonaraktárakat (horrea) építtetett Savariában. Erről még részletesebben lesz szó. Aterményadózás mellettazután legkésőbbI. Constantinus uralkodásától kezdve a két Dráván inneni pannon tartomány, valamint a két Noricum pénzügyigazgatásának központját is Savariába helyezték. E városban székelt a praepositus thesaurorum, aki az említett négy tartományra

9 Lactantius, de morte persecutorum 7,4: provinciae quoque in frusta concisae... Mommsen, Ges. Schriften fejtegetései után sokáig a Laterculus Veronensis néven ismert provincia jegyzékében (SEECK 1876) láttuk a Diocletianus-kori tartományok felsorolását. Ma már világos, hogy a jegyzékben még I. Constantinus korában is módosítottak. Részletesen szólunk erról a „Tres Pannoniae” c. tanulmányunkban [nem jelent meg].

10 Lásd erre megjegyzéseinket, NAGy 1964.

11 Vö. „Tres Pannoniae” c. tanulmánnyal [nem jelent meg].

12 Erre közvetlen adat nincs.

13 Passio Quirini. A vértanúság keltezésére NAGY 1939. Érvelésünket nem ismerve legutóbb J. Moreau különben kitúnó munkájában (MOREAU 1961) 305 utánra keltezte Quirinus vértanúságát. Az Iraeneus- és a Quirinus-passiók elbeszéléséből azonban egyaránt kitûnik, hogy a laikus keresztények akkor még szabadon mozogtak; a 4. edictum tehát még nem jelent meg.

14 [hiányzó hivatkozás]

15 Nesselhauf 1938. nemesfémben (aranyban és ezüstben) kivetett adók nyilvántartását és kezelését intézte. ${ }^{16}$

A principatus évszázadaival szemben a IV. században tehát - a katonai parancsnokságtól eltekintve - valamenynyi fontosabb tartományi közigazgatási szerv központi irodái Savariába kerültek. Valószínú, hogy a Pannonia prima területén fekvő uradalmi erdőségek (silvae dominicae) igazgatása is innen történt. ${ }^{17}$ A IV. századi Savaria ily módon ténylegesen is tartományi fővárosnak tekinthető, hiszen itt nemcsak a polgári helytartó székelt, hanem ugyancsak innen irányították Pannonia prima pénzügyi és gazdasági ügyeit is. Bár nincs rá konkrét adatunk, jogosan feltehető, hogy még a IV. században is politikai súllyal rendelkező császárkultusz és tartományi gyúlés székhelyét sem vitték el innen máshova. ${ }^{18} \mathrm{~A}$ tartományi közigazgatást irányító hivatalok ilyen nagymérvú koncentrálása Savariában kétségtelenül hozzájárult ahhoz, hogy a város területén a IV. század első felében viszonylag élénk építési tevékenység bontakozott ki. Ugyanis az idekerült tartományi helytartó és az idővel mind nagyobb létszámú hivatala részére komoly, palotaszerú épületről kellett gondoskodni. Hogy ez a IV. századi helytartói palota területileg milyen összefüggésben állott az Ammianus egyik adatából ismert császári palotával, ${ }^{19}$ arra remélhetően a folyamatban lévő ásatások derítenek majd fényt, de ugyanakkor el kellett helyezni a pénzügyigazgatási szerveket. A praepositus thesaurorum, valamint hivatala a tartományi kincstárral együtt szintén valami nagyobb épületet igényelt. A terményadózás megszervezése épületekben is új feladatok elé állította a várost. Savariát a tartomány területéról beszolgáltatott terményadó tárolásának egyik központjává jelölték ki. ${ }^{20}$ Ezért nem csodálható, hogy már a század negyvenes éveiben újabb gabonaraktárakat kellett építeni, amint erről egy épületfelirat tudósít.

A régészeti és a történeti adatok azonban nemcsak az állami építkezésekre nyújtanak példákat. Építkezett a városban a keresztény egyházközség. A soproni kapu, a porta Scarabatensis közelében emelt Quirinus-basilica ${ }^{21}$ - a Pannonia területéről ismert többi keresztény kultuszépülethez hasonlóan - ugyanis majdnem bizonyosan nem állami költségen, hanem az itteni egyházközség tagjainak anyagi hozzájárulásaiból épült fel. A IV. századi Savariában azonkívül jogosan számolhatunk még a katonaság építkezéseivel is, minthogy legkésőbb I. Constantinus uralkodásától kezdve a savariai lándzsások (lancearii Savarianses) nevú helyőrség állomásozott a város területén. ${ }^{22}$ Már a föntebbi példák ismeretében is túlzás nélkül állítható, hogy Sirmiumtól, a pannoniai városok anyjától (mater urbium - mint Ammianus nevezi) ${ }^{23}$ eltekintve a IV. században talán egyetlen más pannoniai városban sincs tudomásunk olyan sokirányú építkező tevékenységről, mint Savariában.

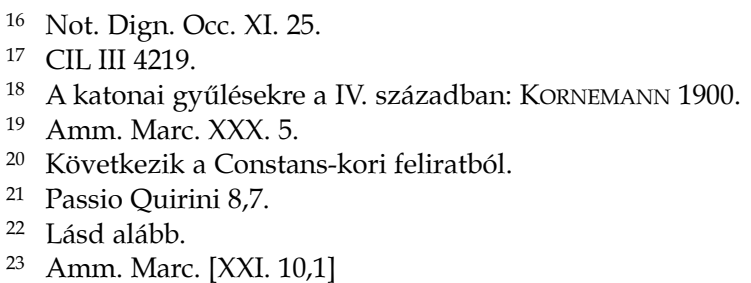


A korábbi századok városképét nem egy helyen lényegesen modifikáló építkezések jelentős részükben elválaszthatatlanok attól a ténytől, hogy a IV. században Savaria Pannonia prima tartományigazgatásának központja. A Drávától északra fekvő területekről - a katonai támaszpontok szerepét játszó újsütetú belső-pannoniai erődített telepektől ${ }^{24}$ eltekintve - egyedül Sopianae (Pécs) IV. századi felfejlődése, urbanizmusa állítható Savariáéval párhuzamba. ${ }^{25}$ Ezért nem lehet véletlen, hogy mindkét várost a Diocletianus-féle tetrarchia idejében tartományi székvárossá jelölték ki. Egyiknél sem vonható kétségbe, hogy IV. századi városfejlődésük, amelynek mértéke pl. a limes menti telepek stagnálásával, ső́t elsorvadásával szembeállítva különösen szembeszökő, nemcsak védettebb földrajzi fekvésüknek, a közlekedési csomópontokból adódó helyzeti energiájuknak köszönhető, hanem összefüggésben állott a falaik között múködő különféle központi jellegú hivatalok jelenlétével is.

A savariai építkezéseknek és egyúttal a IV. századi várostörténetnek értékes emléke a gabonaraktárakra vonatkozó, már többször említett felirat, amely a Beloiannisz (jelenleg Kőszegi) utcában került napvilágra. ${ }^{26}$ A kor stílusának megfelelően kissé fellengzős és szerkezeti felépítésében is eléggé körülményes felirat szövege a következőképp hangzik: „A mi urunk, a mindenkor gyöztes és gyo”zedelmes Constans császár boldogságáért. Gondoskodva arról, hogy a magtárakban mutatkozó hiányt böség váltsa fel, miután a gabonatároláshoz szükséges raktárakban hiányok kezdtek mutatkozni, Vulcatius Rufinus, az igen kitünö férfiú (vir clarissimus), praefectus praetorio, az építkezést saját hatáskörében megkezdte, a raktárakat a terményadózás örök biztositására felavatta" (horrea in securitatem perpetuam - a kövön perpetem áll - rei annonariae dedicavit).

Az építési feliratot Vulcatius Rufinus, kora egyik legbefolyásosabb férfija állíttatta. Vulcatius Rufinus közeli rokonságban állott a Constantinus-féle dinasztia tagjaival. ${ }^{27}$ Gallus Caesarnak és a későbbi Iulianus Caesarnak nagybátyja volt. 346 és 350 között rokona, Constans császár birodalomrészében Illyricum prafectura legfőbb polgári vezetője (praefectus praetorio per Illyricum). ${ }^{28}$ 350-ben, amikor Magnentius Galliában magához ragadta a hatalmat, Vulcatius Rufinus II. Constantius nővérével, Constantiával együtt egyik kezdeményezője volt annak az akciónak, amely a Constantinus-féle dinasztia érdekeit szem előtt tartva Illyricum katonai parancsnokát (magister

24 RADNÓTI 1954. Katonai jelentóségükre NAGY 1954.

25 NAGY 1943. Kétségbe vonja a jelenségek összefüggését Fülep: NAGY 1987-1988.

26 CIL III 4180. ILS 727, RIU 48.

Beatitudine $\bullet d($ omini) $\bullet n($ ostri) $\bullet$ Constantis victoris / ac triumfatoris semper $\bullet$ ug (usti) / provisa copia quae horreis deerat / postea quam condendishorreadeessecoeperunt/haec Vulc(acius)・Rufinus •v(ir)・ c(larissimus)•praef(ectus)•praet(orio)•per se coepta/in securitatem perpetem rei annonariae dedicavit.

27 Teljes cursus honorumát ILS 1257. SЕECK 1914, 1187; 1906, 212; PALANQue 1933, 25.

28 Codex Theodosianus XI. 1,6 (a császár ebben Rufinust operens amicusqae noster-nek nevezi. E rendelet szerint 346-ban Italia pref. praetoriója (tehát akkor Illyricumé és Africáe is?); említett régebbi rendelete 346-ban kelt (CHASTAGNOL 1960, 322). A Codex Justinianus VI. 62,3 mutatja, hogy 349. december 28-án Rufinus hivatalban volt. ENSSLIN 1954, 2432, 26. peditum per Illyricum), Vetraniót emelte trónra. ${ }^{29}$ A praefectus praetorio ekkor Sirmiumban tartózkodott testvérével, Neratius Cerialisszal. Ez utóbbi azzal írta be nevét a pannoniai egyháztörténetbe, hogy tagja volt annak a vizsgálóbizottságnak, amely Photinost, Sirmium püspökét, az ankyrai Markellos tanítványát, eretneknek bélyegezte, és Kis-Ázsiába számúzte. ${ }^{30}$ A IV. század negyvenes éveinek végén tehát ennek a császári házzal közeli rokonságban álló Vulcatius Rufinusnak a kezében futottak össze Illyricum és ezen belül Pannonia prima kormányzásának ügyei. A császár után ő volt a Savariában székelő helytartó legmagasabb hivatali felettese.

I. Constantinus uralkodása óta e regionális praefectusok hatáskörébe tartozott a katonaság és az állami tisztviselők ellátmányát biztosító terményadók (annona) kivetésének, behajtásának és szétosztásának legfőbb irányítása. ${ }^{31}$ A gyakorlatban a regionális praefectusoknak szabad keze volt a katonaság gabonaellátását biztosító intézkedések (mint kényszerfuvar, raktározás stb.) megtételére is. ${ }^{32}$ Ezzel a hatalmával élt Vulcatius Rufinus, amikor Savariában új raktárakat építtetett. ${ }^{33} \mathrm{~A}$ felirat a res annonariá-t emlegeti, tehát kétségtelen, hogy az új raktárak a katonaság ellátásával függtek össze. Ez utóbbiról röviden annyit, hogy a IV. század első felében a határsávban állomásozó (ripenses), valamint a mozgó seregrészekhez (comitatenses) tartozó alakulatok a donativumon kívül még egyaránt természetben kapták meg egész javadalmazásukat. ${ }^{34} \mathrm{Az}$ egyes csapatparancsnokok részéről azonban már I. Constantinus idejében felmerült az a törekvés, hogy nem veszik át a csapattestekre kivetett naturáliákat, hanem ehelyett magas megváltási árat követeljenek az annona nyilvántartását végző praesidialis szervektól (procuratores seu susceptores), illetve a falvak vagy az élelmiszerraktárak vezetóitól (praepositi [...] et horreorum. $)^{35} \mathrm{Az}$ új módon kikényszerített magas ár és az egyszerü katonáknak kifizetett hivatalos ár közötti különbözetet (interpretium) saját céljaikra fordították. A szükséges adaerálás ennek ellenére megmaradt, amint II. Constantius egyik rendeletéból látjuk. ${ }^{36}$

29 Rufinus szerepe következik a Petros Patrikios frg.16 (FHG IV 190) által elbeszélt követségből: CHASTAGNOL 1960, 421. Constantia szerepére: Philostorgios III 22; SEECK 1897, IV, 98; Stein-Palanque 1959, I 125; Vetranio külsejére Aurelius Victor Caesar 41, 27; ENSSLIN 1930, 321, 24; 1931, 104. 350-ben Rufinus Illyricum polgári fókormányzója, míg Vetranio katonai föparancsnoka volt.

30 Epiphanius, Panarion LXXI 1,8 (Holl 1915, 250); NAGY 1939, 127 skk.

31 Stein-Palandue 1959, 177, 180; EnsSlin 1954, 2428; jellemző: Amm. Marc. XVI. 3,4; XVIII. 2,4 (Florentinus Julianus mellett).

32 Vö. Aurelius Victor Caesar XIII. 6; Amm. Marc. XIX. 11,2.

33 CIL III 4180; ILS 727.

34 SEECK 1897, IV 257. II. Constantius 358. évi rendelete (Codex Theodosianus VIII. 4,6) már régi szokásként (ex more) jelöli a katonaság teljes évi ellátmányának természetbeni átvételét (susceptis omnibus alimoniis militaribus). A stipendium jelentésváltozására (=donativum) Diocletianus után 545/27 SEECK 1914.

35 Codex Theodosianus VII. 4,1. MAZZARINO 1951, 164, bő kommentárral.

36 Lásd fentebb a 34. jegyzetben idézett rendeletet. 
A kérdés elsősorban a határ menti csapatokat érintette. A comitatenses mögé sorolva ezek bizonyára csak a mozgó alakulatok szükségleteinek kielégítése után kapták meg fejadagjukat, ami gyengébb minőségú volt. Ugyanakkor szállítási problémák is többször késleltették az ellátmányt. Valentinianus és Valens ezen a problémán úgy segített, hogy megengedték 3 hónapnak megfeleló ellátmány adaerálását. ${ }^{37}$ Ugyanakkor, hogy az interpretiumból adódó nyerészkedésnek elejét vegyék, illetve korlátok közé szorítsák, megállapították a megváltási árat. 364/5-ben a szállítási nehézségek ezt úgy módosították, hogy a limes-sávban állomásozó katonaságnak az adaeratio alkalmazásával pénzben fizették ki a természetbeni ellátmányuknak megfelelő összeget. Pár évvel később ${ }^{38}$ I. Valentinianus még tovább ment, és az illyricumi városokban állomásozó comitatenses alakulatokra is kiterjesztette, hogy pénzben kapják meg az előírt fejadag meghatározott ellenértékét. ${ }^{39}$

A katonai ellátmány 25\%-ának adaerálása adja meg a magyarázatát annak, hogy I. Valentinianus uralkodásának éveiben Pannoniában miért szökik fel olyan hirtelen a pénzforgalom volumene. ${ }^{40} \mathrm{Ez}$ a gabonaszolgáltatás valójában az élelem adaerálásának következménye. Constans idejében az annona adaerálása azonban még korántsem öltött ilyen méreteket. A határ menti és a tartomány belsejében állomásozó alakulatok akkor még egyaránt természetben kapták meg illetményüket.

Nem volt azonban mindig könnyú olyan központi fekvésú gyưjtő- és elosztóhelyeket kijelölni, ahonnan a terményadóként beszolgáltatott gabonát a katonaság között aránylag gyorsan szétoszthatták. Savaria ebból a szempontból viszont ideális fekvésúnek számított. Elég csak utalnunk a város kitúnő közlekedés-földrajzi helyzetére, amely a Vindobona, Carnuntum és Brigetio felé kiágazó útvonalai révén a limes-sávnak, a SavariaAquincum útvonal segítségével pedig a mozgó seregrészek belső-pannoniai állomáshelyeinek - mint pl. Cimbrianis, ahonnan egy pseudo comitatensis legiót ismerünk - gyors megközelítését biztosította. ${ }^{41}$

Az egyes katonai alakulatok gazdasági tisztjei, akik az annona militaris átvételéről, valamint szállításáról gondoskodtak, tehát mind a limes-sávból, mind pedig a belső erődített telepekről - ilyenek már a II. Constantius előtti időkben is léteztek - könnyen megközelíthették Savariát, és aránylag gyorsan lebonyolíthatták a csapattestüket illető annona átvételét és elszállítását. E központilag szervezett gabonaelosztás zökkenőmentes funkcionálását azonban egy ideig akadályozta, hogy hiányoztak a megfelelő befogadóképességú magtárak Savaria területén. Ezt a hiányosságot kívánta Vulcatius Rufinus felszá-

37 VÁRADY 1961, 88.

38 Codex Theodosianus VII. 4,17, Valens rendelete 365-ből, de hogy ennek megfelelő tartalmú rendelkezést Valentinianus is kibocsátott a nyugati birodalomrészre, következtethetó Valentinianus [...] évi rendeletéből, amely a mozgó seregrészeket érintette. [A kéziratból a rendelet kiadásának éve hiányzik.]

39 Codex Theodosianus VII. 4

40 Carnuntum [hiányzó hivatkozás]; Aquincum: PEKÁRY 1953.

41 [Itinerarium Antonini Augusti 267,8; Not. Dign. Or. 40, 27]. molni, amikor a városban újabb magtárak építését rendelte el. Az építkezés jelentőségére rávilágíthat többek között az a tény is, hogy a magtárakat a praefectus praetorio személyesen avatta fel (haec sc. horrea Vulcatius Rufinus dedicavit). ${ }^{42}$ Nem tudjuk, hogy Rufinus honnan teremtette elő az építkezésekhez szükséges pénzügyi fedezetet. A feliraton a provisa copia hangsúlyozása inkább arra mutat, hogy a praefectus az évenként összeállított költségvetési összeg keretében gondoskodott az építkezés költségeinek előteremtéséről. Annyi kétségtelen, hogy a magtárak nem a császári fiscus anyagi hozzájárulásából épültek, különben a felirat nem mulasztaná el ezt valamilyen formában kifejezni (pecunia sua, fisci sui suptu, sua largitate etc.). A 15 éves ciklussal (indictio) dolgozó késő római állami költségvetés ismeretében lehetséges bár kevés a valószínúsége -, hogy a 342-ben történt adóösszeírás, illetve költségvetési összeg kijelölése alkalmával számoltak volna a res frumentaria vonalán 4-5 év múlva jelentkező raktározási problémákkal. Sokkal inkább valószínú, hogy Rufinus is a pótadó (superindictio) eszközéhez nyúlhatott.

Mindenesetre az írott források arra utalnak, hogy e superindictiones Constans idejében még nem váltak a praefectusok kezében olyan gátlástalan pénzszerző eszközzé, mint II. Constantius és főként I. Valentinianus uralkodása idejében. Tragikus ellentmondás, hogy a főként a kisembereket sújtó pótadók kivetése az illyricumi praefecturában éppen annak az I. Valentinianusnak az uralkodási éveiben harapózott el, aki pedig a defensor plebis tisztség felállításával és törvényerejú rendeleteinek egész sorával hatékonyan kívánta megvédeni az innocens et quieta rusticitas, azaz a kis adófizetők, a collatores érdekeit. De Illyricum területén ennek az anomáliának is megtalálható a magyarázata. Amikor ugyanis a 360-as évek végén a császár elrendelte a Duna menti limes újjáépítését, akkor még a 357. évi adófelmérésen alapuló, 15 éves költségvetési ciklus volt érvényben. Ezzel szemben 357-ben reálisan számolhattak a küszöbön álló szarmata háborúk költségeivel. Erre a célra valóban nem is volt szükség különadó kivetésére. Ezért írhatta Ammianus $(19,11,29)$ elismeróen az állami szervezetek tevékenységéről: „Anatolius, aki abban az időben mint praef. praetorio Illyricumot kormányozta, már jó előre összegyújtött mindent a hadjárat szükségletére úgy, hogy bóvében volt minden anélkül, hogy bárkit is zaklatni kellett volna" (értsd különféle pótadókkal). Általánosan elismert, folytatja Ammianus, hogy egészen a mai napig (azaz a IV. század végéig) soha más praefectus intézkedései nem juttatták az északi tartományokat olyan virágzó helyzetbe, mint Anatoliusé. Anatolius Valentinianus-kori utóda az illyricumi praefecturában, Petronius Probus azonban egészen 372-ig még azzal az indikciós kerettel kényszerült számolni, amelyet 357-ben állítottak össze, s amelyben természetesen nem szerepeltek a 360-as évek

42 Ellenkező esetben ezt átruházta volna a vicariusra vagy még inkább a helytartóra, mint ahogy Valentinianus és Valens a Róma városi pons Valentinianus felavatását. 
végén napirendre tűzött limes-építkezések költségei. Hiába bocsátotta I. Valentinianus a limes-építkezések költségeinek fedezésére az uradalmi birtokok jövedelmének 2/3-át, a 10 évvel korábban összeállított indikciós keretból még így sem futotta a kiadásokra. Petronius Probus nem tehetett mást, mint hogy a különadók egész sorát vetette ki Illyricum lakosságára, csak hogy a szigoráról ismert uralkodó rendelkezéseinek eleget tehessen. Ezzel viszont kiérdemelte Ammianus szigorú ítéletét, amelyet a különben is sötét színekkel dolgozó történetíró híres Probus-jellemrajzában olvashatunk $(30,5,5)$ : „Probus szem előtt tartva a császárnak azt a törekvését, hogy minden lehetséges módon pénzhez jusson... átkos új adónemeket (exitialia provisorum nomina titulorum) talált $\mathrm{ki}$, amelyek egyaránt tönkretették úgy a nagy, mint a már megviselt kis vagyonú embereket. A közszolgáltatások és az adók állandó folytonos emelése több módos embert (optimates) a teljes tönkremenésük előtt elvándorlásra kényszerített. Másoktól a folyton követelőző adóvégrehajtók embertelensége kisajtolta mindenüket, s mivel nem volt miból adniuk, az adósok börtöneinek állandó lakói lettek."

Az eseményekkel egykorú Ammianus idézett szavaiból hitelt érdemlőnek tartható, hogy ez a kíméletlen adópolitika egész Illyricum, tehát ezen belül Pannonia prima adóköteles lakosságának legkülönbözőbb rétegeit egyaránt sújtotta. Amikor tehát Ammianus a 375. évi császárlátogatás alkalmával Savariát „a sưrưn ismétlődő csapásoktól sújtott" városként jellemzi (Savaria ... malis adsiduis adflicta), akkor igazat adhatunk azoknak a kutatóknak, akik a bajok (mala) sorában első helyen a 370-es évek szerencsétlen adópolitikájának kihatásaira gondolnak.

Ammianus ugyanakkor az „erôtlen”, "legyengült” jelzővel is illeti Savariát (Savaria eo tempore invalida). E megállapítása azonban nem függ össze az előbb említett bajokkal és csapásokkal. Mondattanilag a quae kötőszóval összekapcsolt két mellérendelt mondattal állunk szemben, amelyek közül a második, ahol a csapásoktól vert Savariáról történik említés, és Ammianus szövegében nem áll ok-okozati összefüggésben az előző mondat "gyenge", „erőtlen" Savaria tételével. A Savaria invalida említésével Ammianus nem a gazdasági bajokra kívánt utalni, hanem írói gyakorlatának megfelelően a várost ez alkalommal is a védmúvei és lakosságszáma alapján értékelte. Az idézhető számos példa közül most csak egyet említenék, Az „invalida” jelző fontosabb jelentését az alábbi néhány példa világíthatja meg Ammianus szóhasználatában: a perzsa háborúk idején, 359-ben a rómaiak kiürítették a mezopotámiai Carrhae városát, minthogy ezt gyenge fal vette körül, írja munkája egyik helyén Ammianus (18,7,3): ... deseri Carras, oppidum invalidis circumdatum muris. Ezzel szemben a Firmus elleni háborúban az africai Gaionas nevú telepet, ami a lázadó maurik egyik legbiztonságosabb mentsvára volt (receptaculum Maurorum tutissimum), igen erős fal vette körül (muro circumdato valida), $(29,5,25)$. Egy másik példa: a lázadó isairiaiak 353-ben hiába próbálták három napon keresztül ostrommal bevenni a pamphyliai Palea nevú helységet, amelyet erős fal védett (valido muro firmatum) $(14,2,13)$.
Valamely települést körülvevő védőfal tehát validus vagy invalidus attól függően, hogy e falak - ellenséges támadás esetén - elég védelmet nyújtanak-e a védónek vagy sem. A murus invalidus ebben az összefüggésben éppúgy jelenthet gyenge építésú, mint elhanyagolt erőd-, illetve városfalat. A föntebbi jelzőpár egyikét azonban nemcsak erőd- vagy városfalra, hanem magára a fallal körülvett telepre is nemegyszer használja Ammianus. A Savaria invalida mellett az egyik legtanulságosabb példa erre nézve a következő. A Tripolis tartománnyal szomszédos austuriani nép harcosai, akik még Iovianus uralkodása évében a tartományra törtek, nem merték Laptis Magnát megtámadni, „minthogy ezt népes és jól erődített városnak tartották", Austuriani ... veriti prope Leptim accedere, civitatem muris et populo validam $(28,6,4)$. A Leptis valida ellentéte a Savaria invalida, és ez utóbbi Ammianus szóhasználatában nem jelent mást, mint hogy a város védmúvei, falai gyengék, illetve elhanyagoltak, a város lakossága pedig csekély számú volt.

$\mathrm{Az}$ „invalida” jelző tartalmát meghatározó első tényezővel, a városfallal kapcsolatban az Ammianus munkájának egy másik helyén olvasható leírásból jól ismert, hogy Savaria városfala 375-ben valóban milyen düledező állapotban volt. A scarbantiai kapu környéke: locus neglectus, ahonnan a felgyülemlett épülettörmeléket csak I. Valentinianus ott-tartózkodása idején kezdték eltakarítani. De megjegyezhetjük, hogy nem néztek ki jobban a kisebb italiai városok sem. Bologna, Modena, Reggio Emilia, Brescia Ambrosius egyik levelében $(\mathrm{I}, 39,2)$ mint omladozó, halott városok (semirutarum urbium cadavera) szerepelnek.

Az „invalida” jelzőt meghatározó második tényezőre, a város népességére, lakosságszámára vonatkozóan még nem rendelkezünk közelebbi megbízható adatokkal. Ammianus utalásából mindenesetre jogosan következtethetünk arra, hogy a város elnéptelenedése a IV. század 70-es éveiben már komolyabb méreteket öltött. Nem a nagy metropolisok (Róma, Carthago, Alexandria, Antiochia, Constantinopolis, Mediolanum, Treviri), hanem a kisebb városok elnéptelenedése a IV. század második felétől kezdődően az antik világ helyesen felismert jelensége. Ebben a gazdasági tényezők közrejátszása, a humiliores és a honorati, a possessores, a curiales életét egyaránt elviselhetetlenné tevő adóterhek szerepe sem vitatott. De hogy konkrétan Savaria példájában a meglévő gazdasági nehézségek és még sok egyéb más lehetséges összetevő milyen mértékben hatottak az elnéptelenedés irányába, azt közelebbi adatok hiányában egyelőre nem tudjuk megmondani.

A Savariát sújtó bajok sorában régóta számon tartja a kutatás a 374. évi kvád-szarmata támadást is. Kétségtelen, hogy omladozó falaival, megritkult lakosságával ez a Savaria invalida a szarmata és a kvád portyák könnyú prédájának ígérkezett - amennyiben ezek Pannonia prima területét is elözönlötték. De éppen erre vonatkozóan sem az írott forrásokban, sem pedig a régészeti emlékanyagban nem találunk semmi biztos utalást.

Ammianus a 374. évi Duna-völgyi események előadásában megáll a Valeria területén lejátszódott hadmúveletek felvázolásánál, és a két comitatensis legio szétverésé- 
nek említése után hirtelen átugrik az ifjú Theodosius Moesia prima területén vívott sikeres harcainak elbeszélésére. Ammianus munkájában e helyen törés mutatkozik. Ez a törés összefügg az író panegyrista tendenciájával. Ammianus ezeket a részeket I. Theodosius uralkodása utolsó éveiben írta, s érthető, hogy gondosan vigyázott arra, nehogy az uralkodónak még mint Moesia ifjú parancsnokának szarmataverő tetteit elhomályosítsa más katonai vezető számottevő sikereivel. Pedig nyilvánvaló, hogy ezt nem kerülhette volna el, amennyiben elbeszéli a kvádok és a szarmaták pannoniai harcainak további alakulását, amelynek második fázisában a belső-pannoniai erődökre támaszkodó Equitius illyricumi főparancsnok már kétségtelenül sikerrel védekezett.

Következtethetünk erre többek között abból is, hogy Equitius a következő, 375. évre is megtartotta a konzulságot, és egyúttal mint Illyricum magister militumja a Duna-völgyi kérdésekben továbbra is I. Valentinianus katonai főtanácsadója maradt. Equitiust az uralkodó környezetében találjuk a 375. évi kvádok elleni háborúban, és az uralkodó ugyancsak Equitius rábeszélésére engedte színe elé Brigetióban a kvád követeket. Mindez nehezen érthető, amennyiben Equitius a korábbi esztendő kvád-szarmata harcaiban olyan siralmasan szerepelt, mint ahogy Ammianus beállítja. A világos és sötét színekkel dolgozó történetírónak azonban szüksége volt Equitius haditetteinek elmellőzésére, hogy az ifjú Theodosiust annál könnyebben avathassa az akkori szarmata harcok hősévé. Egyelőre ennyit Ammianus előadásához.

Ammianuséval azonos tendenciát árul el Zosimos rövidre fogott elbeszélése, melyet Zosimos a forrásként használt sardesi Eunapios munkájából merített. Eunapios viszont ugyancsak még a Theodosius-féle uralkodóház idejében, 410 körül tette közzé történeti munkáját, amelyben a dinasztia alapítójának, I. Theodosiusnak haditettei érthetően kiemelve szerepeltek. Egy másik író, Ambrosius milánói püspök Satyrus nevú testvére halálakor tartott gyászbeszédében arról emlékezik meg, hogy a barbárok az idő tájt oly közelről fenyegették Felső-Italiát, hogy szükséges volt az Alpok átjáróit sebtében emelt torlaszokkal elzárni. Vitatható módon ezt az auktorhelyet a 374. évi kvád-szarmata betöréssel hozták kapcsolatba. Ilyen interpretáció esetében valójában Pannonia prima területe sem maradhatott érintetlenül az Alpokig kalandozó kvád-szarmata portyáktól.

Ambrosius idézett gyászbeszéde azonban a 378. év végén hangzott el, abban az időpontban, amikor a hadrianupolisi katasztrofális vereség utáni keleti gót-alán és hun portyák a Dráva és a Száva völgyében előrenyomulva valóban elkalandoztak Italia határáig. Ezekre vonatkozik Ambrosius utalása is, nem pedig a négy évvel korábban történt és 378-ban már feledésbe ment kvádszarmata betörésre.

A jelen összefüggésben röviden szólnunk kell a Szombathelytól DNY-ra, a burgenlandi Jabing területén talált nagyobb éremleletről. A publikáló a közel másfél ezer darabból álló éremlelet elrejtését a 374. évre határozta meg, és a szarmaták meg a kvádok az évi pannoniai betörésével hozta kapcsolatba. A jabingi lelet alapján a ké- sőbbi irodalom is igazoltnak vette, hogy 374-ben Savaria környékét feldúlták a kvád és szarmata csapatok. Valóban igaz, hogy a jabingi lelet legkésőbbinek meghatározott darabja 374-ben került ki a sisciai verdéből, továbbá hogy a meghatározott érmek sorából hiányoznak azok az S-pontos emissiók, amelyek a későbbi öcsödi és veszprémi éremleletekben megtalálhatók. Vitán felüli tehát, hogy a jabingi kincslelet nem kerülhetett 374 előtt a föld alá. Azonban az éremlelet $12 \%$-át nem tudták meghatározni. Ezért a nagy számok törvénye alapján sem tekinthető megnyugtatóan tisztázottnak, hogy a meg nem határozott $257 \mathrm{db}$ apró rézpénz (centenionalis) között nem lappanganak-e esetleg olyan darabok, amelyek csak 375-ben vagy 376-ban kerültek ki a verdéból. Módszertani szempontból tehát az lehet az egyetlen helyes álláspont, hogy csak a minden darabjában, egész volumenében meghatározott éremleletból vonunk le a politikai történetre vonatkozó időrendi következtetést. A legtöbb II-III. századi éremlelettel kapcsolatban ilyen szempontból nem is emelhető kifogás. Más a helyzet a IV. század második felével záródó éremleletekkel, amelyekben ezek az igen apró és nemegyszer nehezen vagy egyáltalában meg sem határozható kis rézpénzek dominálnak. Az olyan éremleletek, mint amilyen a jabingi vagy az ugyancsak 374-re keltezett, de hiányos wien-krottenbachi alkalmasak lehetnek a gazdaságtörténeti, pénzforgalmi, verdetörténeti stb. kérdések megvitatására, de perdöntő adatként nem használhatók fel a politika és hadtörténet időrendi kérdéseinek vizsgálatánál. A mondottak alapján tehát az a véleményünk, hogy a jabingi éremlelet nem igazolja, miszerint Savaria környékét 374-ben szarmaták és kvádok pusztították.

Ennek a kérdésnek a vizsgálatánál felfigyelhetünk még a következőkre. A kvád és szarmata portyáktól valóban veszélyeztetett Sirmium védmúvei 374 nyarán éppen olyan elhanyagolt állapotban voltak, mint még egy évvel később Savariáéi. Amint Ammianus írja, a falak omladoztak, és a város védóárkát egészen betemette a törmelék. A szarmaták és a kvádok fenyegető közelségére azonban Probus praefectus felocsúdva első ijedségéből sebtében készültségbe helyezte a város védmúveit. Kitisztíttatta az árokrendszert, kijavíttatta, sőt egészen a tornyok magasságáig felhúzatta a városfalat. Probus lázas épító tevékenységével szemben egészen értelmetlenül hat, hogy a Savariában székelő helytartó viszont a kisujját sem mozdította az állítólag veszélyeztetett város védelmében. A falakat 374-ben nem javíttatta ki, nem erósíttette meg. $\mathrm{Az}$ erődített városok Achilles-sarkának számító kapuk közül a scarbantiai még 375 végén is a régi, elhanyagolt állapotban volt, és a többi városkapu környéke sem nézhetett ki jobban.

Mindez nehezen egyeztethető össze azzal, hogy a város környékét ellenséges portyák lepték el, melyek dúlták a város határát. Érthetővé válik viszont Savaria védmúveinek ez az elhanyagolt volta egy évvel a kvádszarmata támadás után, amennyiben a 374. évi betörés lényegében nem jutott túl a belső-pannoniai erődített telepek sávján, és így nem is fenyegette Pannonia prima fóvárosát. $\mathrm{S}$ a jelek valóban arra mutatnak, hogy a tartomány keleti határa közelében húzódó erődített telepek ez 
alkalommal is sikeresen fogták fel a DK felől Pannoniára tört kvádok és szarmaták támadását. Savaria későbbi, IV. század végi, V. századi története részleteiben még homályos. Annyit tudunk, hogy 406 körül a Radagaisus vezette nagy népmegmozdulás elől Savaria keresztényeinek egy része Quirinus reliquiáival együtt Italiába menekült. Már jóval korábban kivonták a városból a savariai lándzsások csapatát, amelyet a 400-as évek elején Galliában találunk az ottani mozgó sereghez osztva.

433-ban Savariára és környékére a hunok tették rá a kezüket. A 455. évi nagy erejú földrengés pedig a föld színével tette egyenlővé az egykor ragyogó (splendida) colonia épületeit, melyek jó része már hosszú évtizedek óta amúgy is romosan, elhagyottan állott.

\section{IRODALOM}

Amm. Marc.

BAATZ, DIETWULF

1994 Die Handmühlen. In: Hellenkemper Salies, G.-von Prittwitz, H. H.-Bauchhens, Ga. und Ge. (Hrsg.): Das Wrack. Der antike Schiffsfund von Mahdia. Köln, 97-103.

BALÁZS PÉTER

2012 A savariai Iseum kútja. Ókor (Budapest) 2012/4, 69-75.

BALÁZs PÉTER-CSAPLÁRos ANDREA-SOSZTARITS OtTÓ (szerk.)

2013 Iseum. Isis temploma Szombathelyen. Sistrum. Serie B. 2. Szombathely.

BALLA LAJOS

1963 Savaria invalida. Megjegyzések a pannóniai városok Valentinianus-kori történetéhez (Savaria invalida. Notes to the History of the Pannonian Towns in the Time of Valentinian). Archaeologiai Értesító (Budapest) 90, 75-80.

BAKKER, JAN THEO (ed.)

1999 The Mills-bakeries of Ostia. Dutch Monographs on Ancient History and Archaeology Vol. XXI. Amsterdam.

BAlogh BeÁtA-Sosztarits OtTÓ-SZILAsi Attila Botond

2002 A Szombathely-Éva malom területén feltárt kora római falfestmény és topográfiai jelentősége. Savaria 25:3 (Szombathely) 2000-2001, 155-190.

BARTUS DÁVID-BORHY LÁSZLÓ-SZÁMADÓ EMESE

2015 Short Report on the Excavation in Brigetio 2015. Civil Town, canabae and Legionary Fortress. Dissertationes Archaeologicae ex Instituto Archaeologico Universitatis de Rolando Eötvös Nominatae (Budapest) 3, 245-262.

BíRÓ SZILVIA-SOSZTARITS OTTÓ

2013 Síregyüttesek és jellegzetes sírmellékletek. In: IsEUM KAT. 269-278.

BORHY, LÁSZLÓ

1996 Non castra sed horrea... Zur Bestimmung einer der Funktionen spätrömischer Binnenfestungen.

BRATOŽ, RAJKO

Bayerische Vorgeschichtsblätter (München) 61, 207-224.

1990 Die Geschichte des frühen Christentums im Gebiet zwischen Sirmium und Aquileia im Licht der neueren Forschungen. Klio. Beiträge zur alten Geschichte (Berlin) 72, 508-550.

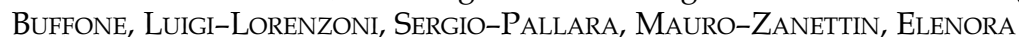

1999 Le macine rotatorie in rocce vulcaniche di Pompei. Rivista di Studi Pompeiani (Roma) 10, 117-130.

BuÓCZ TERÉZIA

1968 Savaria topográfiája. Szombathely.

1969 Szombathely-Bajcsy-Zsilinszky E. u. - Kisfaludy S. u. Régészeti Füzetek (Budapest) I/22, 33-34, No. 44.

= Archaeologiai Értesítő (Budapest) 96, 257, No. 44.

1991 A Járdányi Paulovics István Romkert helyreállítási és feltárási munkái (I-III. sz.). Savaria (Szombathely) 20:1, 13-26.

2003 Lapidarium - Savaria Múzeum. Szombathely.

CIL

Corpus Inscriptionum Latinarum

Chastagnol, ANDRÉ

1960 La préfecture urbaine à Rome sous le Bas-Empire. Paris.

CLEMENS, LUKAS

2001 Sankt Irminen: Römisches Wohnquartier, spätantike Speicheranlage (horrea) und frühmittelalterliche Klostersiedlung. In: Kuhnen, H.-P. (Hrsg.): Das römische Trier. Führer zu archäologischen Denkmälern 40. Stuttgart, 166-174. 
Croce Da Villa, Pierangela

2006 Considerationi sull'architectura degli horrea di Iulia Concordia. Quaderni di archeologia di Veneto 22, 212-224.

CSERMÉNYI VAJK

1980 Szombathely-Rákóczi F. u. 1. Régészeti Füzetek (Budapest) I/33, 50, No. 81/3. = Archaeologiai Értesító (Budapest) 107, 245, No. 37/2.

DEININGER, JÜRGEN

1965 Die Provinziallandtage der römischen Kaiserzeit von Augustus bis zum Ende des dritten Jahrhunderts n. Chr. München-Berlin

De LAET, SIEGFRIED J.

1949 Portorium. Étude sur l'organisation douanière chez les Romains, surtout à l'époque du Haut-Empire. Bruges.

DERDÁK FERENC-KISS GÁbOR

1994 Egy elfeledett szombathelyi sánc. Lapok Szombathely történetéból 25. Panniculus (Szombathely) C/32.

DOBÓ ÁRPÁD

1940 Publicum portorium Illyrici. Archaeologiai Értesítő (Budapest) 3, 144-194.

1968 Die Verwaltung der römischen Provinz Pannonien von Augustus bis Diocletianus. Die provinciale Verwaltung. Budapest.

1975 Inscriptiones extra fines Pannoniae Daciaeque repertae ad res earundem provinciarum pertinentes. Budapest.

ДИНЧЕВ, ВЕНЦИСЛАВ

2005 Къспоантични обществени складове от Thracia и Dacia (Late antique public granaries from Thracia and Dacia). In: Stephanos Archaeologicos in honorem Professoris Ludmili Getov. Studia Archaeologica Universitatis Serdicensis (Sofia) 4, 277-295.

$\mathrm{EDH}$

EIDEN, HANS

Epigraphische Datenbank, Heidelberg. http://edh-www.adw.uni-heidelberg.de/home (2017.04.01)

1949 Untersuchungen an den spätrömischen Horrea von St. Irminen in Trier. Mit einem Beitrag von Hermann Mylius. Trierer Zeitschrift (Trier) 18, 73-106.

ENSSLIN, YON W.

1930 Zum Heermeisteramt des spätrömischen Reiches. Die Titulatur der magistri militum bis auf Theodosius I. Klio. Beiträge zur alten Geschichte (Leipzich) 23, 306-325.

1931 Zum Heermeisteramt des spätrömischen Reiches. Klio. Beiträge zur alten Geschichte (Leipzich) 24, 1931, 102-147.

1954 Praefectus praetorio. In: PWRE 44, 2432.

FIECHTER, ERNST ROBERT

1913 Horreum. In Pauly's Realencyclopädie der Classischen Altertumswissenschaft (Stuttgart) VIII.2, 24582464.

FHG

GÖMÖRI, JÁNOS

Fragmenta Historicorum Graecorum

2003 Scarbantia. In: Šašel Kos, M.- Scherrer, P. (Hrsg.): The Autonomous Towns of Noricum and Pannonia Die autonomen Städte in Noricum und Pannonien. Pannonia I. Situla (Ljubljana) 41, 81-92.

2013 Scarbantia maradványai a soproni Fő téren és környékén. Régészeti kutatások 1971 és 2003 között. In: Szentesi E.-Mentényi K.-Simon A. (szerk.): Kő kövön. Stein auf Stein. Dávid Ferenc 73. születésnapjára. Festschrift für Ferenc Dávid. h. n., 213-224.

GRAF, ANDREAS

1936 Übersicht der antiken Geographie von Pannonien. Dissertationes Pannonicae. I:2, Budapest.

GUTSFELD, ANDREAS

2001 Praefectus praetorio. In: Cancik, H.-Schneider H. (Hrsg.): Der Neue Pauly. Enzyklopädie der Antike. Altertum. Band 10, Pol-Sal. Stuttgart.

HAJNÓCZI GYULA

1987 Pannónia római romjai. Budapest.

HajNÓCZI GYUla-MEZós TAMÁs

1995 Pannonia Hungarica Antiqua. Budapest.

HAUG, ANETTE

2003 Die Stadt als Lebensraum. Eine kulturhistorische Analyse zum spätantiken Stadtleben in Norditalien. Internationale Archäologie 85. Rahden/Westf.

2012 Die Stadt als Repräsentationsraum. Rom und Mailand im 4. Jh. n. Chr. In: Fuhrer, Th. (Hrsg.): Rom und Mailand in der Spätantike. Repräsentationen städtischer Räume in Literatur, Architektur und Kunst. Topoi-Berlin Studies of Ancient World 4. Berlin-Boston, 111-136. 
HEINRICH-TAMÁSKA, ORSOLYA

2013 Die spätrömische Innenbefestigung von Keszthely-Fenékpuszta: Innere Chronologie und Funktioneller Wandel. In: Heinrich-Tamáska, O. (Hrsg.): Keszthely-Fenékpuszta im Kontext spätantiker Kontinuitätsforschung zwischen Noricum und Moesia. Castellum Pannonicum Pelsonense 2. BudapestLeipzig-Keszthely-Rahden Westf., 653-702.

Hódi ATTILA

2015 Ki önt fel a garatra? Római malomtöredékek Savariából. In: Tanai I. (szerk.): MúTárgyEsetek I. Szombathely, 50-56.

HOLL, KARL

1915 Griechische christliche Schriftsteller. Berlin

ILS

1892-1916 Dessau, Hermann: Inscriptiones Latinae Selectae. Berlin.

ISEUM KAT.

2013 Sosztarits O.-Balázs P.-Csapláros A. (szerk.) A savariai Isis szentély I. Isis savariai otthona - kiállítási katalógus. Sistrum Serie A. 1., Szombathely.

IsZTIN GYULA-TÁRCZY TAMÁs-TÓTH ENDRE

2013 A savariai császári palota és díszterme (Der Kaiserpalast von Savaria und sein Prunksaal). Savaria (Szombathely) 36, 187-201.

JEREMIĆ, MiROSLAV

1993a Granary (horrea), Baths (thermae) and Southwall. In: Srejović, D. (ed.): Roman Imperial Towns and Palaces in Serbia. Belgrade, 100-103.

1993b Public Granaries (Horrea publica). In: Srejović, D. (ed.): Roman Imperial Towns and Palaces in Serbia. Belgrade, 113-114.

KÁROLYi ANTAL-SZENTLÉLEKy TiHAMÉR

1967 Szombathely városképei - múemlékei. Budapest.

KÁRPÁTI KELEMEN

1894 Sabariai régiségek. Archaeologiai Értesítő (Budapest) 14, 448-450.

Kiss GÁbor-Tóth ENDRE-ZÁGORHIDI CZIGÁNy BALÁZS

1998 Savaria-Szombathely története a város alapításától 1526-ig. Szombathely.

KORNEMANN, ERNST

1900 Concilium. In: PWRE 4, 808.

KORNISS EMIL

1901a Emil in Vas I. évf. 17. sz. (1901. május 9.), 3.

1901b Vasvármegye 34. évf. No. 66 (1901. június 5.), 4.

KOVÁCs PÉTER

2011 Fontes Pannoniae antiquae in aetate tetrarcharum I (A. D. 285-305). Az ókori Pannonia forrásai az első tetrachia korában (Kr. u. 285-305). Budapest.

KOVALICZKY GERGELY-Tóth ZsOLT

2014 Pécs római kori településének vázlata. Ókor (Budapest) 2014:1, 81-91.

KUBITSCHEK, WILHELM

1899 Carnuntum. In: PWRE III. 1605.

LAPSAV

2011 E. Tóth, Lapidarium Savariense. Savaria római feliratos kőemlékei. Savaria 34/2, 2011.

LipP VILMOS

1870 Szombathelyi közlemények V. Archaeologiai Értesítő (Budapest) 3, 43-46.

1872a Vasmegyei Lapok (Szombathely) VII. No. 80. (1872. október 6.)

1872b Hírek. Archaeologiai Értesítő (Budapest) 7, 103.

LOLIĆ, TATJANA

2003 Colonia Flavia Siscia. In: Šašel Kos, M.-Scherrer, P. (Hrsg.): The Autonomous Towns of Noricum and Pannonia - Die autonomen Städte in Noricum und Pannonien. Pannonia I. Situla (Ljubljana) 41, 131152.

LUIK, MARTIN

2001 Römische Wirtschaftsmetropole Trier. Tierer Zeitschrift (Trier) 64, 245-282.

MAZZARINO, SANTO

1951 Aspetti sociali del quarto secolo. Roma

Medgyes MAgdolnA

1991 Szombathely-Mátyás király u. Régészeti Füzetek (Budapest) I/43, 30, No. 48.

1997 Savaria településszerkezete és városfala az újabb kutatások tükrében. Lapok Szombathely történetéből. Panniculus (Szombathely) Ser. C. No. 70.

1998 The Settlement Structure and Town Walls of Savaria as Reflected by the Latest Excavations. In: Németh, M. (ed.): The Roman Town in a Modern City. Aquincum Nostrum II. Budapest, 87-91. 
MigL, JOACHIM

1994 Die Ordnung der Ämter. Prätorianerpräfektur und Vikariat in der Regionalverwaltung des Römischen Reiches von Konstantin bis zur Valentinianischen Dynastie. Europäische Hochschulschriften Reihe 3, Geschichte und ihre Hilfswissenschaften 623 (Frankfurt).

Mirabella Roberti, Mario

1965 L'edificio romano nel 'Patriarcato' - Horrea die Aquileia. Aquileia Nostra (Aquileia) 36, 45-71.

MirKović, MirosLaV

2004 Sirmium. In: Šašel Kos, M.-Scherrer, P. (Hrsg.): The Autonomous Towns of Noricum and Pannonia - Die

MitTHOF, FRITZ autonomen Städte in Noricum und Pannonien. Pannonia II. Situla (Ljubljana) 42, 145-156.

2001 Annona Militaris. Die Heeresversorgung im spätantiken Ägypten. Ein Beitrag zur Heeresgeschichte des römischen Reiches im 3. bis 6. Jh. n.Chr. Papyrologica Florentina 32. Firenze.

MLADONICZKI RÉKA-SOSZTARITS OTTÓ

2009 Die Strecke der Bernsteinstraße in Savaria. In: Sz. Bíró (Hrsg.): Ex officina... Studia in honorem Dénes Gabler. Győr, 325-357.

MÓCSY, ANDRÁS

1962 Pannonia. In: PWRE Supl. IX, 516-776, Stuttgart.

1981 Die spätrömische Festung. In: Mócsy A. (Hrsg.): Die spätrömische Festung und das Gräberfeld von Tokod. Budapest, 37-71.

Mócsy ANDRÁS-FITZ JENő (szerk.)

1990 Pannonia régészeti kézikönyve. Budapest.

MOREAU, JACQUES

1961 Die Christenverfolgung im römischen Reich. Berlin.

NAGY TiBOR

1939 A pannoniai kereszténység története a római védőrendszer összeomlásáig. Dissertationes Pannonicae II:12, Budapest.

1943 Sopianae. Une cité antique de la Pannonie. Société de la Nouvelle Revue de Hongrie. Budapest, 495-503.

1954 A pannoniai városok élete a korai feudalizmusban. MTA II. Osztály Közleményei 5, 1954, 510-519.

1964 Révision de 1'inscription d' un autel d' Hercule de Buda. Acta Antiqua Hungarica (Budapest) 12, 207215.

1975 Budapest története az őskortól a honfoglalásig. Budapest története I. Az őskortól az Árpád-kor végéig. Szerk.: Gerevich L. Budapest, 39-216.

1987-88 Sopianae. Egy új városmonográfia margójára. Antik Tanulmányok (Budapest) 33, 218-245.

[2017] Kézirat: Savaria IV. századi történetének kérdései. Jelen tanulmány függeléke.

Nemeth-Ehrlich, Dorica-Kusan Spalj, Dora

2003 Municipium Andautonia. In: Šašel Kos, M.-Scherrer, P. (Hrsg.): The Autonomous Towns of Noricum and Pannonia - Die autonomen Städte in Noricum und Pannonien. Pannonia I. Situla (Ljubljana) 41, 107-129.

NesselHauf, HeRBERT

1938 Die spätrömische Verwaltung der gallisch-germanischen Länder. Berlin.

Not. Dign. Occ. Or.

Notitia dignitatum et administrationum omnium tam civilium quam militarium. Imperum romanum

ORTH, FERDINAND occidentalis. Imperium romanum Orientalis.

1912 Granarium. In Pauly's Realencyclopädie der Classischen Altertumswissenschaft (Stuttgart) VII.2, 18121813.

PALANQUE, JEAN-RÉMY

1933 La préfecture du prétoire du Bas-Empire. Bruxelles.

PAVAN, MASsimiliano

1955 La provincia romana della Pannonia Superior. Roma.

PEACOCK, DAVID

1989 The Mills of Pompeii. Antiquity 63, Issue 239, 205-214.

2013 The Stone of Life. The Archaeology of Querns, Mills and Flour Production in Europe up to c. AD 500.

Southampton Monographs in Archaeology New series 1, Southampton.

PEKÁRY TAMÁS

1953 Aquincum pénzforgalma. Archaeologai Értesítő (Budapest) 80, 114-153.

PLRE

1971 Jones, A. H. M.-Martindale, J. R.-Moris, J.: Prosopography of the Later Roman Empire. 1. A. D. 260-395.

Cambridge. 
PÓCZY KLÁRA

1967 Scarbantia városfalának korhatározása (La datation de l'evidence de Scarbantia). Archaeologiai Értesítő (Budapest) 94, 137-154.

POMPEJI KAT.

2016 Gabler D. (szerk.): Pompeji. Élet és halál a Vezúv árnyékában. A Móra Ferenc Múzeum kiállításának vezetője. Szeged.

PopOVIĆ, VLADISLAV

1993 Sirmium - a Town of Emperors and Martyrs. In: Srejović D. (ed.): Roman Imperial Towns and Palaces in Serbia. Belgrade, 15-27.

POPOVIĆ, IVANA

2013 Sirmium - Imperial Residence, Pannonian Metropolis and Christian „Head of Illyricum”. In: Popović, I.- Borić-Brešković B. (eds): Constantine the Great and the Edict of Milan 313. Belgrade, 102-117.

PORTMANN, W.

2001 Vulcacius Rufinus. In: Cancik, H.-Schneider H. (Hrsg.): Der Neue Pauly. Enzyklopädie der Antike. Altertum. Band 10, Pol-Sal. Stuttgart, 1153-1154.

POULTER, ANDREW

1992 The Use and Abuse of Urbanism in the Danubian Provinces during the Later Roman Empire. In: Ridge,

PWRE J. (ed.): The City in the Late Antiquity. London-New York, 99-185.

RADNÓTI ALADÁR

Pauly-Wissowa Realencyclopädie der classischen Altertumswissenschaft.

1954 Pannoniai városok élete a korai feudalizmusban, MTA II. Osztály Közleményei. Budapest.

REIDINGER, WALTER

1956 Die Statthalter des ungeteilten Pannonien und Oberpannoniens von Augustus bis Diocletian. Antiquitas, Reihe 1. Abhandlungen zur alten Geschichte, Bd. 2. Bonn.

RICKMAN, GEOFFREY

1971 Roman Granaries and Store Buildings. Cambridge.

RIU I.

1972 Barkóczy, László-Mócsy, András: Die römischen Inschriften Ungarns. Savaria, Scarbantia und die Limes-Strecke Ad Flexum - Arrabona.

Rizos, EFTHYMios

2013 Centres of the late Roman Military Supply Network in the Balkans: a Survey of horrea. Jahrbuch des Römisch-Germanischen Zentralmuseums (Mainz) 60, 659-696.

SALIDO DOMÍNGUEZ, JAVIER

2011 Horrea militaria. El aprovisionamiento de grano al Ejército en el Occidente del Imperio Romano. Anejos de Gladius 14. Madrid.

SARIA, BALDUIN

1951 Poetovio. In: PWRE XXI. Stuttgart.

SEECK, ОTTO

1876 Notitia dignitatum. Accedunt Notitia urbis Constantinopolitanae et laterculi Prouinciarum. Berlin.

1897 Geschichte des Untergangs der antiken Welt. I-VI. Berlin.

1906 Die Briefe des Libanios. Leipzig.

1914 Discussor. In: PWRE 5.1.1183-1187.

SKRIBA PÉTER-KISS PÉTER

2007 Szombathely, Rákóczi Ferenc utca 3. Régészeti Kutatások Magyarországon (Budapest), 288, No. 341.

SOPRONI SÁNDOR

1978 Der spätrömische Limes zwischen Esztergom und Szentendre. Budapest.

SOSZTARITS OTTÓ

1994 Topographische Forschungen im südlichen Teil von Savaria. In: La Pannonia e l'Impero Romano.

Annuario dell'Accademia d'Ungheria. Roma, 233-241.

2010 Evidencen der Chronologie vom Iseum in Savaria. In: Győry, H. (ed.): Agyptus et Pannonia. Acta Symposii anno 2006. (Budapest) 4, 145-154.

2016 Az Iseum Savariense és a pogányság végnapjai Savariában. In: Tóth E.-Vida T.-Takács I. (szerk.): Szent Márton és Pannonia. Kereszténység a római világ határán. Pannonhalma-Szombathely, 35-42.

SOSZTARits OtTÓ-BALÁzs PÉTER

2017 Die neuzeitliche Geschichte des Iseum Savariense. In: Győry, H. (ed.): Agyptus et Pannonia (Budapest) 6, 165-176.

STEIN, ERNST-PALANQUE, JEAN-RÉMY

1959 Histoire du Bas-Empire Tom I. De l'État Romain à l'État Byzantin, Paris.

SWOBODA, ERICH

1953 Carnuntum. Seine Geschichte und seine Denkmäler. Graz-Köln. 
SZABó MiKLÓs-Borhy LÁSZló

2015 Magyarország története az ókorban: Kelták és rómaiak. Budapest.

SZENTLÉLEKY TIHAMÉR

1960 Szombathely-Thököly u. 14-18. Régészeti Füzetek (Budapest) I/13, 51-52. = Archaeologiai Értesítő (Budapest) 87, 235.

1966 Szombathely-Rákóczi F. u. 7. Régészeti Füzetek (Budapest) I/19, 28 Nr. 38. = Archaeologiai Értesítő (Budapest) 93, 296, Nr. 38.

1969 Szombathely-Rákóczi F. u. 8-10. Régészeti Füzetek (Budapest) I/22, 34, Nr. 44. = Archaeologiai Értesító (Budapest) 96, 257, Nr. 44.

SZENTLÉLEKY TIHAMÉR-CSERMÉNYI VAJK

1979 Szombathely-Rákóczi F. u. 1. Régészeti Füzetek (Budapest) I/32, 57-58, Nr. 85/2. = Archaeologiai Értesítő (Budapest) 106, 281, Nr. 43.

TAlabér TÜnde-Tóth MELINDA

1999 Vas vármegye régészeti hírei a napi sajtóban 1900-1904. Panniculus Ser. B. 4. Szombathely. THOMAS, G. S. R.

1979 Remarks on a possible criobolium site in Savaria. Numen. International Review for the History of Religion (Leiden) 26:2, 231-233.

TÓTH ISTVÁN

1975 IV. századi áldozóhely nyomai a savariai Iseum mellett. Archaeologiai Értesítő (Budapest) 102, 46-51.

TÓTH ENDRE

1971 Savaria insularendszerének rekonstrukciója. (Rekonstruktion des Insula-System in Savaria). Archaeologiai Értesítő (Budapest) 98, 143-169.

1973 Late Antique Imperial Palace in Savaria. The Question of the So-called Quirinus Basilica. Acta Archaeologica Scientiarum Hungaricae (Budapest) 25, 117-137.

1976 Der Mosaikfussboden der Aula Palatina von Savaria. Acta Archaeologica Scientiarum Hungaricae (Budapest) 28, 301-317.

2001 A császárkultusz főoltára Pannonia Superiorban (Der Hauptaltar des Kaiserkultes in Pannonia Superior). Archaeologiai Értesítő (Budapest) 128, 5-33.

2009 Studia Valeriana. Az alsóhetényi és ságvári késő római erődök kutatásának eredményei. Dombóvár.

2011 Die spätrömische Palastanlage von Savaria (Pannonia superior). In: v. Bülow, G.- Zabehlicky, H. (Hrsg.): Bruckneudorf und Gamzigrad. Spätantike Paläste und Großvillen im Donau-Balkan-Raum. Akten des Internationalen Kolloquiums in Bruckneudorf vom 15. bis 18. Oktober 2008. Bonn, 275-284.

2016 Savaria Szent Márton korában. In: Tóth E.-Vida T.-Takács I. (szerk.): Szent Márton és Pannonia. Kereszténység a római világ határán. Pannonhalma-Szombathely, 174.

TóTH ZsolT

2009 Kutatások Pécs belvárosában 1. Római kori bazilika. http://sirasok.blog.hu/2009/06/15/uj_kutatasok_ pecs_belvarosaban_1_sophianae_romai_bazilikaja (2017.05.08)

2010 Adatok Pécs római kori történetéhez. Összefoglaló a Rákóczi út-Jókai utca saroktelken végzett 20082009. évi régészeti feltárásról. Ókor (Budapest) IX. 3, 102-109.

VÁRADY LÁSZLÓ

1961 Későrómai hadügyek és társadalmi alapjaik. A Római Birodalom utolsó évszázada (376-476). Budapest.

VISY ZSOLT

2013 Sopianae településtörténete. In: Vonyó J. (szerk.): Pécs története I. Az őskortól a püspökség alapításáig. WHATELY, CONOR Pécs, 93-152.

2013 War in Late Antiquity: Secondary Works, Literary Sources and Material Evidence. In: Sarantis, A.Christie, N. (eds): War and Warfare in Late Antiquity. Leiden-Boston, 101-152.

\title{
HORREA UND DENKMÄLER DER GETREIDEVERARBEITUNG IN SAVARIA
}

\author{
PÉTer Balázs-Szilvia Bíró-Andrea Csapláros-Attila Hódi-OtTó Sosztarits
}

Für die Getreideversorgung des Militärs (annona militaris) von Savaria und der pannonischen Provinzen ist eine Bauinschrift (CIL III 4180=RIU I 48 = LAPSAV 63-65 Nr. 8.) besonders wichtig, welche im Zuge der Errichtung eines Horreums in Savaria von C. Vulcacius Rufinus praefectus praetorio gestiftet wurde. Diese Marmortafel erregte das Interesse der internationalen Forschung, in der ungari- schen Literatur hingegen- mit Ausnahme des Aufsatzes von Tibor Nagy in diesem Band - bekam sie nicht die notwendige Aufmerksamkeit.

Bei der Deutung dieser Inschrift müssen wir uns mit der Frage der Getreideversorgung in den spätrömischen Provinzen, den noch sichtbaren Gebäuderesten und dem auf der Bauinschrift erwähnten horreum im Zusammen- 
hang mit noch erhaltenen Gebäuderesten beschäftigen. Für die Arbeiten an diesem Thema kamen zwei archäologisch teilweise erforschte Gebäude aufgrund ihrer Bautechnik (z. B. stärkere Mauern, gemischte Mauertechnik, Pfeiler oder Stützpfeiler) in Betracht. Ein Gebäude im östlichen Bereich außerhalb von Savaria (heute Kisfaludy-Straße) kann man nur bedingt als horreum bezeichnen. Im Gegensatz dazu kann man das Gebäude im südlichen Bereich außerhalb der Stadt in direkter Nachbarschaft zum Iseum, das zwischen 19781979 von Tihamér Szentléleky und Vajk Cserményi bzw. zwischen 2013-2015 von den Autoren dieses Aufsatzes teilweise ergraben wurde, mit großer Wahrscheinlichkeit als granarium bezeichnen. Dieses Gebäude wurde meistens mit dem Baumaterial des abgerissenen IsisHeiligtums errichtet; diese Bautätigkeiten gehörten möglicherweise zu den letzten öffentlichen Bautätigkeiten in Savaria. So können wir eindeutig ausschließen, dass die auf der zwischen 344-347 zu datierenden RufinusInschrift erwähnten horrea mit diesem Gebäude in Zusammenhang stehen. Wenn wir die topographischen Lagen der horrea von Savaria mit den bekannten horrea in anderen römischen Verwaltungszentren vergleichen, ist auffällig, dass die horrea in diesen Städten innerhalb der Stadtmauern, sowie meist in der Nähe eines Stadttores und an der Hauptstraße lagen; die horrea von Savaria aber lagen zwar an den Straßen, aber außerhalb der Stadtmauer. Die in Savaria entdeckten Gebäudetypen zeigen ähnliche Züge wie die horrea der Binnenstädte und -festungen, aufgrund der Größe und Bauausführung erreichen sie aber nicht dasselbe Niveau wie vergleichbare Gebäude in Städten mit Statthaltersitz (wie z. B. Aquileia, Sirmium und Augusta Treverorum) innerhalb des Römischen Reichs.

In der Umgebung des südlichen Horreums wurden aus Basalttuff gefertigte Mühlsteinfragmente vom Typus Pompei entdeckt. Die Funde sind nördlich der Alpen sehr selten und als spektakulär zu bezeichnen. Die Funde wurden um die Mitte des 2. Jhs. und in die erste Hälfte des 3. Jhs. in die Erde gekommen. Aufgrund der Datierung kann man diese Mühlsteine zwar mit einem industriellen Mühlvorgang verbinden, sie stehen aber nicht im Zusammenhang mit den bekannten horrea von Savaria.

Es ist seit langem bekannt, dass sich Valentinian I. mitsamt seinem Hofstaat und seiner militärischen Begleitung im Jahre 375 in Savaria aufhielt. Die zeitliche Nähe dieses Besuches mit der Errichtung des südlichen Horreums lässt eine Verbindung zwischen diesen beiden Ereignissen vermuten. Diese Theorie ist bis dato nur hypothetisch, die bislang bekannten archäologischen Tatsachen unterstützen diesen Gedanken, beweisen ihn aber nicht. Zusammenfassend müssen wir festhalten, dass die auf der Bauinschrift von Vulcacius Rufinus erwähnten und für das Römische Reich oder für die Provinz bedeutenden horrea bislang zu den nicht mit letzter Sicherheit lokalisierten Gebäuden in Savaria zählen. 